\title{
É assim, porque é assim que tem que ser: a retórica galante nos motetes de José Maurício, observada no uso da pedagogia dos partimenti, da gramática das schemata e da oratória musical
}

\author{
It is as it is, because this is how it should be: galant rhetoric in José \\ Mauricio's motets, observed within the use of partimenti pedagogy, \\ schemata grammar, and musical oratory
}

\author{
Diósnio Machado Neto \\ Fernando Tavares \\ Rodrigo Lopes da Silva \\ Gustavo Caum e Silva \\ Universidade de São Paulo
}

\begin{abstract}
Resumo: A música no universo galante tinha como teleologia objetivar processos sociocomunicativos através da experiência compartilhada de figuras musicais, campos expressivos, esquemas harmônicos (contrapontísticos) e modelos dramáticos transformados em oratória musical (onde a forma se inclui). Estes parâmetros se desdobravam por uma técnica composicional onde cada elemento estava devidamente articulado com uma ideia a se expressar; ou seja, cada elemento tinha uma função e objetivo dentro da estrutura. Assim, frases e cadências, campos expressivos e figuras de retórica, existiam sempre numa relação das partes com o todo. Era o que, na música, se desprendia do esforço de se alinhar a uma ideia hegemônica nos círculos cultos setecentistas: uma lógica de invenção pelo princípio da Ars Combinatória de Leibnitz. O presente texto trata de mostrar, primeiro, como a regência desse processo se dava sob uma mentalidade cognitiva operada pela ideia de Retórica Musical. Segundo, como era assimilada e operacionalizada como pedagogia, processo criativo e expressão ideológica, enquanto discurso musical. Para tanto, usaremos excertos de motetes do compositor carioca José Maurício Nunes Garcia (1767-1830) para decantar vários elementos expressivos relacionando-os com modelos aprendidos através da pedagogia dos partimenti e, também, dos processos combinatórios dos esquemas retóricos para construção de pictorialismos naturais da escrita motetistica. Neste sentido, o estudo mostra como
\end{abstract}


MUSICA THEORICA Revista da Associação Brasileira de Teoria e Análise Musical 2020, v. 5, n. 2, p. 74-141 - Journal of the Brazilian Society for Music Theory and Analysis@ TeMA 2020 - ISSN 2525-5541

tonalidades, cadências, harmonia, schemata e métricas estão articuladas como processos oratóriais que interpretamos ser a ideia de redenção. O texto, diga-se, apresenta resultados de uma linha de pesquisa desenvolvida no Laboratório de Musicologia da EACH-USP sobre processos discursivos na música de José Maurício. Segue a tese das representações de valores e crenças que, metaforizados em música, se alinham com estruturas ideológicas de controle no exercício do espetáculo litúrgico nos domínios luso-brasileiros.

Palavras-chave: Retórica Musical. José Maurício Nunes Garcia. Partimenti e Schemata. Música no Brasil Colonial.

Abstract: Music in the gallant universe had as teleology objectify process sociocommunicative through the shared experience of musical figures, expressive fields, harmonic schemes (contrapuntal), and dramatic models transformed into musical oratory (where the form is included). These parameters were unfolded by a compositional technique where each element was duly articulated with an idea to express; that is, each element had a function and objective within the structure. Thus, phrases and cadences, expressive fields, and rhetoric figures always existed in a relationship between the parts and the whole. It was, in music, what was released from the effort to align itself with a hegemonic idea in refined circles of the 18th century: a logic of invention by the principle of Leibnitz's Ars Combinatória. The present text tries to show, first, how the conduct of this process took place under a cognitive mentality operated by the idea of Musical Rhetoric. Second, how it was assimilated and operationalized as pedagogy, creative process, and ideological expression, as a musical discourse. For this purpose, we will use extracts of motets by the Rio de Janeiro composer José Maurício Nunes Garcia (1767-1830) to decant several expressive elements relating them to models learned through the pedagogy of partimenti and, also, of the combinatórial processes of rhetorical schemes for the construction of pictorialisms, natural of the motetistic writing. In this sense, the study shows how tonalities, cadences, harmony, schemata, and metrics are articulated as oral processes that we interpret as the idea of redemption. The text, it should be said, presents the results of a line of research developed at the Musicology Laboratory of EACH-USP on discursive processes in José Maurício's music. It follows the thesis of representations of values and beliefs that, metaphorized as music, align with ideological structures of control in the exercise of the liturgical spectacle in the Luso-Brazilian domains.

Keywords: Musical Rhetoric. José Maurício Nunes Garcia. Partimenti and Schemata. Music in Colonial Brazil. 
É assim, porque é assim que tem que ser: a retórica galante nos motetes de José Maurício, observada no uso da pedagogia dos partimenti, da gramática das schemata e da oratória musical

\section{Considerações iniciais: uma breve justificativa para uma musicologia histórico-analítica}

O esforço de três gerações de pesquisadores dedicados à prática e escrita da música no Brasil colonial esteve bravamente dedicado a inventariar documentos sobre a atividade musical, organizar e catalogar partituras e, mais recentemente, discutir questões editoriais. No decorrer de 60 anos, desde as ações de Curt Lange, um esforço coletivo entre musicólogos, intérpretes e historiadores de diversas especialidades desvelou um rico repertório, canonizou agentes numa história da música no Brasil, editou obras, produziu um bom acervo fonográfico, discutiu paradigmas histórico-sociais sobre a organização e circulação dos músicos e das músicas, e tornou todo esse conhecimento uma disciplina para a formação acadêmica.

Desde Curt Lange, passando por Régis Duprat, Cleofe Person de Mattos, Jaime Diniz, José Maria Neves, entre outros, até chegarmos na estruturação de linhas de pesquisa nos diversos programas de pós-graduação, assim como por projetos de grande porte, como o do Museu da Música de Mariana e do Acervo do Cabido do Rio de Janeiro, a jornada foi intensa e obteve consideráveis conquistas. Hoje, pode-se dizer que esse intenso trabalho se confunde com o que entendemos como musicologia no Brasil.

Esse cenário é fácil de ser averiguado quando observamos como se dá a presença brasileira nos eventos, nas associações e nos grupos de estudos que têm na música antiga um espaço de acolhimento. Na senda dos trabalhos sobre acervos e questões da organização social da prática musical, os musicólogos brasileiros, hoje, estão bem-posicionados em muitas frentes. Temos uma boa representação nos Projetos Rs (RIdIM, RILM, RIPM, RISM) e em associações como a IAML (International Association of Music Libraries, Archives and Documentation Centres). Associações como a IMS (International Musicological Society) e seu braço latino-americano, a ARLAC (Asociación Regional para América Latina y el Caribe), assim como grupos interinstitucionais, como o Núcleo Caravelas (com sedes no CESEM/Universidade Nova de Lisboa e na Universidade Federal do Rio de Janeiro), registram informes de pesquisa e participação em grupos de estudos onde o tema é a música antiga no Brasil. Alguns congressos em território brasileiro tornaram-se ponto de intercâmbio internacional, como o Simpósio Internacional de Musicologia do EMAC/UFG e o Simpósio Internacional de Música Ibero-americana da Universidade Estadual 
MUSICA THEORICA Revista da Associação Brasileira de Teoria e Análise Musical 2020, v. 5, n. 2, p. 74-141 - Journal of the Brazilian Society for Music Theory and Analysis@ TeMA 2020 - ISSN 2525-5541

do Amazonas. Contamos, inclusive, com grupos musicais especializados nesse espaço, como a Orquestra Barroca do Amazonas (dirigida por Márcio Páscoa), a Américantiga Ensemble (dirigida por Ricardo Bernardes), e corais como o Ensemble Turicum (dirigido por Luiz Alves da Silva).

No entanto, há um campo que só recentemente mostra-se mais dinâmico. Trata-se dos estudos sobre o processo criativo em face da recepção teórica no território luso-brasileiro, ou seja, de uma análise dessa música a partir de uma perspectiva historicamente informada. Desde os estudos iniciais de Régis Duprat, Maurício Dottori, Carlos Kater, entre outros, ${ }^{1}$ vemos que somente nesta década intensificamos o interesse nesse campo. Mesmo que pontuais, há pesquisas em desenvolvimento usando documentos e partituras luso-brasileiras que tratam desde questões de fundamentos teóricos, como saberes para a realização de Baixo Contínuo, até estudos sobre significação musical, notadamente sobre Retórica Musical. Alguns centros se destacam por organizar linhas com produção constante, como o Laboratório de Musicologia e História Cultural da Universidade Estadual do Amazonas e o Laboratório de Musicologia

\footnotetext{
${ }^{1}$ Um dos primeiros textos sobre questões da recepção teórica é de Régis Duprat, Música Sacra Paulista no Período Colonial: alguns aspectos de sua evolução tonal - 1774/1794 (1990). Nessa mesma época surgiram outros textos na mesma direção, inclusive uma publicação de um periódico que tratava especificamente de análise. Trata-se do Caderno de Estudo: Análise Musical, editado por Carlos Kater, a partir de 1989. Assim como Duprat, Kater também busca uma síntese estilística da música antiga em Análise e Música Brasileira dos séculos XVIII e XIX (1994). Outros textos compõem essa tendência, como o de Sílvio Crespo, O Hino a 4 de Marcos Coelho Neto, (1990) e o de Maurício Dottori, A Estrutura Tonal na Música de João de Deus de Castro Lobo (1990). Porém, como Machado Neto (2011, p.199) afirma "a postura analítica era decorrente de uma hegemonia do pensamento funcional da harmonia. É um pensamento coletivo que se expressa. Por muitos relatos e anotações de aula desse tempo, nota-se que não havia uma abertura a outras possibilidades de ensino e análise. A musicologia analítica internacional dessa época já descortinava inúmeros problemas composicionais do século XVIII: as hibridações modais da formação harmônica e sua herança dentro do sistema hexacordal, inclusive vinculadas a toda uma problemática de construção discursiva presa às estruturas que recobravam da retórica suas leis dialéticas (arte do equilíbrio das partes)." Dito isso, destacamos o trabalho de Maurício Dottori, que na mesma época dos textos supracitados, observa outros caminhos para a análise da música antiga no Brasil. Em Ut Rhetorica Musica: análise do moteto O Vos Omnes a dois coros, de Manoel Dias de Oliveira (1992), Dottori observou questões analíticas sob uma perspectiva de conceitos discursivos retóricos. No entanto, esse texto não se desdobrou em um projeto de pesquisa que produzisse maiores impactos na musicologia nacional. Esta se manteve fiel às suas bases paradigmáticas mais tradicionais, especificamente amparadas na Formenlehre schoenberguiana. Somente a partir da década de 2000 começaram a surgir textos mais atentos à questão da relação do processo criativo com os problemas da formação musical dos músicos setecentista.
} 
É assim, porque é assim que tem que ser: a retórica galante nos motetes de José Maurício, observada no uso da pedagogia dos partimenti, da gramática das schemata e da oratória musical

da EACH-USP. Da mesma forma, é notório o crescimento de estudos individuais sobre o tema. ${ }^{2}$ E, recentemente, esse esforço foi, de certo modo, reconhecido em publicações importantes para o universo ibero-americano, como é o caso do livro de Rubén López-Cano, La Música Cuenta: Retórica, Narratividad, Dramaturgía, Cuerpo y Afectos (2020, p. 258).

Dito isso, este artigo surge na senda de continuarmos a discussão sobre a circulação de saberes e suas aplicações, assim como para dar aportes de como funcionavam ferramentas pedagógicas dentro do processo criativo dos compositores estabelecidos, como no caso de José Maurício Nunes Garcia (17671830). Neste texto, nosso objetivo geral articula alguns pontos dentro de uma única causa: o pensamento retórico expresso no processo criativo. Assim, esse artigo pretende expor:

Como o processo criativo estava amparado num princípio de organização retórica, amparada por um treinamento de ars combinatória, e ciente das leis de uma oratória musical;

Mostrar como uma pedagogia de treinamento prático-pedagogia dos partimenti-, cujo fundamento era reconhecer e utilizar padrões harmônicos

\footnotetext{
2 Aqui, destacamos alguns textos, a começar com os produzidos no âmbito do Laboratório de Musicologia da EACH-USP: Diósnio Machado Neto, $A$ arte do bem morrer: $O$ discurso tópico na Sinfonia Fúnebre de José Maurício Nunes Garcia (2017); Idem, E jazerá em jardim florido: estudo preliminar sobre usos tópicos na representação da Mariologia na música de José Maurício Nunes Garcia (2019); Ágata Yozhiyoka Almeida e Diósnio Machado Neto, A interação de tópicas musicais e schemata galantes na Missa de Réquiem (1816) de Marcos Portugal (2020); Ozório Christovam e Diósnio Machado Neto, Estratégias comunicativas na música sacra de André da Silva Gomes: retórica, tópicas, partimento e esquemas musicais (2019); Ozório Christovam, Música Sacra, Discurso e Poder: Modelos Pré-Composicionais na Missa Luso-Brasileira (2018. Tese/Doutorado em Musicologia - ECAUSP); Rafael Registro Ramos, Discurso e Conceitos no Tratado de Contraponto de André da Silva Gomes: Um Estudo de Recepção (2011. Dissertação/Mestrado em Musicologia - ECA-USP). No mesmo sentido, vemos produções do Laboratório de Musicologia e História Cultural da Universidade Estadual do Amazonas: Márcio Páscoa, O quanto é preciosa ao Compositor a Instrução Literária?: o projeto criativo em Arte explicada do contraponto de André da Silva Gomes (1752-1844); Andrés Florentino e Mário Marques Trilha, Análise do segundo movimento do segundo concerto para clarinete e orquestra, de José Avelino Canongia, através dos passos do discurso retórico e análises de esquemas de contraponto (2020); Guilherme Monteiro, Análise Tópica de Schemata e Elementos Retórico-Musicais em Seis Responsórios Fúnebres de João de Deus de Castro Lobo (1794-1832) (2020. Dissertação/Mestrado em Mestrado em Letras e Artes - Universidade Estadual do Amazonas). Destacamos, ainda, os textos de Ernesto Hertmann, O uso da Schemata na construção da Abertura Zemira (1803) do Padre José Maurício Nunes Garcia (2019); A Sinfonia Fúnebre (1790) do Padre José Maurício Nunes Garcia (1767-1830): análise com o conceito de Schema Musical de Robert Gjerdingen (2018).
} 
tratados em forma de esquemas de contraponto (schemata), se projetava como perícia para exercício da profissão;

Observar, através dos paradigmas de tratamento dos partimenti, como os usos de determinados conceitos se apresentam como uma espécie de código genético para localizarmos não só sua dinâmica da circulação dos saberes musicais dentro do espaço luso-brasileiro, mas, também, a capacidade de organizar discursos dentro das questões ideológicas vigentes.

Esse processo se dará através de excertos dos motetes de José Maurício. Nossa metodologia se pauta na articulação de diversos saberes assimilados. Primeiro, mostraremos como, a partir de um partimento básico, a Regra da Oitava, José Maurício demonstra um alinhamento com o que na época era mais atual. Para tanto, compararemos as escolhas harmônicas do compositor carioca com os conceitos expostos em tratados coevos, como os de Fedele Fenaroli (1730-1818) e Giovanni Furno (1748-1837). Já sobre os esquemas de contraponto, trataremos de demonstrar como esses suportes poderiam ser "adaptados" de sua forma escolar para criar soluções poéticas dentro de diversos contextos estéticos. Por fim, pretendemos mostrar que todos esses elementos estão sustentados no conceito de ars combinatória, ou seja, estruturas musicais convencionadas combinadas a partir de preceitos oratoriais que possibilitavam a exposição de argumentos musicais, de tal forma que poderiam ser "traduzidos" por um ouvinte "educado".

Por fim, acreditamos que este artigo pode contribuir para a melhor compreensão de todo o processo retórico à disposição dos compositores galantes, como José Maurício, através de um corpus ainda pouco analisado à luz das teorias coevas de formação de saberes teóricos do século XVIII.

\section{A Ars Combinatória, de Leibnitz para a Estética do Pólipo}

A relação da mentalidade possível do músico com os princípios da Retórica é já um tema pacificado no acervo bibliográfico sobre o exercício da música no Antigo Regime. Nas últimas décadas, o avanço dos estudos sobre essa epistemologia nos permite afirmar que a Retórica era a base primordial que dava sustentação a todo o processo sociomusical, desde as questões da educação até as relações mais profundas da recepção musical. Tanto era sua presença como 
É assim, porque é assim que tem que ser: a retórica galante nos motetes de José Maurício, observada no uso da pedagogia dos partimenti, da gramática das schemata e da oratória musical

fundamento primordial que ela define o nome que, hoje, nos referimos a essa prática musical, Estilo Galante.

O termo Galante se justifica na referência a um tipo de sociabilidade que era definida por uma etiqueta social vertida em protocolos de comportamento convencionados. Em outras palavras, uma verdadeira "retórica" social onde a expressão pessoal era constrangida por ser considerada afrontosa ao direito natural do soberano na legitimação das convenções sociais. Neste ambiente, a atenção e o uso de um emaranhado de regras e pragmáticas explicitavam o lugar de cada indivíduo dentro do sistema estamental. Aqui, os símbolos eram eloquentes e determinantes, e estavam em muitos espaços: nas mobílias sociais como as vestimentas e os utensílios usados nos corpos; nas falas, como os léxicos e sintaxes usados nas conversações ou textos como sermões; nos gestos e atos da presença, das saudações às coreografias de danças cortesãs. Tudo era marcado para que não houvesse dúvida sobre a origem social. Interpretar as significações, inclusive da música, era a essência da vida cortesã. E mesmo em cortes periféricas como a do Rio de Janeiro, onde os códigos estamentais não estavam tão arraigados na prática cotidiana, sua observância em locais restritos, como catedrais e palácios, servia para graduar as pessoas dentro do sistema cortesão. ${ }^{3}$

Porém, o saber trivial sobre Retórica Musical nos tempos atuais restringiu o uso do termo a um acervo de fórmulas passíveis de serem reconhecidos quase que mecanicamente. É comum encontrarmos abordagens que se limitam a questões de usos de figuras musicais ou aplicação direta da retárica literária para textos musicais. Porém, mesmo tendo certo grau de plausibilidade, há uma falácia quando afirmamos que as estruturas retóricas eram acervos permanentes

\footnotetext{
${ }^{3}$ É Robert Gjerdingen quem melhor define a coerência deste nome, buscando nos estudos sociológicos de Norbert Elias sua fundamentação. "Galant was a word much used in the eighteenth century. It referred broadly to a collection of traits, attitudes, and manners associated with the cultured nobility. If we imagine an ideal galant man, he would be witty, attentive to the ladies, comfortable at a princely court, religious in a modest way, wealthy from ancestral land holdings, charming, brave in battle, and trained as an amateur in music and other arts. This perfect courtier, as Baldassare Castiglione described him in 1529, would have the natural grace "to use in every thing a certain sprezzatura [nonchalance] that conceals its art and demonstrates what he does and says to be done effortlessly, and, as it were, without concern" (Gjerdingen 2007, p. 5). No mesmo trecho, o autor leva esse comportamento à experiência musical: "Galant music, then, was music commissioned by galant men and women to entertain themselves as listeners, to educate and amuse themselves as amateur performers, and to bring glory to themselves as patrons of the wittiest, most charming, most sophisticated and fashionable music that money could buy" (ibidem).
} 
MUSICA THEORICA Revista da Associação Brasileira de Teoria e Análise Musical 2020, v. 5, n. 2, p. 74-141 - Journal of the Brazilian Society for Music Theory and Analysis@ TeMA 2020 - ISSN 2525-5541

ou estáticos, usados num processo de restrição da linguagem. Isso, em certa medida se afirma por uma perspectiva teleológica da retórica, mas o meio pelo qual o fenômeno se consolidava estava sustentado numa relação dinâmica das práticas musicais com os espaços de escuta. Por outras palavras, os elementos se tornavam "retóricos" por um processo bem mais complexo do que a unção de uso em uma corte de prestígio, ou a recorrência de estruturas musicais convencionadas legitimadas por grandes mestres. Muitas forças interagiam na consolidação e legitimação de uma estrutura musical convencionada para a representação de determinadas ações ou sentimentos. Evidente que eram determinantes para o discurso musical questões como estruturas musicais retóricas extraídas de processos de legitimação social, como no caso das danças cortesãs francesas; do reconhecimento de autoridade, como soluções estruturais geradas em ensinamentos grandes mestres; ou mesmo representação de experiências culturais que animavam os estatutos de valores e crenças, como a música eclesiástica. No entanto, outras forças determinavam o condicionamento retórico musical, como, por exemplo, o vínculo do saber musical com questões dramáticas que da literatura passavam à música, como é o caso do estilo heróico e seus derivativos.

Vejamos o caso da pastoral. Esta estrutura musical simbólica acumula camadas de sentido desde a Antiguidade. Sua representação primordial é subsidiada a tudo que remeta à natureza ou ao estado de natureza. Danças rústicas, por exemplo, remetem a este estado de natureza e/ou expressão da experiência junto à natureza. Porém, no encadeamento poético dos séculos chega aos anos setecentos simbolizando tudo o que o rústico permite, da alegria dionisíaca das danças campestres à pureza virginal dos cultos marianos. Isso se estende, por exemplo, para um schema muito comum, tão comum que ainda hoje está em vigência, inclusive na música popular: a romanesca. Antes de ser um esquema de contraponto, a romanesca era uma estrutura musical geralmente usada em canções rústicas, como os vilancicos, e que, do uso exaustivo associado a uma determinada situação, tornou-se um padrão retórico para conotações que se pretendem específicas para o universo galante. ${ }^{4}$

\footnotetext{
${ }^{4}$ Em termos da tradição da música aristocrática, a romanesca é sobejamente discutida no livro seminal de Robert Gjerdingen, Music in the Galant Style (2007). O autor apresenta que a realização desse schema está vinculada a dois movimentos principais de baixo: (1) o baixo descendente por grau conjunto (1), (7), (6), (5), (4) e (3), que deve ser realizado com a alternância de acordes ${ }_{3}^{5} \mathrm{e}$
} 
É assim, porque é assim que tem que ser: a retórica galante nos motetes de José Maurício, observada no uso da pedagogia dos partimenti, da gramática das schemata e da oratória musical

Assim é sempre útil reconhecer, primeiro, que a Retórica, num sentido geral, não respondia unicamente a um procedimento criativo que permitia o uso de modelos para diversas ocasiões, projetando as ideologias de zonas de influência e poder para dentro de um quadro referencial legitimado pela potência dos lugares de falas. Ela se projetava como uma epistemologia que atravessava a totalidade da sociedade. Era, antes de mais nada, uma operação mental ensinada desde a mais tenra idade, não só como base do pensamento especulativo medieval estabelecido na estrutura educacional do Trivium e do Quadrivium, mas pelos atos de apreensão do mundo, como sermões, contos, pragmáticas cortesãs, liturgias, enfim, tudo que tivesse vínculo com a

${ }_{3}^{6}$ (Gjerdingen 2007, p. 29). Este padrão foi difundido no final do século XVIII e, na prática galante, foi sintetizada no movimento de baixo (1), (7), (6) e (3). (2) O baixo que ocorre por meio de repetições de um padrão, desce quarta e sobe segunda (1), (5), (6) e (3)). Esta é uma forma mais antiga do schema e deve ser realizado com acordes na posição fundamental, ou seja, $\frac{5}{3}$. Porém, o que não discute Gjerdingen é a capacidade expressiva e sintática desse esquema harmônico, e sua projeção insuspeitáveis para os mestres dos parimenti do século XVIII. Assim, se a romanesca nos chegou através de obras muito populares do repertório "erudito", como é o caso do Canon em D, de Johann Pachelbel, podemos senti-la, também, em outros universos. Provavelmente associado a algo subjacente a ela, ou seja, ao padrão contrapontístico em si, a sua capacidade de síntese tonal para uma abertura de unidades musicais, ou mesmo sua plasticidade estrutural, se faz sentir ainda hoje. Por outras palavras, parece ser que um sentido da coerência formal projetou esse esquema para universos fora do âmbito galante. Para não se estender, a romanesca, que em termos de harmonia se traduz na progressão I-V-vi-viio/IV-IV-I, pode ser sentida na música popular contemporânea, principalmente por um modelo simplificado conhecido como sequência de rádio (I-V-vi-IV). Essa progressão, digamos parental, no repertório da canção comercial é tão marcante que foi satirizada por um pot-pourri do grupo The Axis of Awesome, 4 Four Chord Song. Não só isso, podemos encontrar tal progressão em muitos tipos de canção, do Rock ao Sertanejo Universitário. Um ouvido treinado haverá de sentir uma romanesca em canções dos Beatles (de forma "escolar" em In My Life e sem a dominante individual do IV, em Let It Be), de Bob Marley (No woman, no Cry) ou do U2 (With or With Out You). O mesmo podemos dizer de canções de artistas nacionais, como do Charlie Brown Jr. (Papo Reto) e, no outro extremo, em uma canção de Fernando \& Sorocaba (Bala de Prata). Aparece, também, como citação do famoso Canon de Pachelbel na introdução da canção Teatro dos Vampiros (da banda Legião Urbana). Para além dessa progressão, o baixo descendente por graus conjuntos da romanesca é uma sonoridade recorrente e podemos citar seu uso em inúmeros exemplos. Alguns são marcantes, como Se fiquei esperando o meu amor passar, da Legião Urbana, e Wake me up when september ends, da banda de Punk Rock Green Day. Apesar dessas recorrências, não queremos dizer que esses usos formam uma ponte com o passado, através de um processo de ressignificação harmônica ou alguma estética neoclássica. Apenas que essa progressão tem um poder de síntese/significação do que chamamos de coerência tonal, assim como sua função sintática para inícios de trechos musicais é potente. Assim, acreditamos que a sua vigência atual está no que ela potencializa como gramática para ordenação da forma e recurso melódico, mesmo quando não se reconheça a sua antiguidade. 
MUSICA THEORICA Revista da Associação Brasileira de Teoria e Análise Musical 2020, v. 5, n. 2, p. 74-141 - Journal of the Brazilian Society for Music Theory

legitimação epistemológica de uma ordem social que se baseava na aceitação de uma plenum formarum, ou seja, uma organização da Natureza, e da vida, a partir de uma ordem suprema da razão, estática e estável, e que inclusive, sustentava a ideia de um direito natural de poder pelo soberano. Tinha como princípio a ideia de representar, para fins de discurso, um mundo através dos universais (no caso da música, isso a remete ao conceito de afetos e das tópicas). Tais universais estariam dispostos numa lógica forjada numa uma última instância da realidade, na qual a Retórica dá acesso como uma ars atium (uma razão de onde derivam todas as outras). Neste processo cognitivo, a verossimilhança era tida como uma verdade que concentrava todas as particularidades e, assim, permitia a revelação unívoca de uma realidade geral de um sentimento, ação, dignidade social etc.

É nesse sentido que a Retórica, como arte da argumentação, logo, como ponte de acesso ao plenum formarum, se alinhava às ferramentas de afirmação do modelo social cortesão, onde a capacidade de identificação e exposição simbólica revelava a essência da própria sociedade como estrutura de subordinações. Logo, um símbolo não era apenas representativo de uma ideia compartilhada. Ele era um código que desvelava as marcas sociais a partir do reconhecimento de uma camada sedimentar de sentidos tradicionais. O corpo do soberano era, sobretudo, a representação de um corpo de tradições, entendido como divino.

Assim devemos compreender que, como código, as estruturas retóricas formavam um complexo corpus que legitimava um modelo de capital simbólico usado pelas diversas camadas de poder (civil e eclesiástico) para manter a estabilidade numa sociedade que se sustentava na distinção entre as pessoas. Porém, devemos ressaltar que, enquanto modelo retórico-musical para a escuta no Antigo Regime setecentista, a questão ainda necessita de outras observações que se fundam na experiência de uma comunicação de ordem não verbal.

Primeiro, é necesseario compreender a relação primordial dessa escuta: a experiência culta. Por exemplo, os elementos referencias, ou seja, as estruturas musicais convencionadas, formavam um espaço compartilhado de experiências, sonoras e sócias mediadas pelas formas discursivas do poder estabelecido. Só a partir deste pressuposto podemos imaginar o processo comunicativo potencializado pela retórica-musical (que era um fato). Isso porque, como unidades convencionadas, elas eram reagentes em seus ambientes naturais (uma dança num salão de baile) ou deslocados de sua função social (uma dança numa sonata). Assim, escutar um minueto no salão de dança no momento de um ato 
É assim, porque é assim que tem que ser: a retórica galante nos motetes de José Maurício, observada no uso da pedagogia dos partimenti, da gramática das schemata e da oratória musical

dançante não é a mesma coisa do que escutar um minueto numa sinfonia, num ambiente de conversação.

Isso nos leva ao âmago do problema da retórica musical: a questão das capacidades de escuta e interpretação. Retornando ao exemplo do minueto é legítimo supor que uma pessoa educada deveria reconhecer as estruturas básicas deste tipo de dança. Somente assim, ou seja, a partir do reconhecimento pela experiência imediata, é que o processo comunicativo se efetivaria. Inclusive se efetivaria num saber simbólico, ou seja, quando o minueto era "deslocado" do ambiente original. Aqui, ele apareceria em sua iconicidade, ou seja, o ouvinte em tese reconheceria a gestualidade musical por semelhança e, também em tese, seria levado a um processo de relações de significado expandindo, ou seja, um processo de correlação de sentidos. E seria nesse nesse primeiro impulso, o reconhecimento icônico, que se desdobraria o efeito indexal do signo exposto, potencializado pela relação de experiências vividas que criariam expectativas de associações no jogo da audição.

A isso soma-se algo sutil, o fato dos elementos convencionados (as estruturas retóricas como as tópicas) potencialmente funcionarem como estruturas discursivas para suscitar respostas afetivas nos ouvintes, e não como elementos de discrição de lugares, ações ou sentimentos. Esse processo, ou seja, de uma doutrina da resposta subjetiva por afecção, se intensificou no século XVIII, principalmente no que chamamos de música galante como explica Gregory Decker (2020, p.135)

A combinação da (a) necessidade de expressar com precisão um afeto em uma composição musical e (b) a prática histórica de conceituar a construção musical em termos de retórica levou ao que mais tarde foi denominado a "doutrina dos afetos" - na música, como em retórica, o compositor escolheria uma ideia musical que despertasse a paixão apropriada no ouvinte. Os teóricos do século XVIII, em vez de encontrar correlações entre estilos musicais e significado cultural, encontraram correlações entre estilos musicais e expressão afetiva e usaram a retórica como uma ponte entre os dois. ${ }^{5}$

5 "The combination of (a) the need to accurately express an affect in a musical composition and (b) the historical practice of conceptualizing musical con struction in terms of rhetoric led to what was later termed the doctrine of affections" - in music, as in rhetoric, the composer would choose a musical idea that would arouse the appropriate passion in the listener. Eighteenth - century theorists, instead of finding correlations between musical styles and cultural meaning, found 
E todo esse processo tinha um ponto de partida para uma história dos efeitos nos compositores galantes. Trata-se do conceito de Ars Combinatória que tanto impacto teve nas reformas acadêmicas impulsionadas no movimento iluminista, de meados do século XVIII. Foi desenvolvido nos estudos doutorais de Gottfried Leibniz (1646-1716) e, seu marco editorial foi em 1666, como Dissertatio de arte combinatória. Essa doutrina ganhou impulso no momento em que epistemólogos discutiam os universais numa perspectiva do empirismo inglês; empirismo que, inclusive, seria trabalhado na elaboração da doutrina dos signos de John Locke (1632-1704).

Em parcas linhas, Leibniz propôs uma teoria cognitiva que pressupõe uma ampla combinação de elementos sensíveis-por isso empírico-para que a representação de algo se concretize. Essa operação se dava não em categorias, mas sobre as propriedades particulares de cada objeto, e como esses objetos se relacionavam com os problemas postos por uma argumentação. O processo se daria então em perspectivas, empíricas, mas, também, analíticas, porque dependia da consciência detalhada de cada possibilidade dada por uma coisa (objeto ou afeto). É esta a perspectiva analítica de cada coisa que "exigia" um jogo de permutações das possibilidades cognitivas para uma representação que seja fidedigna, ou desveladora de uma verdade, no trato de um assunto.

Para a música, a ars combinatória afetava desde a melodia até o jogo de especificação simbólica a partir de alterações específicas nos elementos convencionados, como as tópicas (o proncípio da tropificação). Na melodia, a combinatória se dava como um processo de controle de probabilidades, ou seja, as várias possibilidades de combinação rítmica num mesmo conjunto de alturas. Aliás, esse princípio foi expandido através de melodias formadas por motivos que podem ser desenvolvidos individualmente, combinados por uma lógica motívica. Haydn, por exemplo, apresenta esse sentido da lógica combinatória a partir de seu Op.33. Sobre as tópicas, a combinatória se dá nos jogos dos estilos, ou seja, quando léxicos de uma determinada estrutura simbólica são usados em

correlations between musical styles and affective expression and used rhetoric as a bridge between the two" (tradução nossa). 
É assim, porque é assim que tem que ser: a retórica galante nos motetes de José Maurício, observada no uso da pedagogia dos partimenti, da gramática das schemata e da oratória musical

outra. ${ }^{6}$ Por exemplo, tempestas e pastorais eram frequentemente combinadas em projetos expressivos dos compositores galantes, a ponto de induzir a considerações de modelos expressivos formais, como a abenegação.

Estas afirmações, aliás, são sustentadas por Stephen Rumph. Em Mozart an Enlightenment Semiotics, deixa claro que essa poética era uma pertença da estética galante. Através de cartas de Mozart, ou mesmo trechos do famoso tratado de seu pai, Leopold Mozart, o autor encontra princípios que ecoavam pressupostos do empirismo analítico que circulavam como saberes "cultos" absolutamente assimilados em meados do século XVIII (Rumph 2012, p. 4):

Se essa abordagem parece perigosamente abstrata, consideremos a alternativa. Suponha que descobríssemos uma "arma fumegante", para que pudéssemos provar que Mozart leu um determinado tratado. Na verdade, esse exemplo existe. Em uma carta de 4 de abril de 1787, Mozart parece ter parafraseado uma passagem do Phddon de Moses Mendelssohn, um livro que ele possuía. Se Mozart leu o curto diálogo em sua totalidade, como não parece improvável, ele se deparou com este relato da cognição humana: 'Com cada sensação, uma multidão de cognições flui para [o indivíduo], que são inexprimíveis para a língua humana; e se ele justapõe as sensações umas às outras, se ele compara, julga, decide, escolhe, rejeita - ele multiplica essa multidão ao infinito. Ao mesmo tempo, uma atividade incessante desdobra as capacidades do espírito inatas nele' (ibidem, p. 4-5).7

Por sua vez, Wye Allanbrook (2014), em seus estudos sobre a música galante, estabelece uma feliz relação entre a estética dos motivos "concentrados" com a lógica combinatória da época. Através de um diálogo filosófico de Diderot - Le Neveu de Rameau ou La Satire seconde (1805) - Allanbrook observa o estilo galante por uma analogia do iluminista francês: a música se comportava como

\footnotetext{
${ }^{6}$ Apenas como exemplo, veja o trabalho de combinatória que Haydn propõe no primeiro movimento da sinfonia 80, a partir de dois campos expressivos fortes: a tempesta e um tipo de dança, o minueto.

7 "If this approach seems perilously abstract, let us consider the alternative. Suppose that we discovered a 'smoking gun,' that we could prove that Mozart read a particular treatise. In fact, such an example exists. In a letter of 4 April 1787, Mozart seems to have paraphrased a passage from Moses Mendelssohn's Phddon, a book he owned. If Mozart read the short dialogue in its entirety, as seems not unlikely, he came across this account of human cognition: 'With every sensation a multitude of cognitions streams into [the individual], which are inexpressible to the human tongue; and if he juxtaposes the sensations to each other, if he compares, judges, decides, chooses, rejects-he multiplies this multitude into infinity. At the same time, an unceasing activeness unfolds the capabilities of the spirit innate in him'" (tradução nossa) (Rumph 2012, p. $4-5)$.
} 
MUSICA THEORICA Revista da Associação Brasileira de Teoria e Análise Musical 2020, v. 5, n. 2, p. 74-141 - Journal of the Brazilian Society for Music Theory and Analysis@ TeMA 2020 - ISSN 2525-5541

um pólipo; e essa era uma tradição vinda da ópera bufa. A pertinência dessa metafóra era justamente calçada na ideia de relações construídas através de fragmentos derivados de um mesmo corpo. E assim reproduz a essência dessa estética, pelas palavras de Diderot:

É o grito animal da paixão que deve ditar a linha melódica, e suas expressões devem ser urgentemente reprimidas, uma após a outra; a frase deve ser curta, o significado cortado, suspenso; o músico deve poder fazer uso do todo e de cada uma das partes - omitir uma palavra ou repeti-la, acrescentar uma palavra que falta, virar a frase para trás e para fora como um pólipo, sem destruí-la (apud Diderot [1805], Allanbrook 2014, p. 1)

Assim, quando falamos em Retórica, primeiro devemos assumir que ela era mais do que um acervo. Era uma epistemologia que se espraiava como filosofia, ciência e, claro, pedagogia. E, dessa forma, se tornou um processo de pensamento que "atingia" diretamente todo o mecanismo criativo, em níveis profundos.

Como isso se deu na música?

Primeiro, na organização de estruturas expressivas assumidas como um capital simbólico de metáforas sonoras das coisas cotidianas, de várias espécies e amplamente compartilhado. Segundo, como bem observou Mark Evan Bonds (1991), a Retórica Musical afetava não só a questão expressiva, mas, também, questões formais (entre outros efeitos, é esse aspecto que torna a arte musical do Antigo Regime muito dependente de uma hermenêutica de diversos fundos). Evan Bonds, aliás, descortinou um princípio que questionava a prevalência de uma Formenlehre ao declarar que a música era, assim como a literatura, uma operação da Oratória. Aliás, os escritos de Evan Bonds lançaram luz a várias "irregularidades" que a racionalização da Formenlehre encobriu como, por exemplo, a questão dos motivos da "plasticidade" da forma sonata.

Em síntese, o simples fato de considerar a música dentro de um princípio da Oratória, ou seja, uma arte da argumentação construída a partir de uma proposta expressiva (motivo ou tema) articulada em relação à ocasião, espaço e dignidades de fala, permitiu vislumbrarmos a forma como um meio, um suporte, e não um fim em si mesma. Porém, mais que isso, abriu um campo de especulação que nos exige vínculos com processos histórico-culturais mais amplos do que simplesmente a taxonomização de figuras de linguagem e campos expressivos, esquemas formais e lógica harmônica estabelecida numa virtual associação funcional dos acordes. 
É assim, porque é assim que tem que ser: a retórica galante nos motetes de José Maurício, observada no uso da pedagogia dos partimenti, da gramática das schemata e da oratória musical

Portanto, o primeiro passo para quem busca realizar uma análise de música deste período é considerar que a Retórica articulava saberes de diversas ordens, da literatura à cosmologia (o que considera não só a teologia cristã e suas liturgias, mas outras formas místicas, como a cabalística); dos saberes protocolares cortesãos, como a experiência com danças, às questões filosóficas da época (a relação de Beethoven com os postulados de Schiller é um bom exemplo). Segundo, é preciso entender que a Retórica era o espaço das referências, onde o domínio de simbologias, fórmulas, pragmáticas, protocolos cerimoniais etc se consubstanciava através de metáforas musicais. Metáforas que eram articuladas pelos exercícios da Oratória, ou seja, a ars que organizava uma lógica musical para dar a um discurso não verbal possibilidades de inteligibilidade ao homem educado (este é o sentido de erudição pelo qual denominamos essa música).

Nesse espaço a perícia atuava na arte de formular o argumento no sentido de transformar parâmetros musicais padronizados em discursos específicos. A gramática ficava restrita ao campo das regras, ou seja, aos limites do que é permitido em termos de teoria musical (escalas, contrapontos, métricas etc). $\mathrm{Na}$ prática, a música se dava por um processo de composição (no sentido de organização), mais do que de criação (no sentiodo de inovação), já que o compositor "escolhia" recursos pré-estabelecidos no ato do projeto expressivo; este era o processo, abstrato, da inventio (estabelecida no ato de pensar a música, e não como passos concretos a serem seguidos). Na inventio, cada projeto articulava a localização de parâmetros específicos para a inteligibilidade do processo significativo em relação a sua finalidade. Por exemplo, uma tonalidade de Sol menor de partida potencializava questões de caráter grave, geralmente disfórico. Associada a uma métrica em dáctilo, em movimento moderado, era já algo marcado pela morte. Danças lentas, por exemplo, era para momentos solenes. Em árias, danças lentas sustentavam falas de autoridades com caráter grave.

Por outras palavras, a música se organizava como projeto a partir de modelos expressivos apreendidos na capacidade do reconhecimento das referências. Isso quer dizer que as "escolhas" não eram um jogo aleatório, de um ego criativo individual, mas um processo restritivo, inclusive passível de revelar modelos de combinação através da correlação com as perspectivas de grandes estruturas dramáticas, como a tragédia, a comédia, a elegia; ou o conjunto das danças em relação às dignidades de seus usos. 
Outrossim, musicalmente podemos observar pela Oratória um espaço que revela quadros muito precisos de alinhamentos histórico-ideológicos, através do reconhecimento não só dos processos formais, mas principalmente do arcabouço simbólico usado. Desta forma, uma visão apurada conseguiria observar um discurso musical desde um perfil tradicionalista, com conceitos presos a doutrinas escolásticas, por exemplo, até propostas de rupturas, como a “Nova Retórica" dos Árcades (último quartel do século XVIII).

\section{Partimenti e Schemata: antigas ferramentas e as "não tão" novas teorias para a análise da música galante}

Acima buscamos apresentar uma breve consideração sobre a epistemologia dos processos criativos galantes. Partimos afirmando que ela se dava na plataforma doutrinária da ars combinatória. Agora, devemos dar um passo para compreender como se dava a articulação prática de todo esse processo.

De partida, devemos compreendê-lo fora da nossa ideia de gênio criativo. As ferramentas necessárias para transformar a música num objeto comunicativo da ordem ideológica hegemônica, por fazer parte da formação educacional das esferas altas da sociedade cortesã, eram de caráter controlado. Isso significa que era preciso ter ciência de muitos referenciais para que, numa sociabilidade plena de distinção estamental, os elementos expressivos fossem compreendidos e expostos numa perspectiva de decoro cerimonial. Era sobretudo uma base pragmática de ação.

Como auxiliares na formação desse ambiente, o processo pedagógico para ensinar músicos a usar estruturas simbólicas para o processo sociocomunicativo da música era rigoroso. Ampliando o que acabamos de afirmar, as estruturas musicais deveriam ser reconhecidas para que o processo de compartilhamento fosse ativado. Esse processo, a partir do final do século XVII, articulou algumas didáticas, como o solfeggio (o adestramento para ornamentar melodias) e o partimento (metodologia para o adestramento para resolver o contraponto, apreender os campos expressivos em relação às suas harmonias, e, ao mesmo tempo, articular a forma musical).

Justamente foi reconhecendo essa pedagogia que, desde a década de 1980, uma concepção analítica sobre a música do século XVIII vem se consolidando. 
É assim, porque é assim que tem que ser: a retórica galante nos motetes de José Maurício, observada no uso da pedagogia dos partimenti, da gramática das schemata e da oratória musical

Como já é de amplo domínio, o marco desse processo são os estudos de Leonard Ratner sobre as tópicas musicais. As primeiras publicações datam do final da década de 1950. Esta foi uma época de grandes questionamentos sobre as fronteiras da Formenlehre como traçadas no final do século XIX. Muitos autores começaram a questionar questões de estilo e gramática dessa música. Leonard Meyer foi um dos principais pensadores sobre essas questões. Partindo do trabalho sobre métricas e ritmos, e de sua natureza retórica, foi, aos poucos, formulando sua ideia de estilo. Outras contribuições igualmente acumularam experiências importantes sobre as estruturas formais, como os escritos de Carl Dahlhaus sobre retórica de meados da década de 70. No entanto, a renovação só se articulou com consistência ampla nos anos 90, ou seja, mais de dez anos após o lançamento de Classic Music, de Leonard Ratner (1980).

Em parcas palavras, esses estudos buscaram os processos epistemológicos de formação de sentido teórico no jovem músico setecentista, e sua "presença" como suporte do processo criativo. A primeira questão que concentrou esforços foi o que significaria, na prática da composição, a retórica musical. Evidentemente, uma primeira geração descortinou toda uma taxonomia sobre figuras musicais. Posteriormente, a ideia de retórica foi compreendida dentro de um problema mais amplo, como a Oratória, como propôs Mark Evan Bonds. Em pouco tempo, dentro da década de 1990, questões sólidas, como a da forma musical, passaram a ser vistas como teorias que se projetaram escolarmente sobre a música galante, a partir do século XIX. E a forma é um assunto importante, pois a cada análise percebia-se que ela era um suporte para projetos expressivos vinculados à articulação da música a contextos diversos: não só do lugar, mas da qualidade e da dignidade do lugar, e sua relação com a exposição dos argumentos musicais.

Vindo de outra vertente da teoria musical, a Semiótica da Música, autores como Raymond Monelle e Robert Hatten avançaram sobre a compreensão desse processo criativo por estruturas retóricas usando princípios peirceanos, mas não só, evidentemente. Para esses autores, todo esse processo de formação dos elementos pré-composicionais, e a forma como eles eram reconhecidos pelas audiências, seria mais bem estruturado ao compreendermos os jogos dos signos dentro da lógica musical. Em parcas palavras, amplificaram o conceito de tópicas musicais até chegar a modelos como os do gênero expressivo, de Robert Hatten (1994). 
MUSICA THEORICA Revista da Associação Brasileira de Teoria e Análise Musical 2020, v. 5, n. 2, p. 74-141 - Journal of the Brazilian Society for Music Theory and Analysis@ TeMA 2020 - ISSN 2525-5541

No entanto, todos estes estudos ganharam bastante corpo quando os processos pedagógicos do século XVIII foram sistematizados. A partir da compreensão de como se estabelecia a formação do músico, principalmente nos conservatórios napolitanos, foi possível afirmar com mais certeza como se assimilavam as ferramentas retórico-musicais. Neste campo, foram decisivos os estudos sobre os esquemas de contraponto de Robert Gjerdingen (2007) e a consolidação dos estudos sobre partimenti de Giorgio Sanguinetti (2012). ${ }^{8}$ A partir desse corpus, a articulação analítica potencializou-se e, de forma crescente, incontáveis estudos surgiram para ampliar o alcance desses processos.

Dentro dos estudos sobre os processos pedagógicos de Nápoles muitos aspectos se desdobraram. Um importante foi o que mostrou como esses procedimentos alcançaram as bordas do mundo sob influência europeia, como a

\footnotetext{
8 O livro Music in the Galant Style (2007), de Robert Gjerdingen, apresenta uma importante conceitualização da prática galante, além de pequenos textos com biografias e descrições de determinadas etapas que nos proporcionam entendimentos sobre a manipulação dos materiais musicais pelos grandes mestres napolitanos. Desta forma, o consideramos como uma espécie de marco teórico do assunto, após um aumento no número de artigos publicados que envolvem a prática pedagógica napolitana nos anos 1990. Neste corpus, destaque para os textos de Rosa Cafiero (La didattica del partimento a Napoli fra Settecento e Ottocento: Note sulla fortuna delle Regole di Carlo Cotumacci, 1993), sobre o ensino de partimento nos conservatórios Napolitanos, e de Giorgio Sanguinetti (Un secolo di teoria della musica in Italia: Bibliografica critica 1850-1950, 1997), sobre esta tradição na teoria musical italiana. Aliás, outra obra de Giorgio Sanguinetti, The Art of Partimento (2012), pode ser considerada a obra mais importante sobre o assunto, pois contém em detalhes a descrição histórica e dos procedimentos para a realização dos partimenti com base na análise de fontes primárias encontradas em bibliotecas europeias. Além destes seminais trabalhos, são importantes os trabalhos de Peter Van Tour (Counterpoint and Partimento: Methods of Teaching Composition in Late Eighteenth-Century Naples, 2015), que trata do contraponto na escola Italiana; o livro de Job Ijzerman (Harmony, Counterpoint, Partimento: a new method inspired by old masters, 2018), que descreve as principais ideias do método, com foco na aplicação dos partimenti nas práticas mais contemporâneas, e o recém lançado livro de Robert Gjerdingen, Child Composers in the Old Conservatories (2020). Além disso, temos importantes artigos, dentre eles os reunidos em Partimento and Continuo Playing in Theory and in Practice (2010), com textos de Thomas Christensen, Robert Gjerdingen, Giorgio Sanguinetti e Rudolf Lutz. Outra fonte de informação importante para é o site desenvolvido por Robert Gjerdingen (2020), Research into the history, theory and cognition of music, que contém edições de diversos cadernos e também estudos sobre o assunto. Por fim, o site Partimenti se apresenta como aquele que contém o maior acervo com materiais sobre o assunto disponível na rede, com cadernos dos principais autores, além de outros assuntos relacionados à pedagogia napolitana, como o solfeggi, o contraponto, a fuga, a harmonia e outros temas. No Brasil dois textos dão início ao debate: a tese de doutoramento de Mário Marques Trilha, Teoria e Prática do Baixo Contínuo em Portugal (1735-1820) (2011) e o texto de Ozório Bimbato e Diósnio Machado Neto, Nápoles, Lisboa e São Paulo: a tradição dos partimenti no século XVIII (2013).
} 
É assim, porque é assim que tem que ser: a retórica galante nos motetes de José Maurício, observada no uso da pedagogia dos partimenti, da gramática das schemata e da oratória musical

Rússia e o Novo Mundo. Estudos como os de Cristina Fernandes e Mário Trilha, por exemplo, revelam como qualquer músico profissional e estabelecido, como José Maurício Nunes Garcia, tinha sua formação em cadernos que eram feitos ou adaptados por mestres sob a influência italiana de ensino. Professores como David Perez (1711-1778) e José Joaquim dos Santos (1747-1801) usaram partimenti próprios e/ou copiados dos napolitanos na formação de pelo menos três gerações de músicos atuantes na Metrópole ou em suas colônias, como o Brasil (cf. Fernandes 2013).

Fechando essa explanação, estudos recentes mostram a existência de um circuito de saberes articulados pela inserção de instituições de ensino, como o Real Seminário da Patriarcal de Lisboa, dentro dos campos disseminadores da hegemonia artística italiana. Circuito que garantia a comunicabilidade da música dentro da zona de influência e poder do Antigo Regime. Modelando e legitimando as metáforas musicais por uso, mas, também, pela capacidade de projeção de costumes, uma cultura musical de fortes marcas ideológicas se projetava como um cânone a ser seguido.

O alcance dessa estrutura de saberes foi de tal dimensão que possibilitava a um nobre russo ou um membro da elite da terra no Rio de Janeiro manejar alguma referência em comum quando escutassem um lamento num motete de Semana Santa; no mínimo, os dois teriam alguma crítica sobre o "justo" decoro, quando relacionassem espaço e escuta. Aliás, o decoro era a palavra-chave para o sossego público. Mestres de capela faziam desse conceito sua fronteira de experimentação. Isso porque, num regime que necessitava o reconhecimento simbólico de crenças e valores para manter sua estabilidade, a simbologia deveria ser assimilada para manter a ordem da dominação, mesmo sem a presença física dos órgãos de poder e repressão. A arte institucional (da Igreja e dos palácios) cumpria essa função sobejamente, quando atenta ao decoro. E o desenvolvimento de pedagogias como a do partimento ajudava nessa missão.

\section{Breve introdução aos fundamentos da pedagogia napolitana}

Neste ponto, passemos às questões práticas desse ensino. O primeiro que se exige explicar é a diferença entre partimenti e schemata. Pode-se considerar os dois fenômenos coligados, porém, eles têm naturezas diferentes. Se partimento é a ferramenta para aprender a resolver estruturas musicais (harmonia e forma), 
MUSICA THEORICA Revista da Associação Brasileira de Teoria e Análise Musical 2020, v. 5, n. 2, p. 74-141 - Journal of the Brazilian Society for Music Theory and Analysis@ TeMA 2020 - ISSN 2525-5541

as schemata são, como diz o nome, esquemas amplamente recorrentes na prática musical que se projetam como fontes de organização harmônica, logo, suporte das estruturas formais e expressivas. Em outras palavras, os partimenti servem à pedagogia do contraponto e as schemata servem à práxis da composição profissional. Em síntese, os dois se retroalimentam.

Porém, podemos avançar nessa distinção. Vinculado à sintaxe musical do período galante, as schemata eram parte de um modelo de escuta, onde a audiência "compartilhava" o reconhecimento desses esquemas, ou seja, indivíduos deveriam ter ciência do que escutavam para, em tese, o significante harmônico ter um mesmo significado, ou próximo. Era por este jogo, ou idealização, que o processo sociomusical galante se fiava. Em síntese, os músicos e suas audiências deveriam compartilhar escutas, não só como fenômeno auditivo, mas como processos de correlações de valores, principalmente simbólicos.

Foi dentro deste espaço que floresceu um projeto pedagógico, o ensino dos partimenti. Essa pedagogia que provavelmente nasceu na virada do século XVIII, proporcionava ao estudante de música, desde o início dos seus estudos, um amplo entendimento das ferramentas composicionais que criavam as relações de inteligibilidade: desde as relações das estruturas harmônicas com gêneros até as questões de significação que esta relação poderia suscitar num sentido mais amplo dos elementos associados dentro da composição. Em síntese, o partimento articulava vários elementos da "gramática musical", desde a harmonia/contraponto, métrica, melodia, forma, mas, também, algo da retórica, ao trabalhar junto à forma e a harmonia, elementos de natureza expressiva.

Em termos práticos, podemos definir o partimento numa perspectiva simples. Aos olhos contemporâneos, seria uma linha de baixo que deveria ser realizada. No entanto, era mais que isso, porque estes baixos traziam embutidas soluções contrapontísticas filtradas pelos usos e costumes da prática musical. Em outras palavras, o aluno deveria reconhecer o baixo, tipificando-o. Ao fazer isso, já saberia qual contraponto caberia a ele. Vale salientar, também, que os partimenti não eram escritos apenas em clave de Fá. Em alguns procedimentos mais avançados, mudanças de claves ocorriam frequentemente justamente para criar situações de resoluções formais ou expressivas.

Outrossim, é importante sublinhar que o método se desenvolveu de forma oral. Os mais antigos documentos demonstram que os primeiros procedimentos 
É assim, porque é assim que tem que ser: a retórica galante nos motetes de José Maurício, observada no uso da pedagogia dos partimenti, da gramática das schemata e da oratória musical

registrados eram pequenas anotações, que funcionavam mais como um lembrete para o aluno do que lições na forma como conhecemos hoje. Percebemos, também, que os assuntos transmitidos variavam de ordem dentro dos cadernos. Entre os pontos recorrentes estavam as questões definidas pelos conceitos de consonâncias e dissonâncias; a posição das mãos; a diversidade de padrões, tidos como regra (entre elas a harmonização "das oitavas" e as cadências); e, principalmente, a articulação das harmonias com as formas musicais; problema esse que culminava na prática da composição de fugas.

Muitos mestres se destacaram nesse labor. Entre os que melhor representaram essa pedagogia, transformando-se em escolas conceituais, estavam dois mestres napolitanos: Leonardo Leo (1694-1744) e Francesco Durante (1684-1755). A polarização entre os dois estava além de uma rivalidade natural dentro de um território específico, eram rivalidades de paradigmas. E esse confronto marcava a forma como as escolas se sucediam, mantendo determinadas doutrinas, mas acrescentando novos entendimentos de questões das propriedades contrapontísticas.

Esse é o caso de dois importantes mestres que, de certo modo, projetam paradigmas que fundam os usos de compositores como José Maurício Nunes Garcia: Fedele Fenaroli e Giovanni Furno. Apenas como uma pequena introdução, podemos dizer que o tratado de Fenaroli, publicado em 1775, se tornou um dos textos mais reproduzidos sobre partimenti. Entre muitos logros, esse tratado incorpora as grandes discussões em voga de sua época, como as questões das dissonâncias na condução das vozes. ${ }^{9}$ Por sua vez, o caderno Metodo facile, breve e chiaro delle prime ed essenziali regole per Accompagnare i partimenti senza numeri (1817), de Giovanni Furno, complementa a apresentação de regras que não estão no caderno de Fenaroli, como a terminzione di tono. Além do mais, se Fenaroli encontrou projeção pelo impacto de seu tratado, Furno foi considerado um dos maiores professores de Nápoles, tendo como alunos Vincenzo Bellini (1801-1835) e Saverio Mercadante (1795-1870), entre outros. No entanto, pese as diferenças, ambos mestres se reconhecem na escola durantisti. E, nas

\footnotetext{
${ }^{9}$ Este tratado foi escrito em duas partes, que se auto completam. A primeira equivale ao caderno intitulado Regole musicali per i principianti del cembalo (1775). Este texto consolidou de tal modo as regras gerais do partimento que foi amplamente copiado, reeditado, impresso e difundido, até o início do século XX. A segunda parte é uma coleção de seis livros contendo diversos partimenti que cobrem toda a prática do ensino (Cafiero 2007; Sanguinetti 2012).
} 
MUSICA THEORICA Revista da Associação Brasileira de Teoria e Análise Musical 2020, v. 5, n. 2, p. 74-141 - Journal of the Brazilian Society for Music Theory and Analysis@ TeMA 2020 - ISSN 2525-5541

transformações do tempo, o caderno de Furno não é mais uma coleção de partimenti como outros modelos que encontramos, e sim uma espécie de manual de regras entremeadas com pequenos partimenti que funcionariam como uma espécie de verificação de aprendizagem.

\section{Princípios básicos}

O primeiro aspecto é entender o que desenvolvia a pedagogia dos partimenti. Seguindo o exposto por Sanguinetti (2007), os pontos centrais de uma primeira parte de ensino tratavam: (1) da coerência tonal, ou seja, a importância e tratamento da escala maior e da escala menor no método; (2) da definição do que é consonância e dissonância; e (3) das cadências, que são compostas por uma tônica de abertura, uma dominante e uma tônica de fechamento..$^{10}$ A segunda parte era para aprender a relacionar as cadências na articulação das formas (o que podia significar tanto o fechamento de uma determinada fórmula, quanto a primeira estrutura tonal significativa). Por fim, estavam as progressões harmônicas, e, de modo eloquente, o tratamento da Regra da Oitava, ou seja, a harmonização das escalas maior e menor, ascendente e descendente.

Entre muitas lições dos partimenti, uma se destaca para o aprendizado das progressões harmônicas, a Regra da Oitava. Esta consiste basicamente em saber qual tipo de intervalo se deve colocar sobre cada grau da escala, tanto maior, quanto menor. A ideia principal é que cada grau da escala é associado a um tipo de harmonia individual, a ponto de dar um caráter ao grau (Fig. 1).

Outrossim, a Regra de Oitava era aprendida como guia para a realização do contínuo, além de "incutir uma sensação de progressão tonal pela qual se poderia improvisar (ou 'modular') dentro de um determinado tom" (Christensen 2010, p. 24). Trilha Neto (2011), contribui afirmando que as duas funções principais e complementares da Regra da Oitava consistiam em: "fornecer aos acompanhadores e compositores iniciantes um padrão seguro de acompanhamento e harmonização das escalas diatônicas e, a segunda, servir de

\footnotetext{
10 Apenas para referência, as cadências são classificadas com base na unidade métrica ocupada pela dominante. São nomeadas como cadenze semplici, cadenze composte e cadenze doppie (cadência dupla), seguindo a classificação apresentada por Fenaroli (1775). Para uma cadência simples, é necessária uma unidade métrica, para a cadência composta duas unidades e para a cadência dupla quatro unidades métricas.
} 
É assim, porque é assim que tem que ser: a retórica galante nos motetes de José Maurício, observada no uso da pedagogia dos partimenti, da gramática das schemata e da oratória musical

base à arte da improvisação" (Trilha Neto 2011, p. 105). Em síntese, sobre cada grau da escala um tipo diferente de acorde é colocado. Isto resulta em um processo de harmonização destes graus proporcionando uma condução de vozes com soluções de contraponto de forma mais precisa.

Dito isso, é importante ter em mente que todo o processo tinha um eixo: a relação consonância/dissonância dentro do conjunto escalar. Isso quer dizer que uma progressão considerada fundamental para mover uma melodia, como os graus conjuntos de uma escala, eram a base, também, para ensinar o uso da dissonância nos acordes "pontes". A esse modelo de harmonizar uma escala que se dava o nome de Regra da Oitava. E, por ela, os compositores definiam boa parte de sua harmonização, inclusive acordes mais dissonantes, modulações e, até mesmo, a alteração da harmonia de um grau dependendo do movimento melódico. Diante disso justificava-se o considerável espaço que a Regra da Oitava tinha nas lições, pois, para abarcar as variantes, toda e qualquer harmonia sobre a escala deveria ser discutida em dois movimentos, ascendente ou descendente. Não obstante, estas variações não afetam a ideia principal de que temos necessariamente dois graus, o $\hat{1}$ e o $\hat{5,11}$ que devem receber acordes na posição fundamental, ou seja, com a figura ${ }_{3}^{5}$. Os graus restantes, um tipo de acorde ${ }_{3}^{6}$ (Fig. 1).

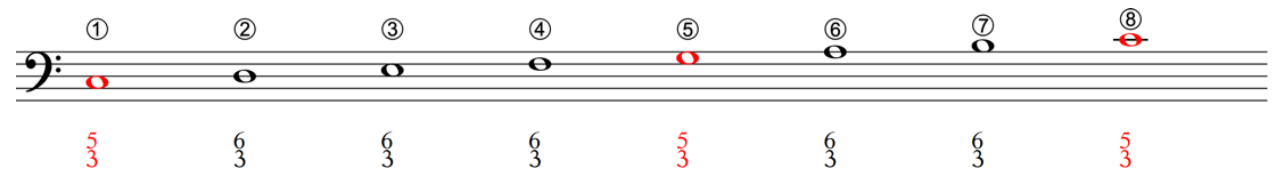

Figura 1: Regra da Oitava em sua apresentação mais rudimentar.

Porém, reiteramos, a Regra da Oitava não era uma cláusula pétrea dos fundamentos de harmonização das progressões do baixo. Porém, era importante o seu trato, pois entendendo qual o tipo particular de acorde com sexta pertencente a um determinado grau da escala, pode-se harmonizar diferentes progressões. Ademais, por meio de dissonâncias inerentes a cada grau pode-se orientar um acorde em qualquer tonalidade.

\footnotetext{
${ }^{11}$ A partir desse ponto usaremos os algarismos arábicos para determinar as notas como graus escalares; números romanos para determinar os acordes como funções dentro do sistema tonal. Para as análises pela teoria das schemata adotamos a notação de proposta por Gejrdingen (2007): números em cículos em branco para notas do baixo e números em círculos em negrito para notas do soprano.
} 
MUSICA THEORICA Revista da Associação Brasileira de Teoria e Análise Musical 2020, v. 5, n. 2, p. 74-141 - Journal of the Brazilian Society for Music Theory and Analysis@ TeMA 2020 - ISSN 2525-5541

A Regra da Oitava foi se transformando por um processo dinâmico, por estas possibilidades amplas de articular a harmonia. Com o passar do tempo, ela recebeu diversas versões, principalmente acrescentando notas aos graus harmonizados $\mathrm{em}_{3^{\prime}}^{6}$ como vemos no modelo de Regra da Oitava de Fenaroli (Fig. 2). Esse modelo, por exemplo, traz uma concepção de uso das dissonâncias mais intensas do que eram usadas por autores como Alessandro Scarlatti. E tais transformações não foram pontuais. Sempre no sentido de dar à Regra da Oitava atualizações sobre a relação dos acordes, e seus vínculos, à razão de temas como a presença das dissonâncias, os modelos se sucediam de mestres para mestres.
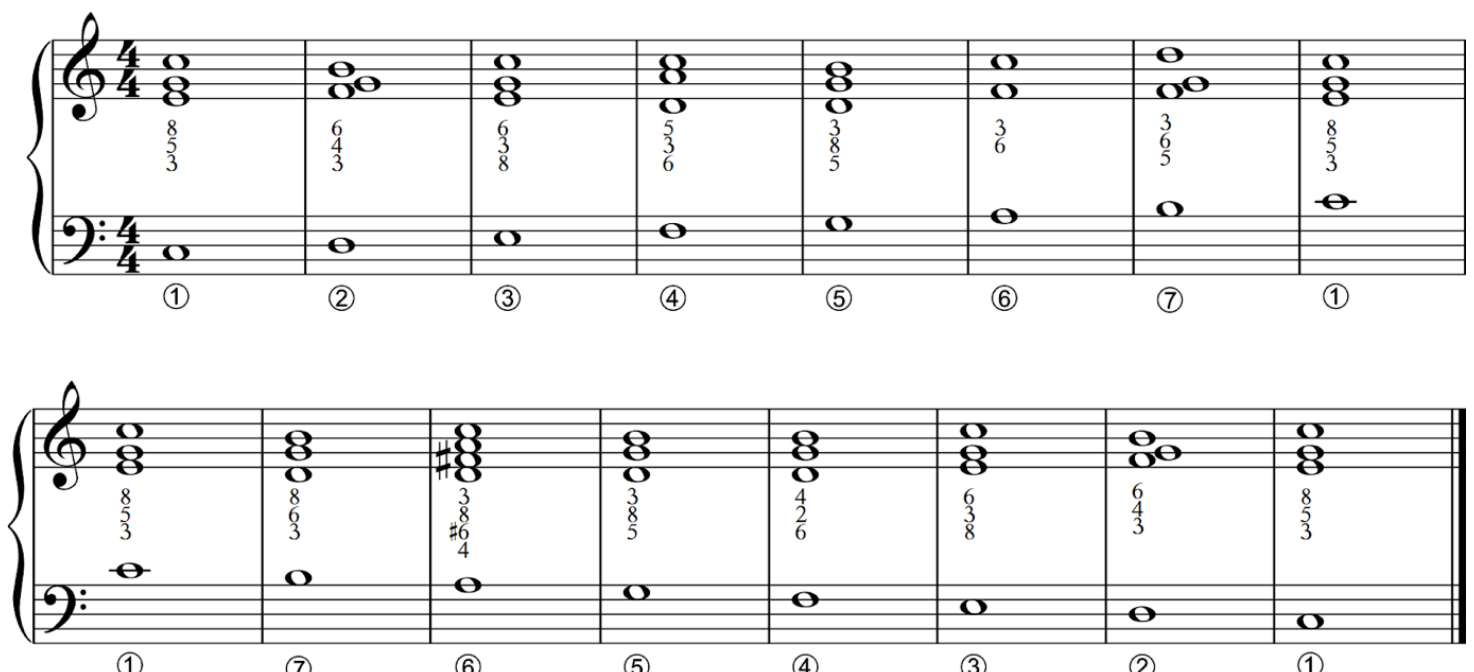

Figura 2: Regra da Oitava com base no modelo de Fedele Fenaroli (1730-1818), na edição de $1775 .{ }^{12}$

Porém, para este espaço, resta dizer que, além da harmonização dos graus conjuntos derivados da Regra da Oitava, outros movimentos de baixo eram estudados pelos alunos. Estes movimentos envolviam passagem com graus conjuntos e disjuntos, e deveriam receber uma figuração diferente da proposta pela regra padrão (nessa categoria, um dos esquemas mais comuns é a romanesca). Outrossim, os alunos aprendiam a construir acordes usando suspensões, que se referem às dissonâncias que são preparadas por consonâncias obtidas por meio de ligaduras de várias qualidades (sobre a quarta, a sétima, a nona e a segunda). Por fim, temos os elementos mais avançados que consistem

12 A figuração de François Campion (1686-1747) da escala maior é o modelo encontrado na maioria dos textos do século XVIII (Christensen 1992, p. 92), inclusive servirá de base para os mestres italianos, como este modelo de Fedele Fenaroli. 
na mutação de escala, denominados como terminazione di tono ou terminazione di grado. A este fundamento poderíamos, contemporaneamente, fazer um paralelo com nosso conceito de tonicização, pois, como diz Sanguinetti, "é uma atribuição temporária e localizada da função da tônica a um grau de escala subordinado" (Sanguinetti 2012, p. 159).

Evidentemente, os problemas que sucintamente apresentamos acima se estabeleciam como paradigmas que respondiam não só às gerações, mas, também, localizavam os conceitos de cada escola sobre a condução harmônica. No entanto, é interessante observar que alguns desses paradigmas que estão em tratados como os de Fenaroli e de Furno se apresentam em harmonizações de José Maurício. Logo, observando esses alinhamentos, podemos, inclusive, discutir sua música numa perspectiva da circulação dos conhecimentos, inclusive de forma datada.

É o que trataremos a partir desse ponto, pois, conhecendo os conceitos e, consequentemente, a forma como eram tratados, é possível ver questões doutrinárias de usos harmônicos e, mais que isso, a datação destes debates. Enfim, esse exercício comparativo coloca o musicólogo em uma posição parecida à dos arqueólogos.

\section{As relações com os processos criativos vistas pelos usos dos partimenti e schemata}

O ponto discutido acima, ou seja, as alterações de princípios básicos da Regra da Oitava em relação aos problemas coevos da harmonia, nos leva a uma questão. Qual é o espaço de criatividade, inovação ou mesmo de ruptura de um compositor galante? Poderíamos dizer que é da mesma dimensão de um compositor atual, no entanto, respeitando o despojo de uma erudição forjada na ideia dos universais, regida num princípio de pensamento retórico.

No entanto, é falacioso imaginar que por ser uma escrita retórica ela fosse desprovida de qualquer possibilidade de individualidade criativa ou inovação nas expressões semânticas da música. Esse é um ponto importante, pois para entendermos qual a qualidade e a validade de uma ação "inovadora", numa plataforma de saberes retóricos galantes, devemos compreender que havia todo um mecanismo que articulava o acervo expressivo. $\mathrm{O}$ compositor, ao assimilar uma poética de forte lastro de experiências expressivas que se consubstanciavam 
MUSICA THEORICA Revista da Associação Brasileira de Teoria e Análise Musical 2020, v. 5, n. 2, p. 74-141 - Journal of the Brazilian Society for Music Theory and Analysis @ TeMA 2020 - ISSN 2525-5541

nas estruturas representativas convencionadas, assimilava também os mecanismos para dotar o seu uso de uma plasticidade dinâmica. Somente nessa perspectiva de referenciais profundas, enraizadas desde a formação mais inicial, que podemos vislumbrar esse jogo entre tipos de uma mesma espécie (os ideais e específicos que Hatten denomina como tipos e tokens) que permite todo tipos de articulação expressiva. Inclusive, sem compreender essa propriedade de modulações sutis nos padrões aprendidos, há uma diminuição considerável do alcance do processo hermenêutico para compreendermos as estratégias discursivas.

É neste ponto que podemos, entre outras perspectivas, levar a discussão para as bases dos partimenti e esquemas de contraponto. No entanto, temos de assumir inicialmente que toda a trama harmônica, métrica e de textura está pensada a partir de pontos referenciais. No caso da harmonia, esses referencias estão constituídos na ideia de combinação de padrões. Padrões que se revelam muito pela progressão de baixo, e não na perspectiva associativa de acordes (como na harmonia funcional).

Daqui se desdobra outro ponto que devemos compreender e que nos abre para a rede de sentidos permutáveis, que chamamos de Retórica: os baixos não se projetavam por si só. Ao serem ensinados conjuntamente com o movimento contrapontístico do canto, os baixos desvelavam "marcas" sonoras, ou seja, eram elementos de correlações de sentido que deveriam ser inteligíveis a um público educado. E esse era o segredo da pedagogia napolitana. Ao mesmo tempo que ensinava harmonia e forma, induzia o aluno a pensar o ethos de cada estrutura. Em outras palavras, a pedagogia do partimento tratava da manutenção e projeção de um capital cultural sonoro que sustentava redes de sociabilidade cujo lastro era a tradicionalidade de uma estrutura musical.

Voltando ao exemplo da romanesca (veja nota 4), devemos entender que ela era mais do que uma forma de harmonizar uma escala descendente. Era uma marca sonora que remetia a uma significação, ou melhor, a muitas significações, se considerarmos a sua capacidade de "abertura de sentidos" a partir de uma matriz específica (e aqui remetemos ao que já expusemos sobre o conceito da estética do pólipo). Não por nada, esse método de ensino se confunde com o Antigo Regime, na medida que compreendia dois pontos articulados: as marcas de distinção, e essas marcas como reveladoras de um racionalismo cujo cognitivo estava na certeza dos universais. 
É assim, porque é assim que tem que ser: a retórica galante nos motetes de José Maurício, observada no uso da pedagogia dos partimenti, da gramática das schemata e da oratória musical

Por um lado, partimenti não podem ser confundidos como a composição em si, assim como as schemata. Partimenti são suportes pedagógicos; schemata são estruturas musicais referenciais que se vinculavam à organização da forma através da harmonia. No entanto, ambos, cada qual com sua função, representam a base de um raciocínio retórico. Isso vale, também, para o que pode ser trabalhado como alteração, negação, ou mesmo obliteração de sentido.

Outro problema é a forma como essas estruturas eram usadas no processo criativo. Se é bem verdade que os esquemas deveriam, em tese, ter inteligibilidade, isso não era uma regra. Aliás, era mais comum usar esses esquemas obliterados ou mesmo fragmentados. Isso porque, a ideia de que haveria "sempre uma ordem" para encadear esquemas, ou mesmo alguma ordem sintática dos esquemas (a romanesca para os inícios, por exemplo), era suficiente para que fragmentos ativassem a compreensão do movimento musical, inclusive para tornar as alterações como elementos de significação. Ou seja, essas estruturas, apesar de sintáticas, entravam nas estratégias expressivas dos compositores.

Aqui podemos desdobrar algo de um incômodo contemporâneo diante das análises retóricas. Vemos que muitos desconsideram o impacto dos esquemas justificando que a escrita criativa teria uma natureza contrária a esse uso esquemático. Isso é uma falsa consciência, pois mesmo alterados, a lógica retórica desses elementos continuava presente, até para efeito de um agenciamento virtual. Isso porque, qualquer elemento retórico poderia ser usado não somente na relação primária de sua estrutura, mas como gatilho de uma experiência auditiva rememorada. Por outras palavras, a epistemologia do processo criativo galante era tão enraizada no trato de seus objetos de significação que absorvia as obliterações de todas as ordens. Inclusive porque o problema da música galante era a oratória, e não a realização dos protocolos do sistema. Esse é um aspecto fundamental da música galante: ter o máximo possível de inteligibilidade, mesmo no emaranhado de gestualidades, esquemas, figuras, enfim, estruturas simbólicas convencionadas que articulava.

Em síntese, nada exigia que uma composição fosse totalmente feita a partir do encadeamento modular de esquemas de contraponto; porém, sem eles, o sucesso do projeto em termos de comunicabilidade poderia naufragar. Desta forma, os esquemas (e aqui o partimento como parte da projeção dos esquemas de contraponto) são naturais na formação da estrutura harmônica. Porém, 
MUSICA THEORICA Revista da Associação Brasileira de Teoria e Análise Musical 2020, v. 5, n. 2, p. 74-141 - Journal of the Brazilian Society for Music Theory

reiteramos, os compositores subvertiam regras, alteravam semânticas, mas, também, apresentavam esquemas tal qual nos cadernos de instrução. E isso poderia denotar muitas coisas no projeto expressivo, desde decoro, perícia profissional, intertextualidades diversas, citações, paródias ou até mesmo ironias.

Desta forma, é natural vislumbrarmos muitas fórmulas retóricas in natura, na música galante, assim como manipulações. Todas sustentadas na oratória. $\mathrm{Na}$ música de José Maurício esse fenômeno não foge à regra. Podemos tranquilamente mostrar usos de esquemas de contraponto usados escolarmente e outros alterados. Podemos, ainda, associá-los aos projetos expressivos e, inclusive discutir questões da "genética" musical ao nos depararmos com progressões que revelam elementos aprendidos das lições dos partimenti.

\section{Discutindo o impacto do aprendizado do partimento na música de José Maurício: primeiro estágio, a Regra de Oitava}

Como vimos, a Regra de Oitava é um dos estágios primários, porém essencial, do aprendizado do partimento. Como já afirmamos acima, a Regra de Oitava condiciona o aprendizado das funções harmônicas nos graus da escala, mas, também, questões sobre as dissonâncias acrescentadas e suas localizações nas progressões do sistema.

Assim, antes de entrarmos no estudo do uso da Regra da Oitava por José Maurício Nunes Garcia, faz-se necessário sublinhar um ponto cardinal da Regra da Oitava, qual seja, as dissonâncias nos acordes intermediários aos $\hat{1}$ e $\hat{5}$ graus (para ter a dimensão do problema compare as Fig. 1 e 2). Isso é importante porque localiza o pensamento harmônico de José Maurício em face da discussão coeva.

Dito isso, vejamos um fragmento do motete Improperium expectavit cor meum (ca. 1799) (Fig. 3).13

\footnotetext{
${ }^{13}$ Com base na Fig. 3, e seguindo o modelo proposto por Robert Gjerdingen (2007), indicamos a presença das schemata pelos chaveamentos e barras acima ou na vertical. Além disso, a melodia, ou voz externa aguda do schema, é representada pelo algarismo arábico dentro de um círculo preto. Um algarismo arábico dentro do círculo branco serve para representar o baixo. Vale salientar, ainda, que as análises se referem à "tonalidade" no presente momento do schema e não à tonalidade do trecho ou da obra como analisamos nos dias atuais. Como dito anteriormente no
} 
É assim, porque é assim que tem que ser: a retórica galante nos motetes de José Maurício, observada no uso da pedagogia dos partimenti, da gramática das schemata e da oratória musical

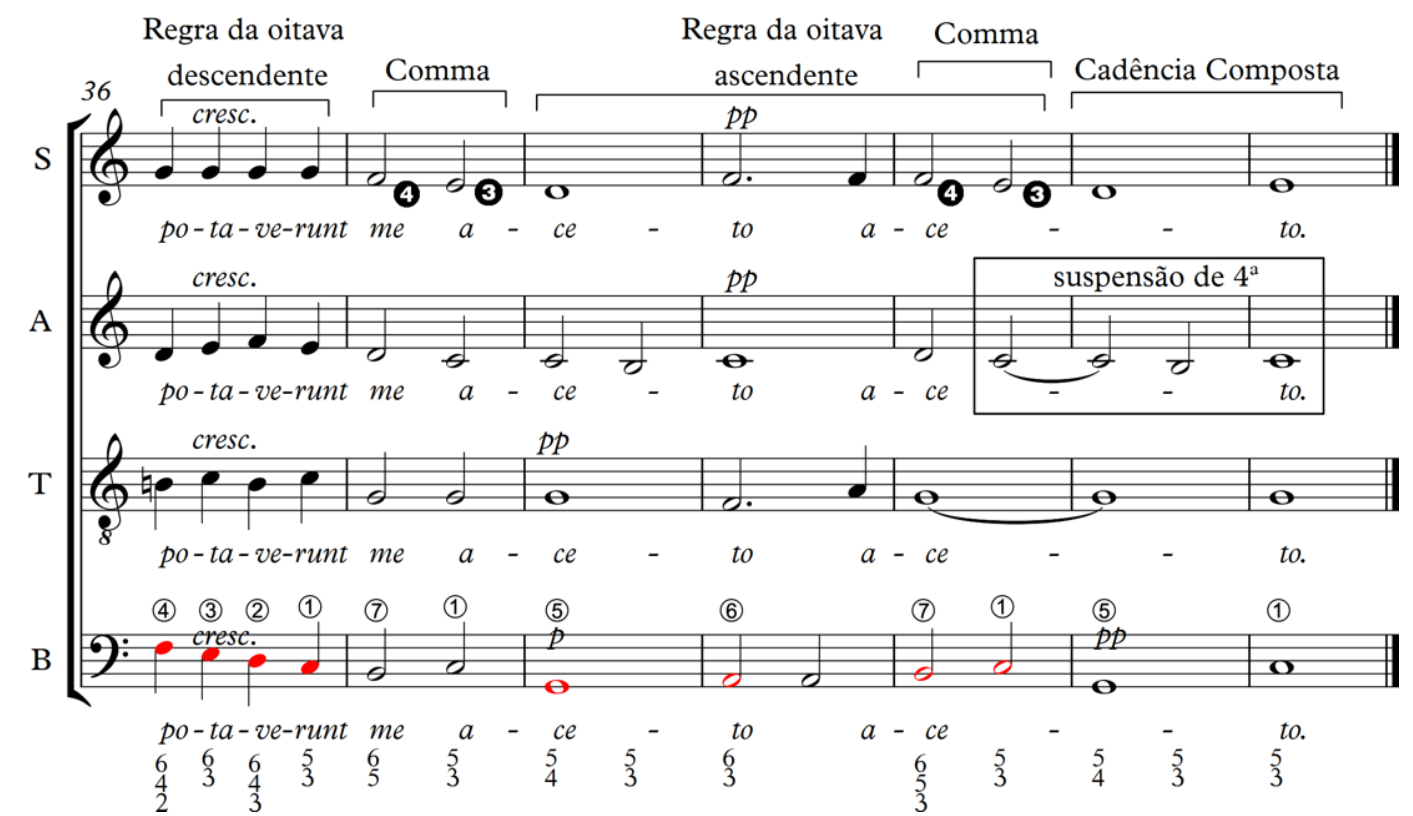

Figura 3: Peroratio do motete Improperium expectavi cor meum, de José Maurício Nunes Garcia (ca. 1799).

Neste trecho vemos a harmonização de uma progressão de baixo que forma um movimento escalar descendente, de Sol a Sol. Para tanto, se vale, numa primeira parte, de um fragmento escalar usando as notas (4), (3), (2), (1), da escala de C (notas em vermelho). Essa progressão poderia ser harmonizada de muitas formas, como, por exemplo, por um esquema de romanesca ou por diversas fórmulas de progressão (por quartas, quintas, sextas e sétimas - Figs. 4 e 5). No entanto, por uma perícia que reconhecia funções e características expressivas dos elementos retóricos, a opção pela romanesca, por exemplo, encontraria a limitação de ser um esquema bastante apto para iniciar um trecho musical e, inclusive, para um projeto expressivo com certas especificidades de etos eufórico, como as danças pastoris. Como esse trecho é uma peroração e tem como função a afirmação da tonalidade, a escolha recaiu sobre a Regra da Oitava, pois é justamente a mais natural para tal, seguindo o raciocínio galante.

Aqui já podemos afirmar algo da estética galante: as escolhas eram determinadas por suas restrições. Nesse caso, a Regra da Oitava (assimilada desde a primeira formação escolar) era uma opção natural ao caráter do trecho,

texto, a ideia de tonicização era muito frequente e se associava aos outros elementos citados como parte do projeto discursivo. 
MUSICA THEORICA Revista da Associação Brasileira de Teoria e Análise Musical 2020, v. 5, n. 2, p. 74-141 - Journal of the Brazilian Society for Music Theory and Analysis@ TeMA 2020 - ISSN 2525-5541

ou seja, sua escolha se deu pelo que se quer da regra dentro do projeto expressivo e das estratégias de argumentação.

Desdobrando o problema, devemos compreender que era da perícia do compositor saber as funções dos esquemas. Logo, a escolha da Regra da Oitava deve ser analisada na perspectiva de consolidar a finalização tonal, pois o campo da tônica deveria ser reiterado por movimentos assertivos de forte caracterização. Uma das estratégias comuns era justamente criar um movimento de reiteração escalar, como fez José Maurício.

Especificamente, ele constrói essa peroração partindo de movimentos oblíquos (nas vozes do baixo e do alto), articulados sobre a nota da dominante. $\mathrm{Na}$ primeira parte (cc. 36 e 37), escreve no baixo um movimento num espaço quartal que chega à nota si, o (7). No entanto, a partir desta nota (7), c. 37) faz um contrafluxo rítmico através de duas mínimas enlaçadas em movimento contrário ao movimento das semínimas que as antecederam. É um freio (uma comma) para retomar a escala. Na sequência, reitera o movimento em direção oposta (Fig. 3, cc. 38-39). Culmina a peroração em uma cadência composta determinada por um movimento de suspensão de quarta no alto (é a nota Si da resolução dessa suspensão que caracteriza a cadência composta).

No entanto, e apenas por questão argumentativa, é necessário dizer que esse esquema, neste trecho, não cria um espaço semântico específico. Aqui, a Regra da Oitava é, sobretudo, um recurso gramatical para a questão formal. Isso não quer dizer que esquemas de contraponto não possam assumir funções semânticas.

Apenas para sustentar a argumentação entre imbricações das funções semânticas e sintáticas, vejamos a regra usada num mesmo ambiente marcado pela reflexão da morte, como é um motete dentro da Semana Santa. Em um trecho que fala sobre a redenção que advém da morte física, José Maurício opta por uma harmonização da Regra da Oitava com função mais semântica do que o fez no motete supracitado. Trata-se do inicial do Ofício Fúnebre de 1816, obra composta para os funerais de Dona Maria I. ${ }^{14}$ A harmonização usada no

${ }^{14} \mathrm{Na}$ Oratória Clássica, a forma de abertura é fulcral, pois acreditava-se que o orador ganhava a audiência nas primeiras palavras. No caso da música, o compositor geralmente apresenta os principais materiais do argumento, a começar pelo campo afetivo. Assim, uma harmonização suave (imaginando sempre a oposição tradicional entre suave e áspero, que se projeta da ópera italiana desde Monteverdi) para encerrar a primeira frase de um ofício fúnebre é bastante eloquente para ouvidos treinados. Principalmente considerando o que vimos trabalhando sobre 
É assim, porque é assim que tem que ser: a retórica galante nos motetes de José Maurício, observada no uso da pedagogia dos partimenti, da gramática das schemata e da oratória musical

fechamento da primeira frase do Ofício é uma progressão de sextas sobre a Regra da Oitava, ou seja, todos os acordes, com exceção do I e o V grau do penúltimo acorde, estão na primeira inversão (Fig. 4). Essa configuração (com profunda referencialidade das sonoridades de falso-bordão) é bastante usada em trechos pastorais (Fig. 5). Não bastasse isso, José Maurício escreve essa harmonia associada à uma configuração rítmica de simbolismo da serenidade do destino, mesmo trágico. Em outras palavras, a harmonia reforça a ideia do texto - "Eu acredito na minha vida redentora" (Credo redemptor meus vit) - , e, ainda mais, incorpora uma harmonia que descortina uma tópica pastoral, esta reconhecidamente associada ao dogma da redenção. Lembremo-nos, Maria "jaz em jardins floridos" e foi levada aos céus imaculada, ou seja, "pura", em estado de Natureza.

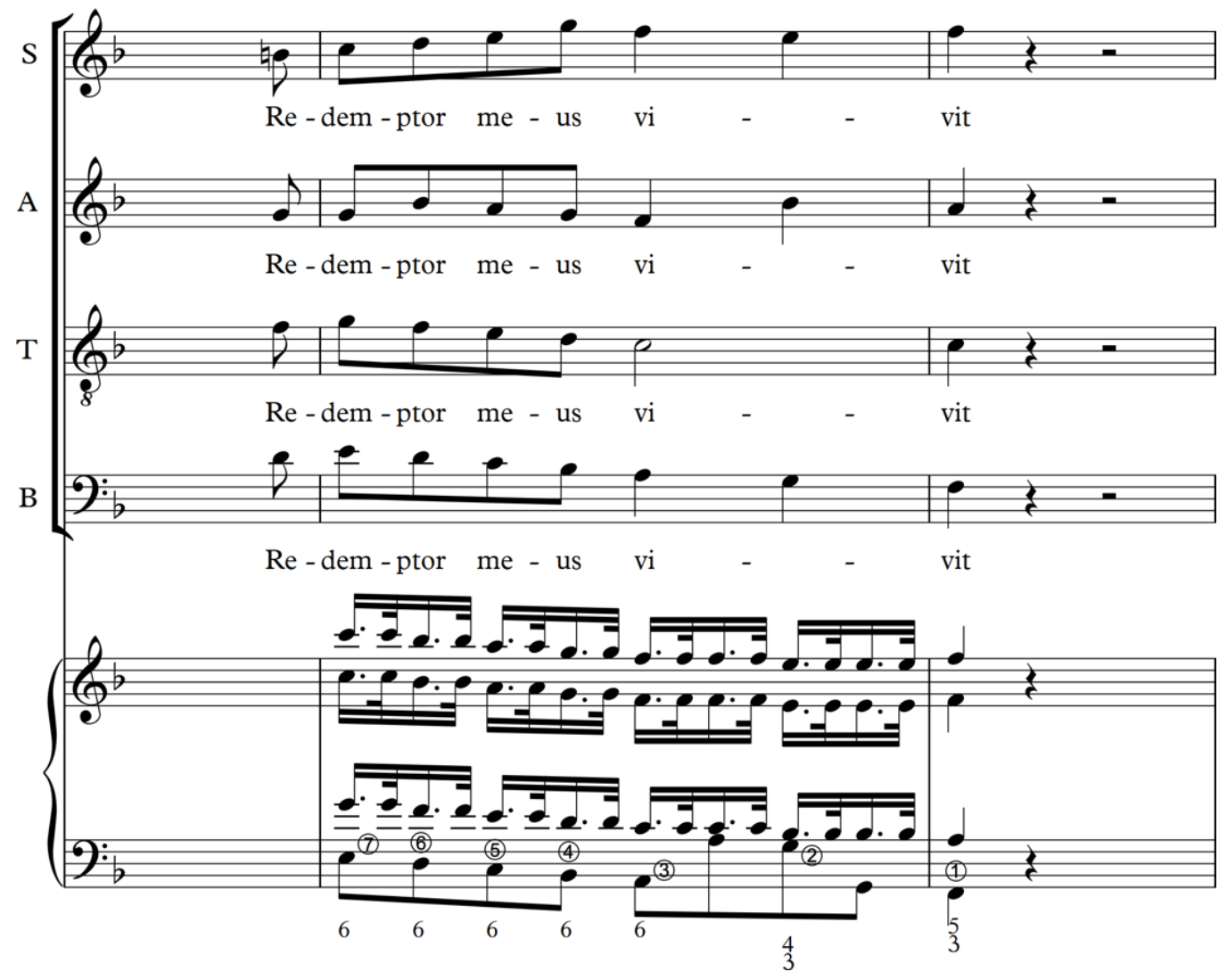

Figura 4: Regra da Oitava em sexta em José Maurício Nunes Garcia, Ofício 1816 (c. 7-8).

a doutrina mariana que funda José Maurício, onde a morte, principalmente a Boa Morte, é um momento culminante da renovação espiritual. 
Aproveitando o exemplo do Ofício, e saindo das relações semânticas e sintáticas que os partimenti podem servir, vejamos a plasticidade da Regra da Oitava por outro elemento: o alinhamento dos saberes com os manuais de partimenti coevos. Seguindo tabelas amplamente discutidas por Giorgio Sanguinetti (2012, p. 129), vemos que algumas soluções de José Maurício alinham com ensinamentos estabilizados a partir da escola durantisti (de Francesco Durante), notadamente pelo trabalho de Fedele Fenaroli. Saberes que recolhemos em incontáveis obras, mas aqui sublinhamos um trecho de Haydn para exemplificar o que estamos tratando: a universalidade das resoluções harmônicas aprendidas no processo esquemático dos partimenti. Isso podemos comprovar, por exemplo, nos primeiros compassos do I movimento da Sinfonia n. 104. Haydn, assim como José Maurício no excerto acima (Fig.4), usa a Regra da Oitava com progressão em sextas. E, como José Maurício, Haydn usa essa harmonia para construir um ambiente pastoral (Fig. 5).

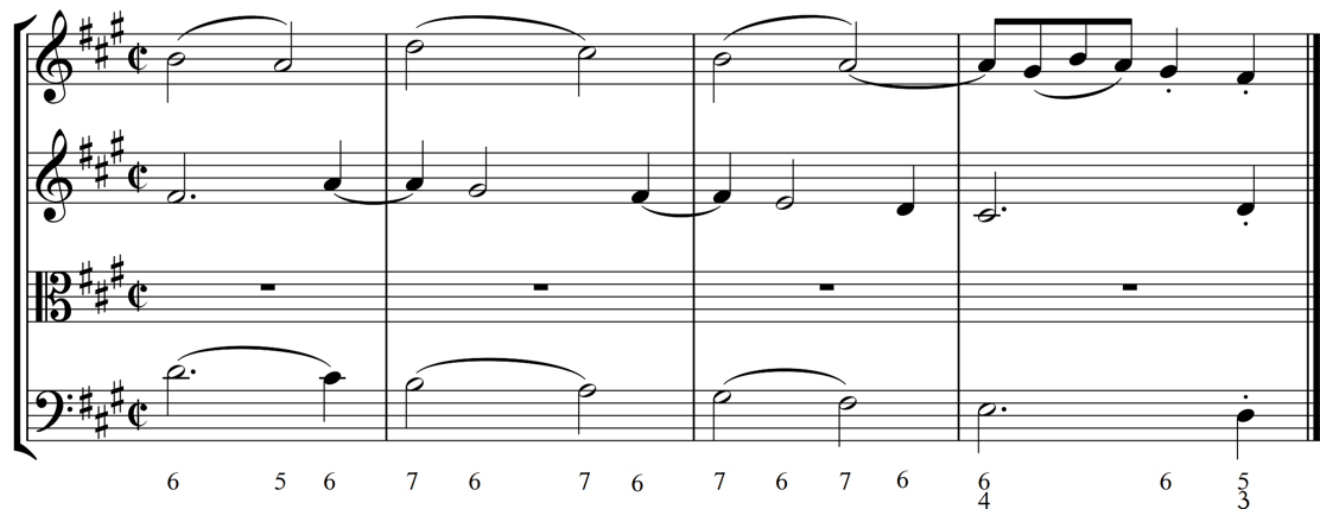

Figura 5: Regra da Oitava em sexta em Joseph Haydn, Sinfonia n. 104, I mvt., Allegro (c. 20-23).

Logo, poderia surgir a seguinte questão: era uma transferência de modelo direto de Haydn para José Maurício pelo estudo da sua obra, como sugere a nossa tradicional musicologia? Não, era o compartilhamento dos saberes sustentado no processo de aprendizado, tanto da gramática quanto da retórica.

Dito isso, vamos a outro ponto: como observar alinhamentos diretos de discussões sobre harmonia dentro da música de José Maurício usando as ferramentas do partimenti? Simples, comparando os usos dela com a evolução da Regra da Oitava. Isso porque, entre outras questões, os mestres do ensino dos partimenti incorporavam em suas lições elementos de atualização, como dos lugares e qualidades das dissonâncias. 
É assim, porque é assim que tem que ser: a retórica galante nos motetes de José Maurício, observada no uso da pedagogia dos partimenti, da gramática das schemata e da oratória musical

Voltemos à Fig. 3 para vermos isso. A harmonização do c. 36 é feita usando o acorde de ${ }_{4}^{6}$ no IV grau e de ${ }_{4}^{6}$ no II grau. É um claro tensionamento que sobrecarrega de dissonância um movimento quartal escrito em um curto espaço. Concomitante a isso, há um movimento expressivo através de uma extensão do movimento harmônico por uma figura de retórica denominada comma. Sua função, como se pode ver no c. 37, é brecar o que poderia ser um movimento progressivo tonicizado em $\mathrm{G}$, o que para uma peroração seria inviável. A comma então se dá no acorde ${ }_{3}^{5}$ em Dó (I grau), para retomar o movimento cadencial a partir do acorde do V grau. Não bastasse isso, na sequência José Maurício novamente harmoniza o baixo pela Regra da Oitava, agora ascendente (c. 38-40). Aqui, o compositor utiliza a sequência (5), (6), (7) e (1) da Regra, com a nota no cantus caracterizando novamente uma comma, que parte do movimento contrário da primeira parte. Por fim, para finalizar o motete, o Padre se utiliza da cadência composta entre os compassos 41-42, proveniente de uma suspensão de quarta, preparada pela oitava.

Desta forma, comparando as diversas escolas e soluções para a Regra da Oitava, parece que José Maurício assume alguns paradigmas durantisti, assim como transpareceu na Regra da Oitava usando uma progressão em sextas. Primeiro, por um maior tensionamento da progressão pelo uso de acordes com sétimas. Segundo, porque o acorde ${ }_{3}^{6}$, tão debatido pelos teóricos do período, aparece com a quarta na voz do alto, o que não era uma presença comum em épocas anteriores à segunda metade do século XVIII. Aliás, esse problema afeta, entre outros, o II grau. Dizendo de outra forma, a Regra da Oitava em José Maurício se alinha com conceitos difundidos por Fenaroli (Fig. 2), onde este grau é harmonizado por um acorde ${ }_{3}^{6}$, tanto na forma ascendente quanto na descendente.

Logo, essa harmonização que aparece em José Maurício num motete de 1799 era um uso datado, ou seja, vinculado a questões já presentes em tratados a partir de 1775, mas não antes. Isto quer dizer que há um sincronismo, pois alguns princípios relacionados ao uso de dissonâncias foram, primeiro, acrescentados aos acordes paulatinamente, sendo o acorde sobre o II grau um dos mais importantes. Segundo, justamente esse grau (II) é um ponto de discórdia entre os seguidores das escolas de dois importantes mestres do partimento, Francesco Durante (1684-1755) e Leonardo Leo (1694-1744). Inclusive, Gjerdingen aborda 
MUSICA THEORICA Revista da Associação Brasileira de Teoria e Análise Musical 2020, v. 5, n. 2, p. 74-141 - Journal of the Brazilian Society for Music Theory and Analysis@ TeMA 2020 - ISSN 2525-5541

essa polêmica destacando que o "relato das diferenças técnicas entre os Durantisti e Leisti preocupou-se se deveria ou não tratar o intervalo de quarta acima do segundo grau da escala como uma consonante" (Gjerdingen 2007, p. 234).

Assim, o aspecto a ser sublinhado nesse uso que vemos em José Maurício é o alinhamento ao que a escola durantisti assumia como ideia do intervalo de $4^{\mathrm{a}}$ acrescentado no II grau, ou seja, para fortalecer o caráter dissonante do acorde. Sua função era criar uma tensão em direção ao acorde sobre o III grau, ao subir, e para o I grau no fechamento da Regra ao descer, como podemos ver na Fig. 6.

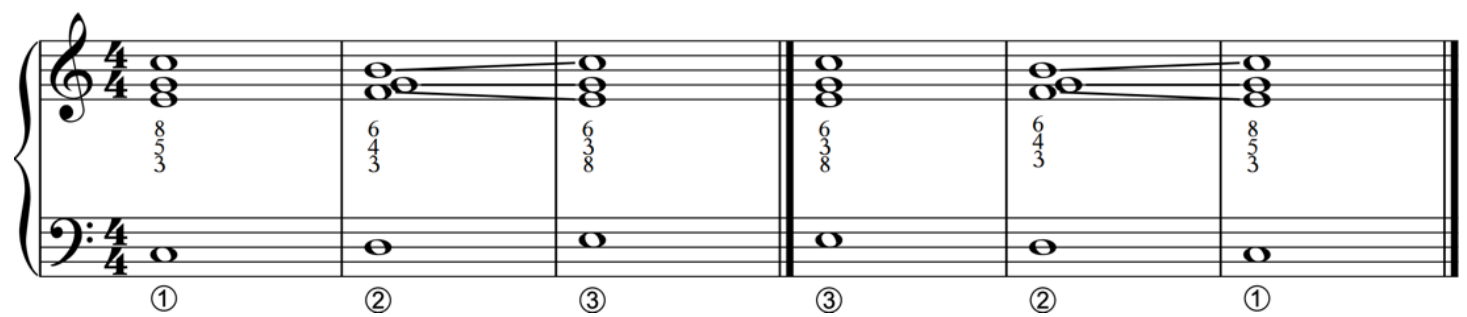

Figura 6: Tratamento contrapontístico no segundo grau da escala, segundo Durantisti.

Ainda em relação à utilização da Regra da Oitava na Fig. 3, percebemos o tratamento dado aos graus IV (c. 36) e VI (c. 39). No caderno de Giovanni Furno (1817), antes da apresentação da Regra da Oitava, o autor detalha quais os movimentos cada grau da escala pode fazer, e qual a figuração receberá. Neste sentido, os acordes que sofrem as alterações mais radicais seriam o IV e o VI. Na Fig. 7, vemos as alterações propostas pelo mestre. Afirma Furno que se o IV grau caminhasse em direção ao $\mathrm{V}$ receberia um acorde ${ }_{3}^{6}$, e se ele fosse em direção ao III grau, precedido pelo $\mathrm{V}$, receberia a figura ${ }_{2}^{6}$. Segue mostrando que se o IV grau não fosse para o $\mathrm{V}$, ele receberia um acorde ${ }_{3}^{5}$. Em relação ao VI grau, ao caminhar para o VII grau, deveria figurar como ${ }_{3}^{6}$ e o VII um ${ }_{3}^{6}$, para evitar paralelismos indesejáveis. Na direção contrária, ou seja, o VI grau caminhando para o V grau, deveria receber um acorde ${ }_{3}^{\# 6}$. Isso porque, o aumento da sexta proporcionaria a criação de um acorde "dominante" para o V grau. Ainda seguindo Furno, seu tratado novamente apresenta um acorde não proveniente da Regra: um VI grau que não caminha para o V grau, e que receberia uma figuração ${ }_{3}^{5}$. Por fim, no VII grau o baixo figurado também deveria variar conforme a direção, sendo que ao subir recebe um acorde ${ }_{3}^{6}$, deveria descer com a figuração ${ }_{3}^{6}$. 
É assim, porque é assim que tem que ser: a retórica galante nos motetes de José Maurício, observada no uso da pedagogia dos partimenti, da gramática das schemata e da oratória musical
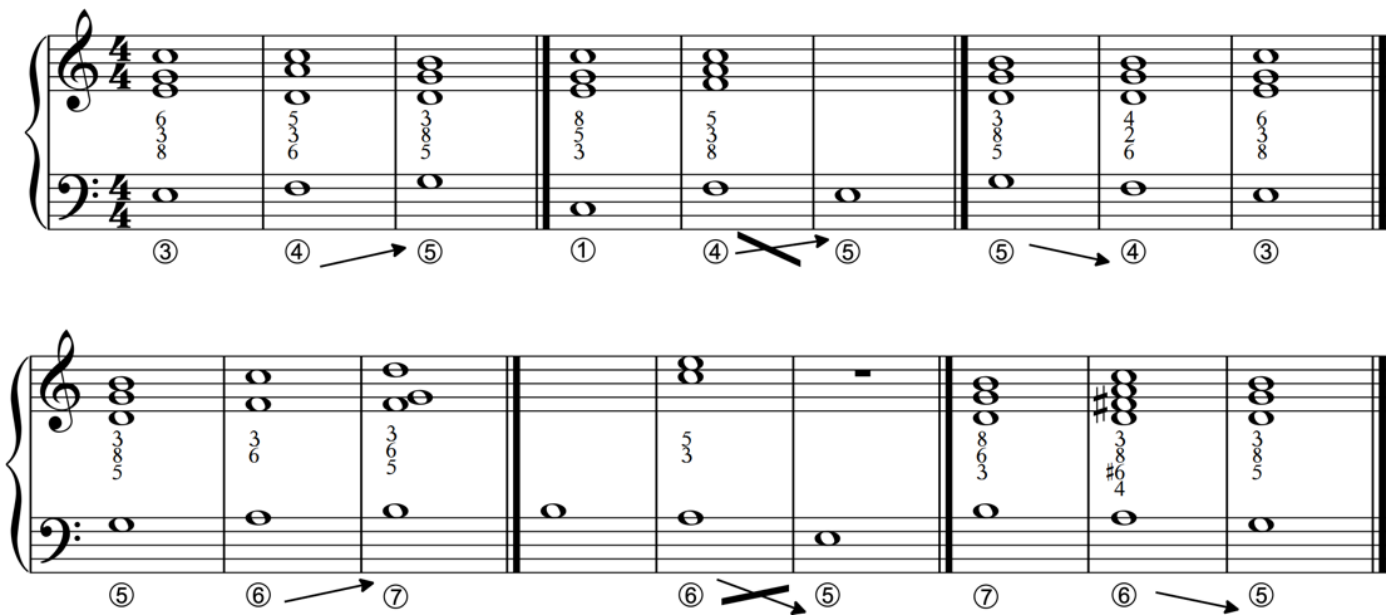

Figura 7: Variações da regra da oitava nos graus IV e VI conforme os movimentos do baixo.

Por outras palavras, questões de alinhamentos das escolhas composicionais não são apenas questões criativas, mas, também, identitárias do tempo e das doutrinas. Tratamos de mostrar como um pequeno trecho revela inúmeras questões. Vimos como o uso de uma mesma regra revela problemas das fronteiras entre semântica e sintática; desvela a diversidade de modelos harmônicos e, por último, problemas dos acordes, numa relação das questões das progressões harmônicas. Ademais, esses problemas surgem para a contemporaneidade, desencaixada que é dos modelos epistemológicos e das metodologias pedagógicas comuns ao Antigo Regime. Para o compositor "do tempo", todos estes problemas estavam automatizados nas práticas cotidianas. Práticas, aliás, que expandia o problema para além dos partimenti.

\section{Para além dos partimenti}

No item acima tratamos de expor como uma ferramenta pedagógica - $\mathrm{o}$ partimento - se projetava nos processos criativos dos compositores. A Regra da Oitava é uma das matérias que melhor exemplifica as fronteiras entre o que se aprendia nos bancos escolares e o exercício da profissão. Porém, por ser uma estratégia de ensino que condensava muitos saberes, principalmente esquemas de contraponto (schemata) e a forma musical, era natural que fragmentos de partimenti ora ou outra sustentassem estruturas harmônicas de forma escolar, como se fosse essa a finalidade. 
MUSICA THEORICA Revista da Associação Brasileira de Teoria e Análise Musical 2020, v. 5, n. 2, p. 74-141 - Journal of the Brazilian Society for Music Theory and Analysis@ TeMA 2020 - ISSN 2525-5541

No entanto, é importante ter em mente que, embora os partimenti dessem fundamentos para a composição, eles não se projetavam automaticamente nas obras por diversas questões, mas principalmente, porque eles não circunscreviam pedagogicamente problemas como a relação entre a gramática musical e a representação de afetos. Essa parte do conhecimento era desenvolvida como "faculdade da retórica", e a ferramenta pedagógica era a imitatio. Pela disciplina da Retórica se articulavam muitos conhecimentos, desde o trato de questões literárias (como os gêneros literários, as métricas poéticas, as estratégias de discurso), até questões propriamente musicais, como os esquemas de contraponto, a forma e as figuras de retórica. Também é sob essa faculdade que os problemas de disposição dos elementos musicais encontravam-se com a lógica da oratória, que expandia o problema para as relações das estratégias de enunciação.

Dito isso, é necessário vislumbrar a força dessa estrutura de formação e legitimação. É por ela, ou seja, pela Ars Rhetorica, que uma cosmovisão se desdobrava como epistemologia e articulava a superestrutura sociopolítica cultural do Antigo Regime. Em outras palavras, é pela perícia da retórica que não só todo um acervo simbólico era assimilado, mas garantia, pelo compartilhamento de um capital simbólico, um vínculo ideológico que unia diversos agentes até mesmo em lugares limítrofes dos domínios europeus coloniais. Este não só se alinhava par a par com seus congêneres das principais metrópoles, mas era capaz de criar estratégias oratoriais válidas para um público disperso, inclusive de uma corte exiliada.

Por outro lado, é por causa da retórica, também, que surgiam processos de digitais próprias, muitas vezes feitas por pequenas sutilezas no uso das estruturas assimiladas. Sutilezas construídas em associações de esquemas, usos de tonalidades e/ou figuras, métricas etc. No entanto, elas não entravam nas fronteiras do estranhamento, pois estavam sempre atentas ao que uma escuta educada poderia modular na direção de uma compreensão específica no processo de agenciamento de enunciação. Mesmo nos limites, essa música se valia dos suportes de uma linguagem construída num capital cultural sólido, tradicional e capilarizado no que se entendia como ética cortesã. 
É assim, porque é assim que tem que ser: a retórica galante nos motetes de José Maurício, observada no uso da pedagogia dos partimenti, da gramática das schemata e da oratória musical

\section{A ars combinatória para um discurso sobre o dogma redentor da Paixão}

Como vimos discutindo, todo projeto expressivo dentro do universo galante trabalhava com dois desafios: a referencialidade e o decoro. Numa sociedade cortesã, a referencialidade legitimava a inteligibilidade e o decoro, a validade. Isso nos leva a um grande desafio na análise da música galante, isso porque todo e qualquer trecho é passível de potencializar questões expressivas. Isso significa não só uma relação dos elementos musicais convencionados numa perspectiva interna de uma unidade musical (perspectiva intramusical), mas, também, extramusical (o que esses elementos remetem a questões simbólicas "fora" da música, como a representação de um ambiente, sentimento ou ação).

Nas páginas seguintes trataremos de mostrar que cada um dos parâmetros do discurso (tonalidades e harmonias; métricas e esquemas de contraponto; figuras de linguagem) eram coordenados para construir um discurso. Faremos isso mostrando cada parâmetro em separado para, depois, discuti-los a partir das estratégias do compositor em face aos problemas postos pela relação música, texto/contexto e lugar.

\section{Das escolhas harmônicas}

Uma das questãos fundamentais para qualquer projeto expressivo se dava no campo harmônico, inclusive considerando como passo inicial a escolha da tonalidade. Esse passo é o que dá início ao entrelaçamento de muitos elementos expressivos. Não porque a tonalidade fosse a mais importante dos parâmetros retóricos, uma vez que todos os elementos expressivos são articulados numa relação da parte com o todo. No entanto, ela dá suporte ao afeto de forma determinante. Em termos práticos, uma mesma gestualidade rítmica em Ré maior é absolutamente diferente em Sol menor. Estas relações afetivas das tonalidades, aliás, eram domínios retóricos dos compositores galantes.

Dito isso, no motete em questão - Improperium expectavi cor meum de José Maurício Nunes Garcia - a escolha da tonalidade em C é por si é um significante. Ainda mais se, em poucos compassos, o compositor escreve indicações claras de que essa tonalidade é efêmera. Vejamos o começo do motete, observando a harmonização escrita por José Maurício (Fig. 8, c. 1-7). 


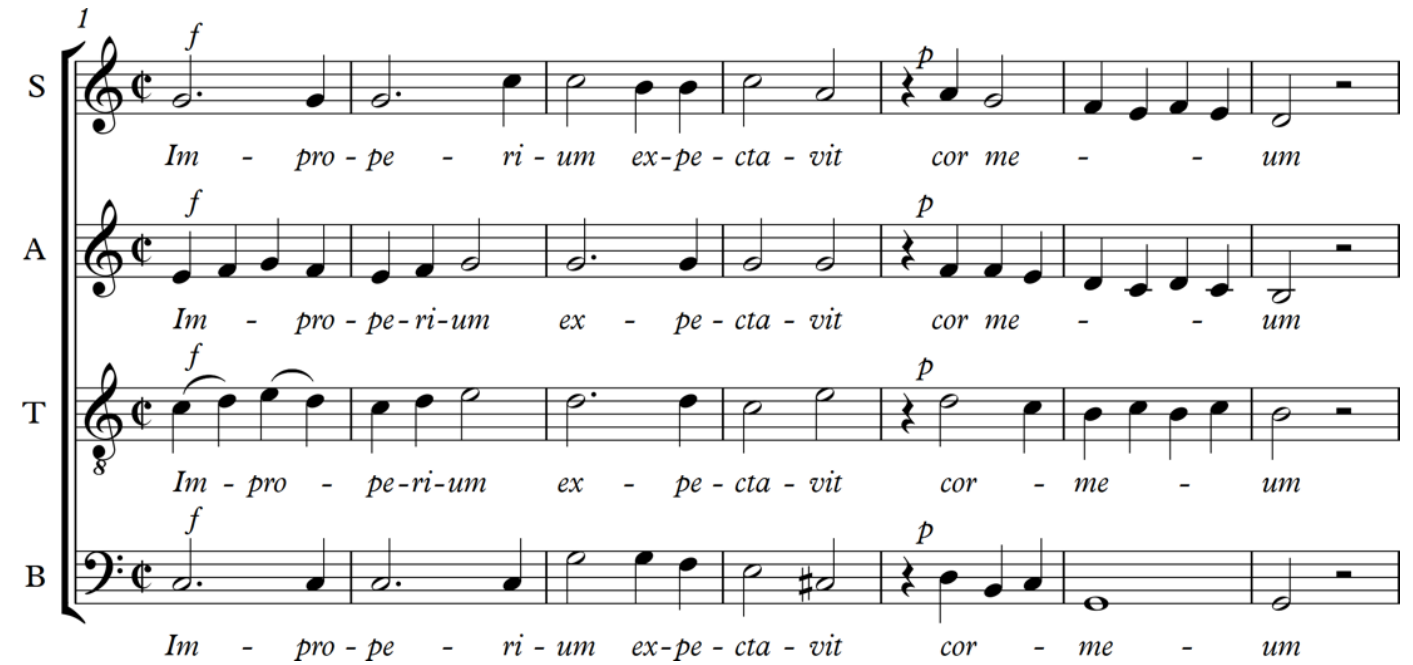

Figura 8: Improperium expectavit cor meum - c. 1-7.

Este trecho, aos olhos do analista moderno, está no âmbito de C. A progressão harmônica em termos de análise de graus seria $\mathrm{I}-\mathrm{V}_{8-7}^{4}-3-\mathrm{I}_{6}-\mathrm{V}_{5}^{6} / \mathrm{V}-$ $\mathrm{ii}_{3}^{5}-\mathrm{V}_{5}^{6}-\mathrm{I}-\mathrm{V}$, ou seja, uma progressão que conclui numa cadência suspensiva. No entanto, para o músico do século XVIII, ainda preso aos conhecimentos dos deslocamentos hexacordais (denominado como solfejo italiano), e da escrita por esquemas, essa progressão guarda vários detalhes que não só dizem respeito somente a esse movimento, mas a todo o enunciado da unidade musical.

O primeiro elemento saliente para esse problema aparece já no quarto compasso. Em termos contemporâneos, diríamos que ali ocorre uma dominante individual de Ré, mas no século XVIII a forma de entendimento desse movimento era diferente. E, apesar do efeito sonoro ser o mesmo, ele era pensado não como uma relação $\mathrm{V} / \mathrm{V}$ dentro do campo harmônico de $\mathrm{C}$, mas como uma nota que indicava uma mudança da natureza escalar (ou propriedade)..$^{15}$

Primeiro vejamos os problemas da gramática musical. Por ela poderemos encaminhar duas posições: (1) a presença de uma tonicização logo nos primeiros compassos da unidade musical; e (2) questões das restrições harmônicas da

\footnotetext{
15 Veja o verbete Signos do Diccionario Musical, de Raphael Coelho Machado (1842). A partir deste ponto usaremos os termos de Coelho Machado. Para as propriedades ficam valendo Natura, Bmolle e Bquadrado. O mesmo para mudança ao invés do termo latino mutanza. Outro elemento importante é a designação de Mi para além do que representa como signo ou corda. Na tradição hexacordal transformar uma nota em $M i$ significava pensala como um sustenido que resolvia num passo "acima"e em $F a$ num bemol que resolvia um passo "abaixo, ou seja, movimento de semitom.
} 
É assim, porque é assim que tem que ser: a retórica galante nos motetes de José Maurício, observada no uso da pedagogia dos partimenti, da gramática das schemata e da oratória musical

época de José Maurício, especificamente sobre a Regra do Mi, que versa, em parcas linhas, sobre o deslocamento das notas "sensíveis".

Como afirmamos logo acima, este trecho realiza uma mudança que acontece a partir da nota Réz do conjunto escalar. Pelas leis hexacordais, a transição entre um hexacórdio Natura para um Bquadrado sempre ocorre sobre a nota Ré, que passa a ser o Lá do hexacórdio Bquadrado. Isso, na prática, não só significava considerar um Bquadrado para a nota Si (na linguagem do solfejo italiano "fazer de $\mathrm{Si}, \mathrm{Mi}$ "), mas, também, uma mudança da propriedade do conjunto escalar, indo de C para G.

No caso desse motete, podemos fazer outras duas observações. Primeiro, a ausência de uma nota Ré na linha do baixo não anulava o raciocínio. Essa é uma questão mais discursiva, já que a mudança da propriedade assumia uma sutileza afetiva dada pela brandura da tonicização escolhida. O outro problema afeta a questão estrutural, já que há uma presença "prematura" de uma nota cromática no baixo, Dó\#. O "lugar" desse evento é importante para determinar se Dó\# seria um Mi ou uma nota já em outro campo tonal.

Duas interpretações seriam possíveis no contexto da mudança. A primeira é que essa nota seria uma terminazione di tono16, ou seja, ela estaria encerrando

16 Heranças provenientes do modelo hexacordal, como a aqui citada, são utilizadas constantemente pelos compositores galantes. Para sintetizar esta ideia, um tom alterado cromaticamente deve necessariamente caminhar para uma nova tonalidade, da qual será o primeiro grau. No caso, o Dó sustenido deve necessariamente caminhar para um Ré, que desta forma se tornará a nova tonalidade. Este é o conceito principal que rege algumas schemata, como a Fonte, que desce, ou a Monte, que sobe. Isso era tão importante que o mestre Giovanni Furno (1817) o apresenta nas primeiras etapas do seu caderno. Porém ele vai além da mutação relacionada ao movimento de semitom, pois discute quatro movimentos: dois por semitom $(\hat{7}-\hat{1}$ e b $\hat{6}-\hat{5})$ e dois por tom $(\hat{4}-\hat{5}$ e $\hat{2}-\hat{1})$. Estes movimentos de baixo serviam para os alunos realizarem as mutações de escala. Além destes movimentos, poderíamos obter mutações por outras etapas como fragmentos da Regra da Oitava, ou realizações diferentes para um determinado baixo. Ademais, devemos sempre ter em mente que "uma mutação de escala enfatiza a chegada em um grau de escala relevante" (Sanguinetti 2012, p. 159). Não obstante, a questão que envolve a mutação de escala, ou tonicização, era muito fluída para um compositor do período. Como ressalta Gjerdingen (2007), o principal ofício do músico era dar ao público dois tipos de sensações diferentes, (1) a sensação de segurança e firmeza e (2) a sensação de estar perdido pelas rápidas passagens para acordes ou tonalidades estranhas. Ou seja, "a estrela principal da música galante não era um acorde da tônica, mas a experiência de um ouvinte, que os mestres dessa arte modulavam com habilidade consumada" (Gjerdingen 2007, p.210). Pensando tecnicamente, a tonicização é um evento local, pois se relaciona a poucos compassos e tem como função colocar os acordes corretos sobre um baixo ao se entender os pequenos fragmentos de baixo para uma determinada passagem, dentro da tonalidade mais adequada (Sanguinetti 2012). Em suma, a 
MUSICA THEORICA Revista da Associação Brasileira de Teoria e Análise Musical 2020, v. 5, n. 2, p. 74-141 - Journal of the Brazilian Society for Music Theory

um tom, logo não seria um Mi. Essa seria uma operação simples em termos sonoros, mas complexa em termos de gramática, exigindo uma transposição de todo o sistema um tom acima considerando a lógica do solfejo. Outra perspectiva - a plausível - é considerar essa nota uma ucita di tono, ou seja, uma nota "fora" da relação diatônica do hexacórdio 4, que faria uma relação "eventual" de Mi. E isso é importante, pois na Regra da Oitava tradicional qualquer acorde cuja natureza fosse o V grau deveria ser escrito sobre a fundamental, ou seja ${ }_{3}^{5}$ ou 7 . No entanto, dentro dos usos de compositores galantes de meados do século XVIII, prevalecia a chamada Regra do Mi. Esta determinava que todo $\mathrm{Mi}$, principalmente em tempo fraco, deveria ser um acorde 6 (Gjerdingen 2007, p. 33), e não ${ }_{3}^{5}$. Como vemos, José Maurício segue essa regra desenhando sua progressão de baixo saltando da nota Mi para Dó\#, e sobre ele escreve um acorde ${ }_{5}^{6}$, acompanhando as tendências de sua época (Fig. 8, c. 4). Logo, estamos na presença de uma ucita di tono.

O que justifica todo esse exercício, em termos de análise? Primeiro, a restrição da harmonização. Determinar a posição correta do $M i$, ou seja, a nota sustenido, não só é determinante para compreendermos o tipo de acorde a ser usado, como afeta outros parâmetros. A posição do $M i$ entre outros determina a propriedade que, consequentemente, era parte de um sistema maior. Logo, estamos falando diretamente de problemas da relação tonalidade-afeto. Em outras palavras, uma tonicização para G, que se inicia quatro compassos após um início em C é um movimento expressivo, mesmo que as propriedades dos dois conjuntos hexacordais sejam próximas. ${ }^{17}$

Aqui ainda cabe dizer que o que regia estas sutilezas, como um processo expressivo, era, primeiro, um paradigma que considerava que uma estrutura musical poderia se mover por conjuntos escalares diferentes, os hexacórdios,

ideia de tonalidade de uma forma mais ampla como entendemos hoje, não era compartilhada de forma tão abrangente no período galante, pois em muitas ocasiões a discussão era mais local do que global.

${ }^{17}$ A adaptação modernizante do sistema guidoniano (solfejo italiano), que ficou conhecida como solfejo francês, desconsiderou as duas propriedades (Natura e Bquadrado) como distintas. Essa fusão foi determinada pelo fato dos hexacórdios Natura e Bquadrado compartilharem a relação de distância do tetracórdio inicial (T-S-T); em termos de solfeggio, podemos dizer que $\hat{2}-\hat{3}-\widehat{4}$ em C tem a mesma relação intervalar do que $\hat{2}-\hat{3}-\hat{4}$, em G. No entanto, cremos que algumas questões não se dissiparam em termos práticos, somente se tornaram questões de discussões doutrinárias, inclusive pela natureza harmônicas diferentes ods dois semitons envolvido, mi-fa, si-dó. 

motetes de José Maurício, observada no uso da pedagogia dos partimenti, da gramática das schemata e da oratória musical

dentro de uma mesma tonalidade. E que cada conjunto tinha uma natureza afetiva diferente. Assim, considerando que o compositor galante era ciente de estratégias oratoriais, mesmo as pequenas nuances eram tratadas a partir de crença na capacidade do reconhecimento auditivo, ou seja, um agenciamento das estratégias do compositor. Logo, termos uma mudança no quarto compasso "provocando" uma sutil oposição entre duas naturezas escalares distintas (uma Natura e outra Bquadrado) indica e indexa questões que o compositor considera importantes no trato discursivo da obra.

Outrossim, podemos justificar esses movimentos em tão curto espaço de tempo como cumprimento de uma das regras de ouro da Oratória. Esta regia que os primeiros momentos do enunciado eram fundamentais para prender a atenção do ouvinte. Desta forma, este trecho, em termos de estratégia musical cumpre o que dele se esperava: a exposição dos argumentos (tonalidade, temas, gestualidades etc.) que seriam trabalhados no decorrer da obra. Vale recordar que José Maurício escreve uma seção que no terceiro compasso cria uma quebra diatônica, no entanto inicia uma tonicização, branda, entre C Natura e G Bquadrado. Por ser o início da obra, o que chama mais atenção não é a mudança da propriedade, mas sim a forma, com a presença de um Mi como ucita di tono. Esta nota parece nos dizer que devemos nos atentar à rápida tonicização. E sim, no decorrer do motete, e mais, no conjunto dos motetes da Semana Santa, mais do que um hexacórdio Bquadrado, a nota Sol, que rege esse hexacórdio, aparece em muitos momentos carregada de simbolismo. Ela é a nota, ou harmonia, que, escrita sobre métricas associadas à morte, nos trazem metáforas sobre a transfiguração, ou seja, um destino que leva a questões fora da ordem natural da vida humana.

\section{Das escolhas cadenciais}

Continuando exemplificando a composição numa perspectiva da mentalidade possível, passemos para o problema das cadências, depois de apresentarmos algumas questões das regras de contraponto e do sistema harmônico através da modelagem hexacordal. Aqui, continuando a discussão sobre os motetes de José Maurício, destacaremos um pequeno detalhe que se desdobra do jogo harmônico, e que nos servirá de guia para o trabalho de argumentação discursiva que afirmamos ser sempre a intenção de qualquer 
MUSICA THEORICA Revista da Associação Brasileira de Teoria e Análise Musical 2020, v. 5, n. 2, p. 74-141 - Journal of the Brazilian Society for Music Theory and Analysis @ TeMA 2020 - ISSN 2525-5541

compositor galante: material que está numa dimensão gramatical mas que, mais que uma função sintática, colabora com questões semânticas. Neste espaço trataremos das cadências.

Vejamos isso voltando ao peroratio (c. 40-42) do motete Improperium expectavi cor meum (Fig. 9). Nestes dois compassos, chama a atenção um movimento cadencial que, de partida, afirmamos ser singelo no atestado da perícia de José Maurício como mestre de capela que consubstancia essa ideia de objetivação comunicativa. Isso porque nesse trecho há uma cláusula que abre a possibilidade de um debate não só sobre as tipologias desses esquemas em relação às suas funções, mas, também, sobre as relações intra e extramusicais.

Começando pela função, a clausula que escreve José Maurício "estaria" próxima, na tradição dos tratados germanófilos, a uma clausula formalis perfectissima (Gjerdingen 2007, p. 135) que, aliás, era consideravelmente comum na música galante. ${ }^{18}$ "Estaria" porque, apesar das vozes manterem o esquema

18 Praticamente todos os tratados de contraponto discutem as propriedades e hierarquias dos movimentos contrapontísticos de conclusão. Desde o século XVI, os tratados descrevem como clausulae os movimentos de acerto das vozes para o encerramento de uma seção ou mesmo o final da obra. Já no século XVIII, principalmente no universo germânico, o conceito clausula passou a ser sinônimo de cadência. No entanto, alguns ainda definiam clausula como o movimento das vozes sobre a cadência do baixo. Na Arte Explicativa do Contraponto, um texto atribuído a André da Silva Gomes, mas que na verdade era um pastiche de muitos autores (de Pietro Cerone a Manuel de Moraes Pedroso), na Lição 14 o texto diz: "clausula ou cadência é o fim ou terminação de uma frase ou período sonoro e harmônico ou terminação, fim ou remate de qualquer obra de música ou em cada uma de suas partes ou do seu todo" (Duprat 1998, p. 168). As denominações também variavam. No universo germanófilo o termo formalis perfectissima designava, principalmente, uma clausula cujo movimento do baixo era (5)-(1). Já no ambiente lusófono, esse movimento era, desde o século XVI, denominado como Cadencia Vera V-I (Cadencia Vera por si só designava, assim como no universo germanófilo, o movimento característico do baixo como (2)(1) ou Cadencia Verdadeira, e, dependendo do movimento das vozes, concluindo o cantus no VIII grau, Cadencia Perfeita. Novamente recorremos a André da Silva Gomes para pacificar o termo numa prática comum a José Maurício Nunes Garcia: "as cláusulas, segundo as suas qualidades sonoras, dividem-se em cláusulas perfeitas e cláusulas imperfeitas. As perfeitas, a que também chamam cláusulas verdadeiras, são as que terminam na 8a , e as imperfeitas, a que também chamam fingidas, são as que terminam na $3^{\underline{a}}$ ou $5^{\text {a }}$ ou $6^{a}$ corda do tom" (Duprat 1998, p. 169).

Cabe ainda ressaltar que em seu estudo sobre as schemata, Robert Gjerdingen observou que, apesar de as cláusulas continuarem vigentes, elas podiam "absorver" alguns elementos característicos dos esquemas de contraponto. Em outras palavras, poderíamos ter uma clausula finalis perfectissima que poderia fazer um movimento no cantus que remetessem a movimentos de esquemas Do-Re-Mi; Do-Si-Do ou Cudworth. Isso porque, a manutenção do movimento do baixo era o que determinava a qualidade da clausula, e ao mesmo tempo possibilitava várias resoluções no cantus, como vimos pelos compilados de André da Silva Gomes. 
É assim, porque é assim que tem que ser: a retórica galante nos motetes de José Maurício, observada no uso da pedagogia dos partimenti, da gramática das schemata e da oratória musical

(5) (1), o "subir o meio tom" está no alto. José Maurício escreveu no cantus o movimento 2-3, o que deveras diminui a força do esquema numa perspectiva de perfectissima.

Esta disposição das vozes se torna interessante ao nos depararmos com o estudo de Luísa Castilho (2009) sobre a obra do compositor português radicado como mestre de capela em Múrcia, Manuel de Tavares (c. 1585-1638). Trabalhando com tratados de autores ibéricos, como o do espanhol Frei Thomas de Sancta Maria (Libro llamado Arte de tañer fantasia, Valladolid, 1585) e do português Manuel Nunes da Silva (Arte Minima, Lisboa, 1685), Castilho nos dá a possibilidade de vermos que o movimento das vozes nessa cadência está de acordo com o que se reconhecia no universo ibérico como clausula vera incompleta invertida (Castilho 2009, p. 175). ${ }^{19}$ Assim, o "que não estava no lugar" no motete analisado para uma clausula formalis perfectissima seria na verdade uma condução que remetia a uma sonoridade antiga, inclusive pela suspensão de $4^{\mathrm{a}}$.

Isso nos leva para outras relações além da questão gramatical, já que a tipologia desta clausula assume um caráter de significante, ou seja, cria um sentido de escuta além de sua função. Primeiro, como o próprio Gjerdingen (2007, p. 46) afirma, a presença de clausulæ vera nos compositores do século XVIII trazia à obra uma referência de estilo antigo. Logo, além deste forte lastro, que consideramos na tradição polifônica ibérica, este motete reforça a estrita observância do estilo eclesiástico usado por José Maurício também pelo estilo pieno na textura (estilo natural de momentos penitenciais) e o pictorialismo (e não o jogo dos estilos tópicos) como ferramenta semântica. Em síntese, há uma coerência estilística na escrita desta unidade musical.

O que justificaria isso? Duas teses são plausíveis. A primeira seria mais pacificada: José Maurício, como músico de uma corte tradicionalista na observância do catolicismo, tinha como perícia um decoro que, possivelmente,

19 Esta se denomina incompleta invertida segundo a autora por dois motivos: (1) a cláusula tenorizans $(\hat{2}-\hat{1})$ deve ser posta sempre em uma voz mais grave que a cláusula cantizans $(\hat{7}-\hat{1})$. No exemplo, ocorre o oposto, a tenorizans está na voz mais aguda, por isso recebe o termo clausula vera invertida. (2) O termo incompleta se refere ao fato da tenorizans caminhar para o $\hat{3}$ (Mi) em detrimento do 1 (Dó), que proporcionaria o movimento completo. Gjerdingen (2007) a classifica como cláusula perfectíssima, pois julga as cadências pelas vozes exteriores, sendo o movimento $\hat{5}-\hat{1}$ no baixo a justificava para a utilização deste termo. Ademais, para o autor, a cláusula vera é uma das variantes proveniente do que ele classifica como cadência tenorizan, classificada pelo baixo 2 -1̂. Para a cláusula vera é necessário a voz soprano em 7 -1̂. 
MUSICA THEORICA Revista da Associação Brasileira de Teoria e Análise Musical 2020, v. 5, n. 2, p. 74-141 - Journal of the Brazilian Society for Music Theory and Analysis @ TeMA 2020 - ISSN 2525-5541

era marcado pela manutenção de modelos ancestrais de religiosidade, logo, de sonoridades recorrentes a este estado. Isso justificaria todas as escolhas expressivas e gramaticais da música, inclusive uma clausula típica da polifonia ibérica dos séculos XVI e XVII, considerando o gênero motete. Tese que se fortalece na medida que sabemos, hoje, que obras de compositores como Manuel Cardoso (1566-1650) ainda eram copiadas no território brasileiro, na segunda metade do século XVIII.

Outra tese está ancorada no plano musical da missa cantada e nos remete a questões semânticas. Inclusive considerando que haveria outras possibilidades de conclusão, e que eram do domínio do compositor. José Maurício, por exemplo, poderia escrever uma cadência, digamos, mais moderna, como uma Prinner. E a condução das vozes não custaria grande exercício, isso porque as funções harmônicas seriam as mesmas, bastando ajustar as vozes a um movimento descente no cantus iniciando na nota Lá até o Mi, ou seja, até o $\widehat{3}$. Ora, usando esta fórmula conseguiria uma sonoridade bastante próxima do que conseguiu com a clausula vera imperfeita invertida. Logo, supomos que a questão não era gramatical, mas de significação. E, pela lógica galante, alguns elementos musicais estariam conectados a essa escolha, indexando-a num passado ou projetando-a a um devir. E neste ponto é preciso ampliar a perspectiva do motete analisado.

O Improperium expectavi cor meum é o texto do Offertorio da missa de Domingos de Ramos, escrito no oitavo modo (com finalis em Dó). Segue a esse offertorio uma breve leitura - Concéde, quaésumus Dómine [...] - com sua respectiva doxologia (Officium Majoris Hebdomadae..., 1923, p. 81). Esta doxologia evidentemente continua no tonus de Dó, que é o tonus de toda a missa. Porém, neste trecho específico, a recitação inicia com a nota Mi (Fig. 9). Devemos levar em conta, também, que a música polifônica "harmonizava" com a recitação da missa. Logo, podemos supor que José Maurício tratava de "acomodar" a cantoria com a clausula. Provavelmente mais que isso. Tratava de criar um enlace, expressivo, para uma recitação que rompia com a corda preponderante da recitação. Isso justificaria a imperfeição invertida da clausula vera $V$-I, ou seja, fazer soar o Mi no cantus para orientar uma retomada sem sobressaltos, considerando que o salto de sexta era considerado áspero. Desta forma, e considerando a natureza da mentalidade galante, devemos analisar as possibilidades por uma expectativa dramática de amplo alcance, no caso dentro da Liturgia da Semana Santa. 


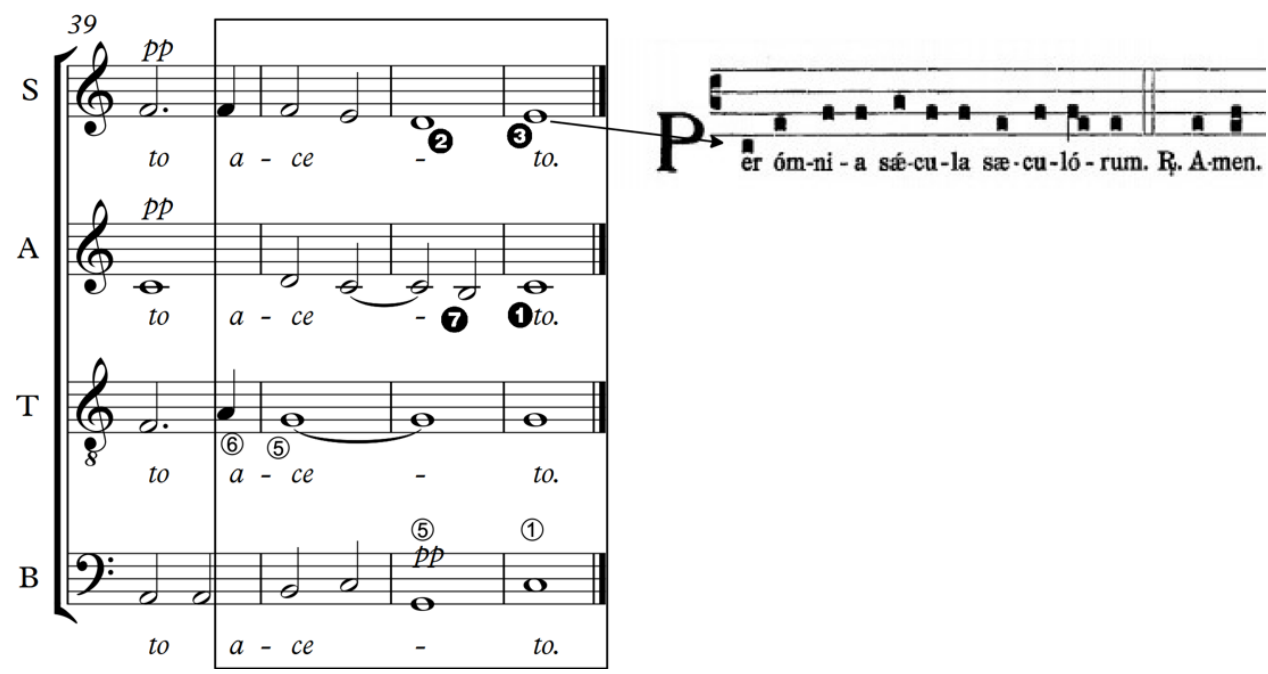

Figura 9: Suposto movimento de enlace entre o fim do motete polifônico do offertorio com o cantochão do communion da missa de Domingo de Ramos, no motete Improperium expectavi cor meum.

Primeiro ponto, o estilo. Este motete desde o início traz uma marca indelével de estilo penitencial que não só culmina como se projeta na clausula analisada. É uma questão que se desdobra em muitas, mas primeiro no decoro, pois cumpre uma expectativa local cumprida com sonoridades tradicionais do motete ibérico.

Segundo ponto, o projeto expressivo. Como poderemos ver, esta clausula cumpre um papel indexado pelo contexto litúrgico. Qual contexto? A transição afetiva que ocorre em Cristo e que está no subjetivo do próprio texto do motete. Quem prova isso é o tonus da missa cantada, que, mesmo continuando na corda de Dó, depois da reflexão sobre os impropérios, retoma a recitação começando pela nota $\mathrm{Mi}$. E essa sutileza, que está na quebra da sonoridade geral da missa, foi indexada no início dessa unidade musical, como mostraremos abaixo.

Em conclusão para este trecho, na mentalidade do compositor galante todo elemento participa do processo expressivo, inclusive em pequenos detalhes. Aqui vimos como uma simples cadência "carrega" inúmeras função, inclusive "marcar" a sonoridade para servir de gatilho com uma identidade sonora específica, no caso uma referência ao estilo antigo tradicional da música religiosa ibérica. 
MUSICA THEORICA Revista da Associação Brasileira de Teoria e Análise Musical 2020, v. 5, n. 2, p. 74-141 - Journal of the Brazilian Society for Music Theory and Analysis@ TeMA 2020 - ISSN 2525-5541

\section{Das Schemata}

A questão da clausula nos leva diretamente às questões das schemata, inclusive porque a clausula é, para a gramática galante, uma schemata. Mais que isso, ela pode ser, como vimos, um significante expressivo que tem potencial de detonar várias conotações de sentido. Assim, depois de vermos sobre as questões dos partimenti, as escolhas tonais e a construção harmônica, e inclusive como uma estrutura cadencial participa de um projeto expressivo em termos de retórica, nos cabe ver qual o papel das schemata.

Primeiro, devemos sublinhar que as schemata, num sentido lato, cumprem papel sintático. No entanto, é possível vermos usos semânticos, inclusive como tópicas. Estudos recentes mostram que algumas schemata, como as romanescas e a le-sol-fi-sol, entre outras, podem ser consideradas campos expressivos para uma estética tópica, ${ }^{20}$ assim como para dar suporte na construção de pictorialismos harmônicos. Este é o caso do trecho que ora analisamos de José Maurício Nunes Garcia. Porém com algumas adaptações que ajustam as schemata ao projeto expressivo.

Nos mesmos compassos iniciais que vimos trabalhando, José Maurício articula duas schemata que Joseph Riepel, em seu tratado Anfangsgründe zur musicalischen Setzkunst (1⿳⺈ ed. em 1752), denominava Fonte e Ponte (Fig. 10). ${ }^{21}$ No

${ }^{20}$ Estudos de schemata como estruturas tópicas têm sido publicados com maior frequência. Destacamos aqui os trabalhos de Vasili Byros, Topics and Harmonic Schemata: A Case from Beethoven (2014), e Olga Sánchez-Kisielewska, Interactions between Topics and Schemata: The Case of the Sacred Romanesca (2016). No Brasil, alguns estudos avançam no mesmo sentido, como o de Ágata Yozhiyoka Almeida e Diósnio Machado Neto, Interação entre tópicas musicais e o esquema harmônico le-sol-fi-sol na Missa de Réquiem (1816) de Marcos Portugal (2021).

${ }^{21}$ No acervo de lições dos mestres da música galante, o aluno era submetido a exercícios para articular a forma em diversas situações. Para aberturas, aprendia a lidar com as romanescas, muitas vezes associadas às prinners (esse nome foi dado em homenagem ao mestre que ensinava esse tipo de progressão, Johann Jacob Prinner). Para fechamentos, a quiescenza (termo que remete à suspensão do movimento). Para a transição de seções, Joseph Riepel (1709-1782) ensinava três progressões, por ele denominadas Fonte, Monte e Ponte. Estas denominações eram, como a quiescenza, metáforas. A razão de seus nomes era devido às sequências melódicas que elas promoviam. Todas se constituíam de duas partes, mas a Fonte articulava uma sequência através de passo melódico de um tom entre duas frases; a Monte fazia as frases "subirem" um tom; e a Ponte mantinha um pedal sobre a dominante, ou seja, um movimento linear sustentado sobre uma nota (Gjerdingen 2007, p. 197; ibidem, nota 1, cap. 14, p. 491). No fundo, eram variantes de

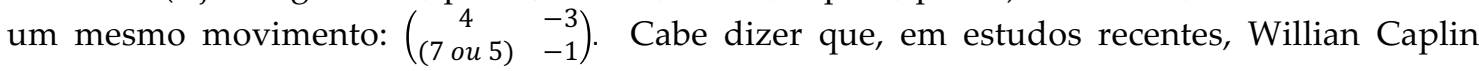
(Neuwirth 2015, p. 21) associa os esquemas de contraponto a qualidades das progressões 
É assim, porque é assim que tem que ser: a retórica galante nos motetes de José Maurício, observada no uso da pedagogia dos partimenti, da gramática das schemata e da oratória musical

entanto, não o faz de forma escolar, e sim "adapta" ambos os esquemas, inclusive agindo sobre uma de suas sonoridades capitais.

Vejamos, na Fonte aprendida de forma escolar o movimento contrapontístico 4-3 do cantus deveria ser antecedido por um movimento 65, na mesma voz. Mesmo quando o compositor optava por "comprimir" esse esquema em dois acordes, e não sobre duas semi-frases, que eram separadas por um tom no sentido descendente, o movimento 6-5 deveria estar em "alguma" das vozes. José Maurício observa isso, mas com uma sutileza: a nota Lá que resolve em Sol não forma mais o acorde de Lá maior, mas o de Ré menor (c. 5, Fig. 10). Desta forma o movimento está, digamos, defasado. Isto não afeta o esquema porque o movimento (4-3 no alto tem bastante saliência, mas lhe dá uma função expressiva específica, justificada nas suas estratégias oratoriais fundadas sobre um espaço de ambiguidades.

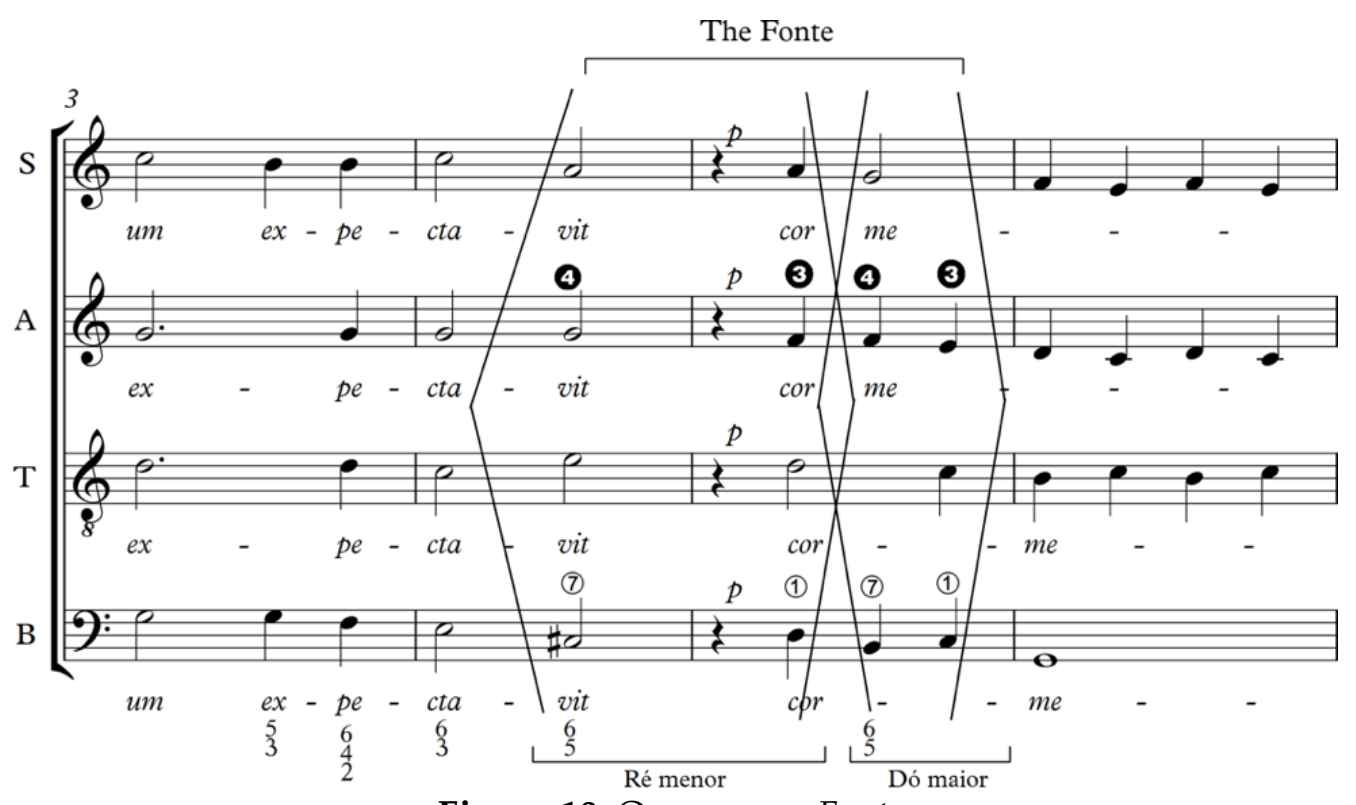

Figura 10: $\mathrm{O}$ esquema Fonte.

O que isso indica? Que a questão da oratória prevalecia, também, sobre o uso ortodoxo das estruturas esquemáticas, a ponto de afirmarmos que a perícia do compositor saberia manejar com as fronteiras da inteligibilidade dos elementos retóricos; como vimos afirmando durante todo este texto. Sobre esses limites, ou seja, as sonoridades características dos movimentos contrapontísticos, é que os compositores alteravam ou ocultavam notas. Por outras palavras, os

harmônicas. Assim, os classifica como os de prolongação (a Ponte seria para prolongação da dominante); os de sequência (como a Fonte e a Monte); e os de cadência (como a Prinner). 
esquemas de contraponto eram usados em prol do discurso. Desta forma, estressavam a inteligibilidade, às vezes no extremo de sua presença, em benefício do argumento; aliás esse estresse da retórica era uma das estratégias usadas por Beethoven em sua poética. José Maurício, mesmo longe de ser tão radical como Beethoven com os pressupostos dos esquemas, não fugia à regra de sua época. Neste caso, devemos analisar o que justifica a pequena alteração do esquema que sublinhamos acima. Novamente partimos do geral para o particular, observando que, novamente, é a questão da relação música-texto.

E é justamente essa relação que nos permite olhar mais detalhes, além das escolhas sobre tonicização e esquemas. Vejamos agora como esses recursos se articulam com as figuras de retórica.

Voltemos à análise do trecho inicial do motete Improperium expectavit cor meum (Fig. 11). A progressão harmônica com a qual a música inicia nos remete às variantes de contrapontos para transição, no caso o esquema que Riepel ensinava sob o nome de Ponte. Esse esquema se justificaria considerando duas "consequências". Primeira, que esse esquema possibilita trabalhar um campo harmônico a partir de uma ambiguidade, como mostra Gjerdingen (2007, p. 198), analisando um exemplo do próprio Riepel. Explicamos. A Ponte, em sua versão escolar, é escrita sobre um pedal com (5), associada ao (2) no cantus, quando muito um 4; ou seja, é um esquema de prolongação da dominante. No entanto, neste trecho, essa configuração não se dá de forma explícita. Aliás, muito pelo contrário. A nota que forma um pedal nos compassos 1 e 2 é a nota fundamental da tônica, ou seja, Dó; mais que isso, o acorde de Dó ${ }_{3}^{5}$.

Escolarmente, essa passagem não se configuraria como uma Ponte, no que diz respeito à prolongação da dominante. Porém, José Maurício, ao escrever sobre esse pedal na fundamental de $C$, também escreve uma circulatio, cujas notas pivôs são Ré (tenor) e Fá (alto). Num andamento moderato para adagio, como pede o decoro do texto, a harmonia dessa circulatio causa mais do que uma apoggiatura sobre um acorde ${ }_{3}^{5}$, promove a escuta de um acorde de dominante sobre um pedal de tônica, ou seja, o trecho se forma, também, por uma "saliência" num acorde ${ }_{2}^{4}$. Este movimento harmônico cria uma ambiguidade entre as sonoridades de Dó maior e Sol maior. E mais que isso, o terceiro compasso desse trecho é um acorde de G que resolve em um acorde em $\hat{6}$, por um movimento (4)-(3) no baixo (c. 3). Ou seja, a dominante está em prolongação, mesmo que velada. 


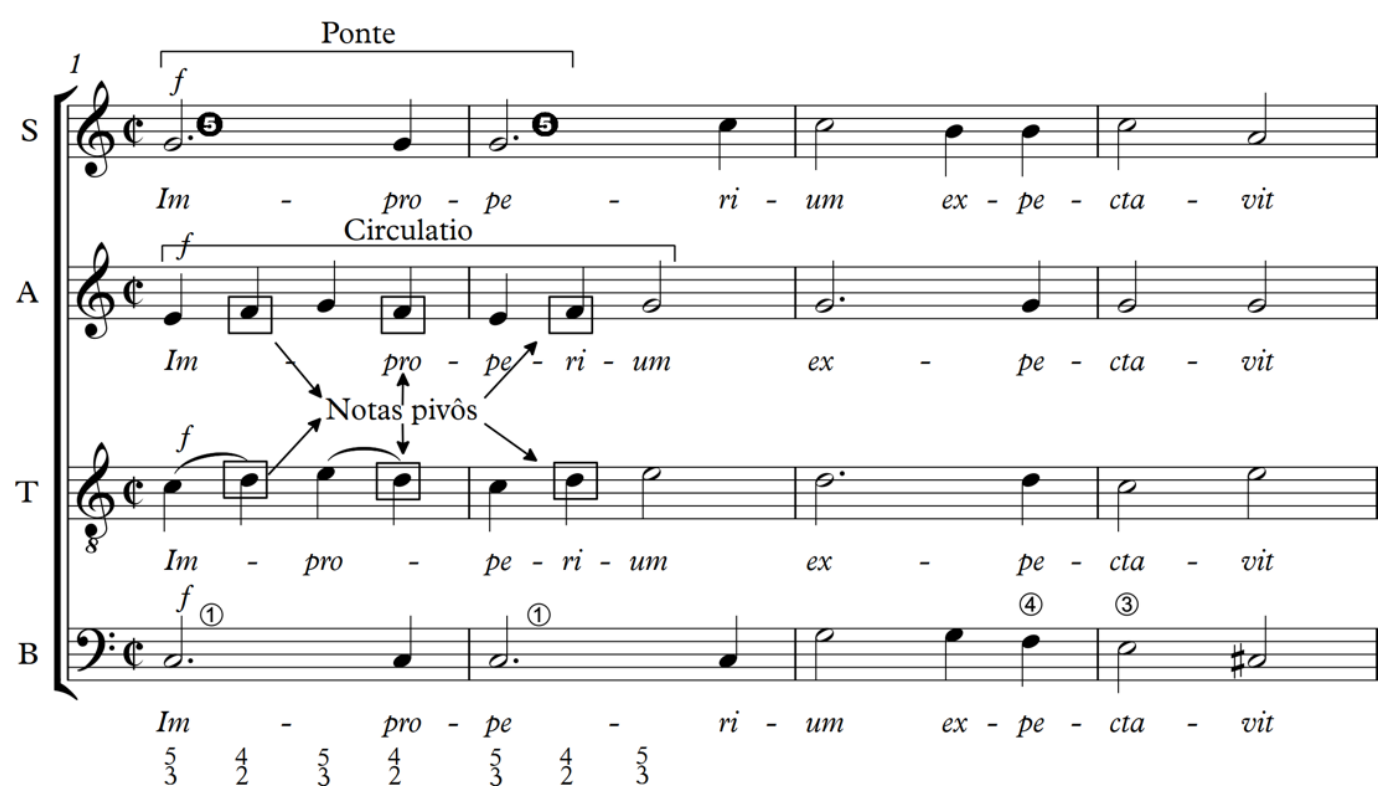

Figura 11: O esquema Ponte nos compassos 1 2.

Outra consequência do uso desse esquema nos leva para a sequência do trecho que, como veremos, articula uma questão discursiva. Recordando, na cabeça do compasso 4 temos um axde emb̂ sobre C, alcançado por uma Ponte. A música, também como vimos, está no início da mudança - tonicização de $\mathrm{C}$ para G (o oitavo modo, como plagal, traz em si o tetracórdio descendente $C-G$ ). No projeto discursivo, José Maurício sublinha essa mudança com uma ucita di tono seguida de uma aposiopesis, ou seja, uma figura retórica de intensificação usando o silêncio.

Em outras palavras, José Maurício marca todo o ambiente por elementos típicos para trechos disfóricos (é, sobretudo, um fator de indexação). Não bastasse isso, escreve um esquema de transição (por sequenciação) caracterizado pelo movimento descendente, a Fonte. Esta se realiza após o acorde ${ }_{5}^{6}$ sobre Dó\# e segue escolarmente os movimentos contrapontísticos: 6-5; o $4-\hat{3}$ no alto, e o (7)-(1). Ademais, a "queda" do acorde de Ré menor para o de Dó maior, em 6, é rápida, em meio a um movimento que aumenta essa expectativa por vários movimentos sobrepostos, a começar pela omissão do movimento 6-5 dentro do esquema Fonte (Fig. 10, c. 5), como já expusemos acima. Falta dizer que essa “omissão" diminui a tensão, pois o 6 se torna 5 na saída da aposiopesis, e, mais, impulsiona o contraste pelo fluxo rítmico (contraponto em "diminuição") até chegar a corda G. E não há que esquecer... o movimento se inicia, no baixo, na 
MUSICA THEORICA Revista da Associação Brasileira de Teoria e Análise Musical 2020, v. 5, n. 2, p. 74-141 - Journal of the Brazilian Society for Music Theory

nota Dó\#, ou seja, há uma quarta aumentada entre o início da progressão e sua finalização. Por fim, após a Fonte, José Maurício retoma o esquema Ponte (Fig. 12, c. 6 e 7), antes de seguir para a cadência simples que encerra este denso trecho.

Indo para um quadro geral (Fig. 12), o trecho inicia com uma Ponte, marcada sobre uma métrica em dáctilo (que trataremos adiante), seguida de uma Fonte, marcada por dois recursos retóricos de intensificação, articulando-os: uma figura de silencio, a aposiopesis, seguida de uma aceleração do fluxo rítmico, por dois movimentos oblíquos de semitom. Retoma o esquema da Ponte, para encerrar com uma cadência simples.
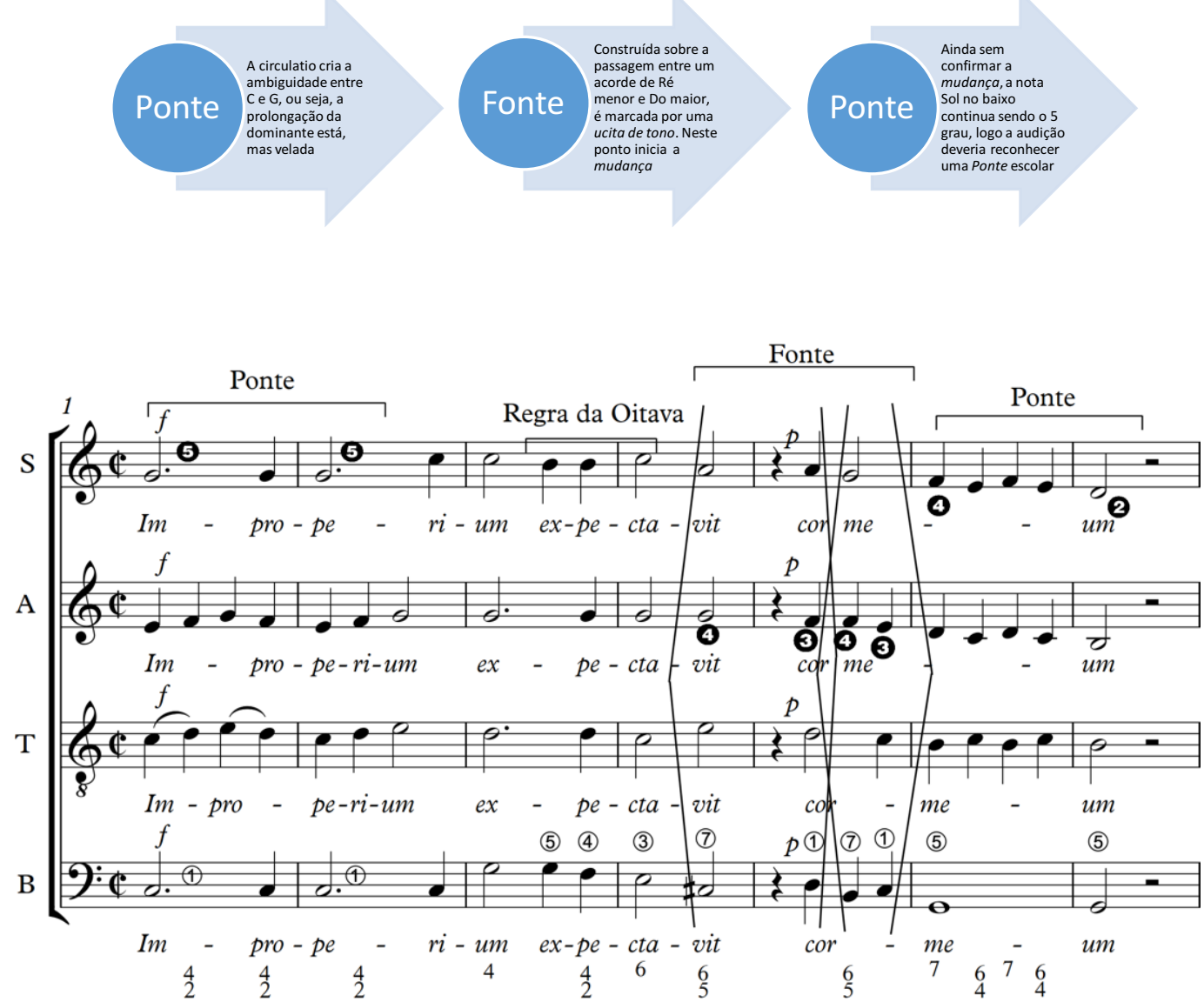

Figura 12: Análise dos compassos 1 7.

Por fim, reiteramos que assim como os outros parâmetros já analisados, as schemata corroboram que a tese de um pictorialismo sobre um destino, trágico, a partir deste ponto se intensifica. No entanto, é o início, também, do plano do sacrifício salvífico. Falta dizer, como síntese, que, no que se refere aos esquemas, José Maurício usa dois esquemas de transição articulados. Como metaforiza isso? Com recursos combinados, inclusive dos esquemas. Ora, se a Ponte desenha uma 

motetes de José Maurício, observada no uso da pedagogia dos partimenti, da gramática das schemata e da oratória musical

passagem linear, como prolongação de um movimento instável entre tônica e dominante, a Fonte representa a descida. Descida também realizada pela tonicização, e confirmada pela Ponte do c. 6 e 7, agora declaradamente na dominante.

Resta dizer que, a partir de um movimento tonal que parte da corda $\mathrm{C}$, e através de uma ucita di tono no Dó\# (uscita di tono de Ré) chega à corda G, no c. 9, é marcada pelo movimento da instabilidade. Primeiro porque se chega a $G$ por uma rápida sucessão entre acordes ${ }_{3}^{5} \mathrm{e}_{4}^{6}$ sobre um pedal no $\hat{5}$ (nota Sol) seguido de uma nova aposiopesis (Fig. 13). Segundo porque a "chegada" é "falsa", pois na verdade ela é um "imbricamento", pois, o que deveria ser o ponto final da tonicização, é imediatamente desestabilizado por um cromatismo ascendente. Enfim, é a pictorialidade da ascensão, marcada pela palavra que nesse parágrafo se repete: a instabilidade.

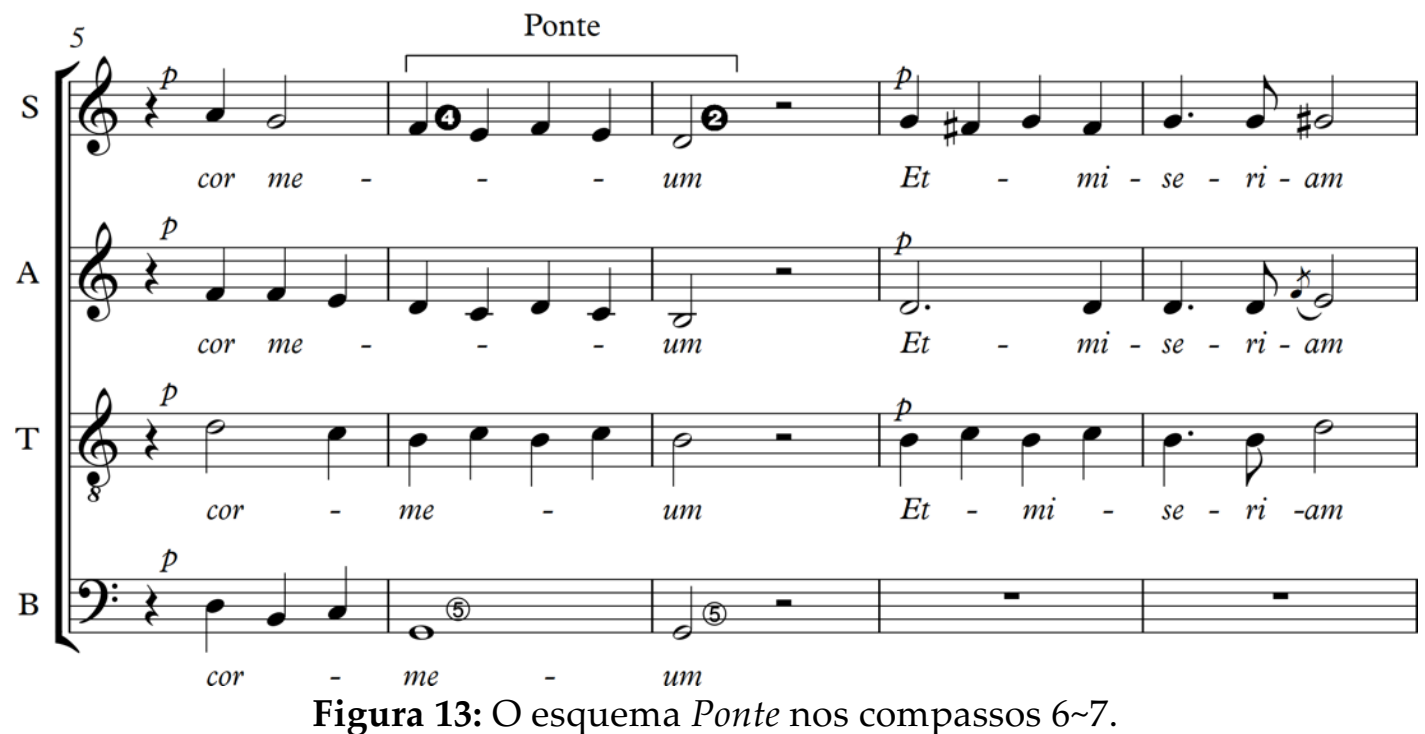

Em termos oratoriais, José Maurício nos induz a um caminho de "confirmação" das dúvidas. A primeira Ponte estabelece a dúvida, ou seja, os dois primeiros compassos funcionariam como "refutação", por isso a ambiguidade entre C e G. A Fonte intensifica esse conflito, mas o leva ao hexacórdio de G (o que ainda não é a tonalidade de Sol, detalhe a ser considerado como importante). Neste ponto, através de uma segunda Ponte, a confirmação de um destino se estabelece (por isso ainda é um esquema de transição), e impulsiona a instabilidade para a seção central do motete.

A seguir, veremos que a métrica ajuda nesse discurso sobre as instabilidades, para não dizer ambiguidades. 
MUSICA THEORICA Revista da Associação Brasileira de Teoria e Análise Musical 2020, v. 5, n. 2, p. 74-141 - Journal of the Brazilian Society for Music Theory and Analysis@ TeMA 2020 - ISSN 2525-5541

\section{Das escolhas métricas}

O último elemento retórico que trataremos é, possivelmente, o mais complexo para entendermos a sua presença a partir de uma escuta contemporânea. Como introdução, devemos dizer que a métrica, desde muito, deixou de ser um aspecto entendido enquanto valor significante para uma análise discursiva da música. No entanto, como observa Danuta Mirka, através de Mattheson, a métrica era um dos parâmetros afetivos dos mais importantes para a estética galante.

Se, inicialmente, Mattheson se concentra nas qualidades afetivas dos intervalos, é porque elas foram discutidas por Kircher e Christoph Raupach, aliás Veritophilus, em um tratado sobre o poder afetivo da música que Mattheson editou e prefaciou (1717), mas sua discussão posterior na Parte Dois de Der vollkommene Capellmeister deixa claro que todos os parâmetros musicais têm qualidades afetivas. O mais importante entre eles é o ritmo (grifo nosso). Mattheson demonstra isso em um experimento no qual ele transforma afetos de melodias mudando seus padrões rítmicos. Como resultado, ele transforma cinco corais em danças - um minueto, uma gavota, uma sarabande, uma bourrée e duas polonaises-e duas danças-um minueto e uma angloise-em corais. Em cada caso, a mudança do padrão rítmico causa uma mudança de metro. As qualidades afetivas da métrica não são discutidas em Der vollkommene Capellmeister, mas Mattheson remete o leitor a seu primeiro tratado, Das Neu-Eröffnete Orchester, onde as métricas são atribuídas a diferentes afetos e relacionadas a diferentes gêneros. (Mirka 2014, p. 11).22

Por sua vez, Willian Caplin explica que, desde o início do século XVIII até o seu último quartel, a questão métrica passou por uma profunda modificação enquanto paradigmas teóricos. Paulatinamente, a taxonomização dos acentos métricos em padrões reconhecíveis foi, digamos, mitigado por uma compreensão

\footnotetext{
22 "If, initially, Mattheson concentrates on affective qualities of intervals, this is because they were discussed by Kircher and Christoph Raupach alias Veritophilus in a treatise about affective power of music that Mattheson edited and prefaced (1717), but his further discussion in Part Two of Der vollkommene Capellmeister makes clear that all musical parameters have affective qualities. Paramount among them is rhythm. Mattheson demonstrates this in an experiment in which he transforms affects of melodies by changing their rhythmic patterns. As a result, he turns five chorales into dances - a minuet, a gavotte, a sarabande, a bourrée, and two polonaises - and two dances - a minuet and an angloise-into chorales. In each case the change of rhythmic pattern causes a change of meter. Affective qualities of meter are not discussed in Der vollkommene Capellmeister, but Mattheson refers the reader back to his first treatise, Das Neu-Eröffnete Orchestre, where meters are assigned different affects and related to different genres." (tradução nossa).
} 
É assim, porque é assim que tem que ser: a retórica galante nos motetes de José Maurício, observada no uso da pedagogia dos partimenti, da gramática das schemata e da oratória musical

mais autônoma do trabalho rítmico. No entanto, a partir da segunda metade do século XVIII, novos paradigmas ampliaram os limites dos acentos padronizados das métricas adaptadas do modelo da literatura grega:

[...] os acentos oratórios e expressivos (sendo este último uma versão mais forte e enfática do primeiro) ocorrem independentemente da métrica: são tons individuais (ou grupos de tons) especialmente enfatizado tanto na composição (por meio de figuras musicais, harmonias ou dissonâncias) e na performance (por meio de intensificação dinâmica) (Caplin 2008, p. 670).

Por outras palavras, a vigência dos padrões métricos discutidos desde o século XVII, e organizados numa teoria como o da rhythmopoeia, incorporaram, na segunda metade do século XVIII, concepções de alargamento das regras rítmicas que deram novo alento a capacidade expressiva da música. ${ }^{23}$ Enquanto as formas métricas já estavam compreendidas, e se articulavam como um princípio para as teorias dos afetos (Affektenlehre), cada vez mais adjetivos qualificantes que indicavam o andamento e o caráter no início dos movimentos eram utilizados em meados para frente do século XVIII (Allanbrook 1983, p. 14). Isso não quer dizer que os modelos métricos foram superados, no entanto, não se censurava a quebra da inteligibilidade dos padrões antigos.

Como demonstra Cooper \& Meyer (1960), compositores galantes passaram a usar construções métricas compostas, a tal ponto que o rigor delas era mitigada num processo complexo de "camadas" de pulsações. Isso se deu por uma simples constatação, o ritmo, antes tratado como unidades da métrica, não seriam eles mesmos a própria métrica (Cooper; Meyer 1960, p. 7). Assim, a articulação dos modelos rítmicos passou a ser relacionada aos modelos prosódicos e, uma vez independentes da métrica, puderam ser estruturados para além da enquadração métrica. Uma das consequências dessa postura galante diante do ritmo foi que passaram a ser melhor articulados em um âmbito macro da arquitetura da obra.

Este é o caso da escrita deste parâmetro no motete de José Maurício. Como fator de seu tempo, o jogo de acentos e expressões quebram a métrica sem

\footnotetext{
${ }^{23}$ As discussões teóricas sobre métrica e ritmo continuaram tão detalhadas quanto antes, com nomes relevantes como J.P. Kirnberger (1721) e Carlo Gervasoni (1762). No universo lusobrasileiro, o principal tratado sobre as novas perspectivas do tratamento rítmico foi escrito por Francisco Ignácio Solano (1720-1800), Nova Instrucção Musical ou Theoria Prática da Música Rythmica (Lisboa, 1764).
} 
prescindir dela. De partida ele propõe um problema que, no nível superficial, sugere um troqueu na métrica binária (Fig. 14). No entanto, por se tratar de uma obra em uma métrica lenta (2/2), um dáctilo parece surgir na conjunção com uma circulatio no tenor e no alto, que, em terças paralelas, "impulsionam" as notas do acorde de $\mathrm{C}$ uma terça acima. Aliás, percebam que o dáctilo se forma na força do movimento consonante do terceiro tempo e dissonante no quarto. E o que afirma essa ideia é que, no compasso 3, o dáctilo é escrito sem o suporte da circulatio e através de um recurso motetístico tradicional, qual seja, repetir um motivo trocando as vozes, em pares.

Porém, como afirmamos acima, o compositor galante está num período de transição entre o uso rígido das métricas e sua expansão para um jogo rítmico mais individualizado, ou melhor, prosódico enquanto liberdade métrica. Assim, e um simples motete prova, os problemas métricos deste motete são mais intrincados do que pode vislumbrar nossa experiência empírica dos fatos.

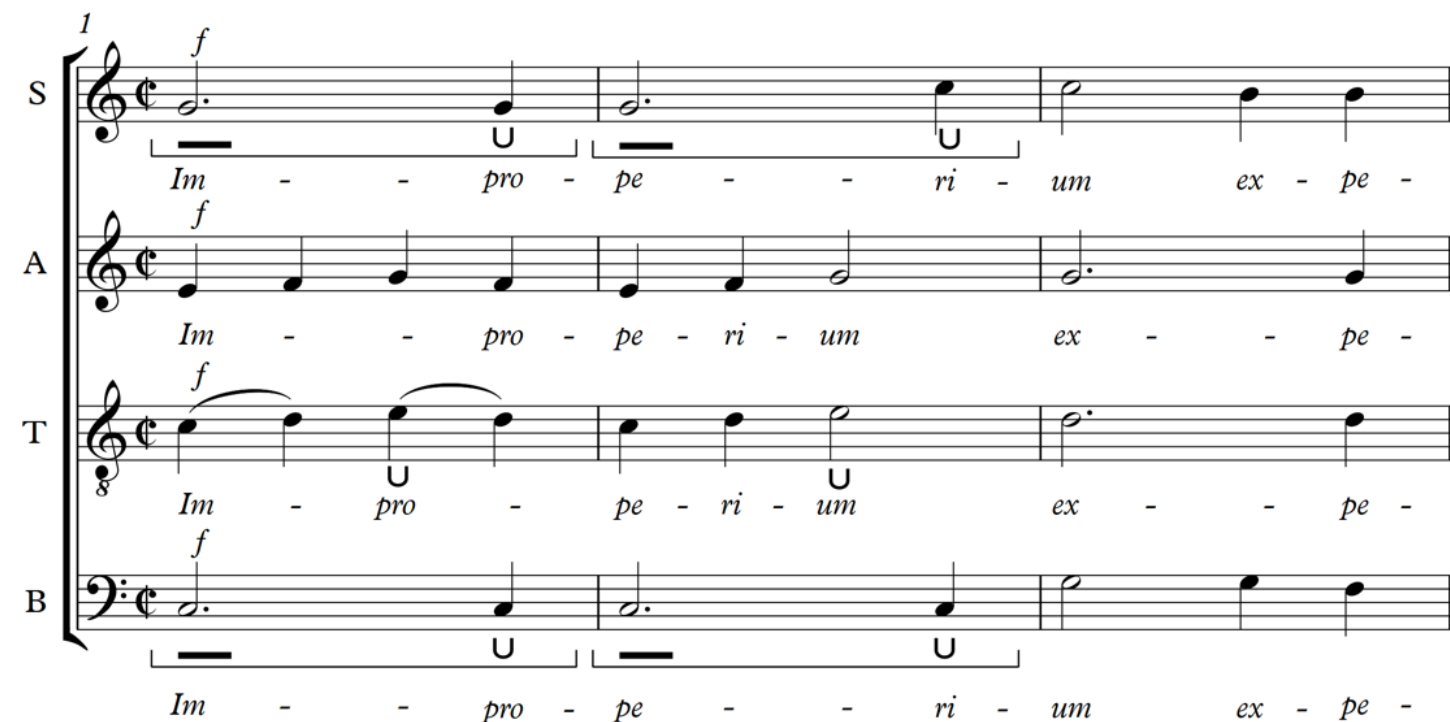

Figura 14: Nível básico da métrica do Improperium expectavit cor meum - compassos 1-2.

Observando toda a construção fraseológica podemos ver outras camadas do entrelaçamento da polifonia rítmica, assim como sua conjunção com a construção harmônica (Fig. 15). Ou seja, ao considerar a expansão da análise por toda a trama polifônica, a obra transluz. E o que vemos? A estrutura rítmica construída logo nos primeiros compassos da obra é feita sobre níveis 
É assim, porque é assim que tem que ser: a retórica galante nos motetes de José Maurício, observada no uso da pedagogia dos partimenti, da gramática das schemata e da oratória musical

arquitetônicos ${ }^{24}$ que se articulam para a emergência de um anfíbraco $(\cup ー \smile)$ como ritmo dominante.

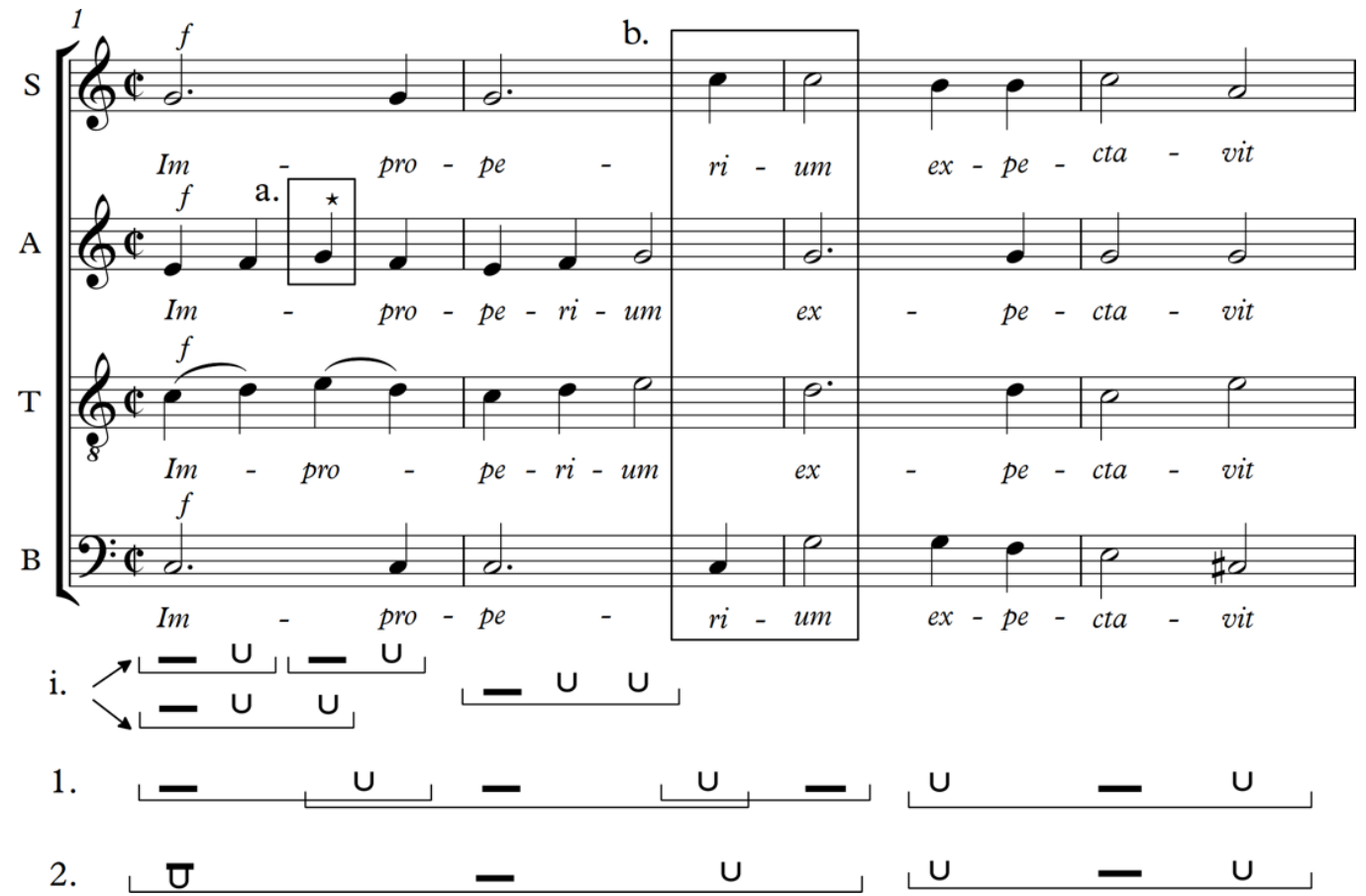

Figura 15: Análise das camadas da polifonia rítmica

E aqui algo que sempre deve chamar atenção quando lidamos com a mentalidade forjada sobre processos retóricos, ou seja, algo fora do comum. Explicamos, enquanto é comum em níveis primários e inferiores, o anfíbraco é pouco usual em níveis arquitetônicos superiores do ritmo. Por conta de seu caráter ambíguo, é preciso que os parâmetros que o formam em níveis menores sejam expostos de maneira que o acento funcione como uma espécie de pivô entre dois elementos não acentuados. (Cooper; Meyer 1960, p. 80).

Essa é uma estratégia comum para a música retoricamente pensada, mas difícil para nossa escuta. Por isso, vejamos em detalhes. Partindo do nível subprimário (i), logo no primeiro compasso há uma estrutura piramidal, i.e., onde dois padrões rítmicos acontecem ao mesmo tempo. Isto se dá devido ao fato de o Tenor iniciar a frase com a estrutura sub-primária bem evidente de um troqueu $(-\smile)$, enquanto no Alto o dáctilo $(-\smile \cup)$ se instaura. Este se fortalece na medida

\footnotetext{
${ }^{24}$ Como a harmonia e a melodia são organizadas arquitetonicamente (motivos, frases, períodos) assim é também o ritmo (Cooper; Meyer 1960, p.2). Seguindo o método de Grosvenor Cooper e Leonard Meyer, o ritmo é feito de níveis inferiores (ou sub-primário no caso de um único nível inferior), primário e superiores.
} 
MUSICA THEORICA Revista da Associação Brasileira de Teoria e Análise Musical 2020, v. 5, n. 2, p. 74-141 - Journal of the Brazilian Society for Music Theory and Analysis@ TeMA 2020 - ISSN 2525-5541

que é caracterizado pelo tempo fraco (a) em um andamento mais lento, o que o torna muito improvável de ser percebido como um batimento acentuado, mesmo se fosse um subgrupo.

Esta observação do nível sub-primário é importante, pois esta estrutura piramidal não pode ser reduzida a um único agrupamento rítmico de maneira arbitrária, já que o troqueu aparece de maneira estável, e o dáctilo, apesar de instável ainda neste momento, se estabelece definitivamente no compasso seguinte. Neste nível arquitetônico não há ambiguidade, mas essa proposital estrutura piramidal é o que ajudará a estabelecer o caráter ambíguo do anfíbraco nos níveis maiores.

Avançando para o nível primário (1), o troqueu inicial emerge por estar em seu ambiente mais propício - métrica binária,$-{ }^{25}$ mas seu tempo fraco já se estabelece como parte do agrupamento rítmico seguinte por aproximação melódica, harmônica e mesmo temporal. Ademais, o dáctilo do nível subprimário (i) no segundo compasso ajuda a conectar o tempo fraco com o agrupamento que já vem sendo formado no nível primário desde o tempo fraco do primeiro compasso; há, portanto, o estabelecimento do anfíbraco. Com a condução das vozes externas fazendo uma espécie de anacruse (b), o iâmbico ( $\smile-$ ) conclui esse momento com o anfíbraco como pivô. A característica que chama a atenção aqui é o caráter de prolongamento do compasso que o anfíbraco causa ao ultrapassar as barras de compasso e conectar os ritmos que o antecedem e que o procedem.

Com todos esses parâmetros colocados nos ritmos primário e subprimário, o ritmo do nível arquitetônico superior (2) que determinará o ritmo deste momento inicial surge com o anfíbraco, que por si só já possui um caráter ambíguo, uma vez que a tendência é, neste nível, ser percebido como subgrupos

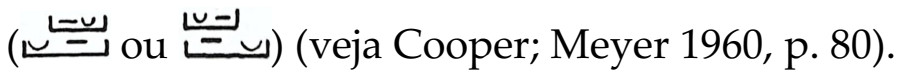

Em síntese, a ambiguidade ganha força no fato de o primeiro compasso se iniciar com uma estrutura piramidal no nível inferior e um troqueu no nível primário, o que causaria a percepção de um batimento acentuado no nível

\footnotetext{
${ }^{25}$ A mente humana tem a tendência de equalizar subgrupos ao nível do batimento da métrica (ex. uma mínima e duas semínimas serem entendidas como apenas dois momentos do ritmo), o que é chamado de Princípio da Equivalência Métrica (Cooper; Meyer 1960, p. 22). É devido a este princípio que ritmos de três tempos (anapesto e dáctilo) são menos encontrados em níveis primários de métricas binárias.
} 
superior de início, mas que é retrospectivamente entendido como um tempo fraco $(\bullet)$, já que em seguida o verdadeiro acento se estabelece, como dito antes, funcionando como pivô entre dois elementos não acentuados. Este pivô é feito exatamente através do anfíbraco no nível primário. Assim, também, a ambiguidade que se instaura logo nos primeiros três compassos é gradualmente dissolvida com o estabelecimento evidente do anfíbraco nos compassos seguintes (3 - 4 e 5 - 7).

\section{A oratória de José Maurício}

As seções anteriores trataram de analisar em separado cada parâmetro com a finalidade de demonstrar a sua organicidade e as estratégias do compositor para efetivar uma ideia, dentro de um ambiente forjado pelo pensamento retórico. Sobretudo, buscamos desvelar a disposição dos elementos expressivos da primeira parte da frase - improperium expctavit - como um pictorialismo consequente da ideia de ambiguidade afetiva dentro de um dos primeiros motetes para a Paixão de Cristo. Discutimos, também, como, desde o princípio, dogmas e/ou crenças e valores se apresentavam como uma situação dada que definiu as escolhas da unidade musical, ou seja, para a inventio. Especulamos, inclusive, haver uma perspectiva de devir por uma solução de continuidade do motete para dentro da cerimônia, ou seja, sua composição seria pensada como um ciclo musical ou mesmo para um agenciamento virtual de largo alcance.

E quais foram as estratégias de José Maurício para construir um discurso que ao mesmo tempo fosse interpretável à luz da retórica e, consequentemente, do decoro de seu tempo?

1. Uma tonalidade que desde o princípio é instável, mesmo considerando uma tonicização branda de $C$ para $G$, o que pode sugerir uma ideia de mudança, mas não brusca.

2. Esquemas de contraponto que "desenhavam" uma metáfora de transição.

3. Uma métrica escrita para não se fixar num padrão único, ou melhor, trabalhando um padrão de natureza ambígua.

Porém, como todos esses elementos separados constituem uma estratégia de oratória? 
MUSICA THEORICA Revista da Associação Brasileira de Teoria e Análise Musical 2020, v. 5, n. 2, p. 74-141 - Journal of the Brazilian Society for Music Theory and Analysis @ TeMA 2020 - ISSN 2525-5541

Acreditamos que a primeira metáfora apresentada diz respeito a um destino. A rápida mudança tonal ou uma marcação métrica com um dáctilo sobre uma mesma nota seria facilmente compreensível numa perspectiva de destino fatal, para ouvidos habituados a essas construções pictóricas. A questão da ambiguidade seria uma propriedade associativa, a partir do primeiro impulso. Ou seja, pressupunha-se que o ouvinte atento deveria perceber outros elementos somados ao dáctilo, como a presença de uma circulatio intensificando a tensão e, principalmente, uma ucita di tono dando a uma tonicização tênue uma "tinta" de apreensão, como que dizendo "deste ponto, a mudança ocorre". Aliás, essa pequena inflexão, típica de uma ombra, se projeta como trabalho argumentativo do compasso 8 em diante. Neste espaço, as tonicizações se tornaram rápidas e com o uso do recurso cromático, como no compasso 4.

A partir dessa síntese, podemos supor que José Maurício parece recorrer à tradição do simbolismo musical para compor seu discurso. Isso porque, combinando a métrica, o uso dos movimentos harmônicos (das tonicizações aos esquemas de contraponto), e, inclusive, questões pontuais, como o caso da ucita di tono, vemos uma construção recorrente de semânticas para destinos incontornáveis. No entanto, o que é interessante notar é a recorrência de ambiguidades. É como se, pela música, José Maurício quisesse discutir os dogmas de Cristo, considerando seu inevitável destino: humano e divino, suscetível à paixão humana, mas crente de sua missão salvífica.

Neste sentido, e consequente com a análise das relações dos recursos retóricos (tons, esquemas, métricas e figuras), há um detalhe que provavelmente está sustentado em suas doutrinas religiosas. Este se desvela quando interpretado à luz do "que não está no lugar": o modo maior da tonalidade. Ora, para um ambiente que deveria ser disfórico, como o caso da consciência de Cristo diante do seu destino, o modo maior marca todo o ambiente. Isto porque, este modo maior nos induz interpretar que a leitura de José Maurício desse trecho bíblico é que o destino, nesse momento dolorido, não é um fato negativo.

Esse é um detalhe importante que uma análise das mentalidades ajuda a compreender. Em termos gerais, ou seja, o que José Maurício compartilha esteticamente com seus contemporâneos é uma estética comum na música galante: a estética do devir. Neste motete, o devir está na recusa de sublinhar a dor do momento, ou seja, a constatação de Cristo dos impropérios que lhe infligem. Aliás, diga-se, o devir que trabalha José Maurício não é resolvido na música, mas 
É assim, porque é assim que tem que ser: a retórica galante nos motetes de José Maurício, observada no uso da pedagogia dos partimenti, da gramática das schemata e da oratória musical

sim sobre o agenciamento que ocorre no compartilhamento comunitário da história bíblica. Em outras palavras, José Maurício trabalha uma estratégia apostando num agenciamento virtual sobre a relação dogmática da Paixão: a redenção. Sem a certeza de que seu ouvinte compreenderia isso na escolha por uma tonalidade maior, sua música poderia causar um estranhamento afetivo no campo do decoro.

No entanto, a questão do decoro é complexa na medida que temos que entender o que valida um modo maior no momento de uma aflição. Para resolver essa questão devemos recorrer a uma ampliação do que consideramos ser uma recorrência simbólica na música de José Maurício.

Inúmeros exemplos vistos no conjunto de sua obra nos permitem afirmar que o mestre carioca desenvolve a representação da morte numa perspectiva, religiosa e positiva, da redenção. Em muitas passagens disfóricas, como em mementos, José Maurício atenua o caráter grave da morte usando contrastes tópicos ou tonais, como acordes maiores em trechos menores, ou mesmo passagens pastorais. Julgamos ser esta uma manifestação de sua crença mariana, como já tratamos em outros textos. ${ }^{26}$

Dito isso, é relevante que esse problema surja, musicalmente, num solilóquio do Domingo de Ramos, e logo nos primeiros compassos. Isso, com certeza, indica diversas indexações, inclusive a clausula que tratamos acima, no sentido de uma morte mediada pela Igreja. Em outras palavras, a rede de significações se sustenta na ideia da Paixão como uma morte para a redenção e cujo único mediador é a religião.

Por isso, logo nos primeiros compassos José Maurício estabelece um relacionamento de ambiguidade de dois espaços tonais conjugados, C e G. Interpretamos isso como estratégia para um motete que, num ambiente eufórico do Domingo de Ramos, guardava a certeza de um destino marcado pela Crucificação.

Assim, essa movimentação entre propriedades muito próximas revelaria, por um lado, uma modulação do sentimento dentro de um solilóquio, sem contrastar seu afeto a ponto de projetar uma negação de um compromisso, no caso vinda de uma tomada de consciência de Cristo de seu destino. No entanto,

\footnotetext{
${ }^{26}$ Cf. Machado Neto, Diósnio, E jazerá em jardim florido: estudo preliminar sobre usos tópicos na representação da Mariologia na música de José Maurício Nunes Garcia (2019).
} 
MUSICA THEORICA Revista da Associação Brasileira de Teoria e Análise Musical 2020, v. 5, n. 2, p. 74-141 - Journal of the Brazilian Society for Music Theory and Analysis @ TeMA 2020 - ISSN 2525-5541

a música mostra-se instável desde um primeiro momento. Instabilidade que se afirma a partir do compasso 8, com uma progressão harmônica estabelecida numa sequência de cromatismos, mas que alcança seu auge, e simbolismo, na cadência final: a escolha de uma clausula vera incompleta invertida e sua continuidade com a recitação da missa.

Neste ponto podemos observar dois elementos eloquentes dos usos e estratégias de José Maurício: simbolicamente, a clausula dá uma forte identidade religiosa ao trecho como afirmando sua "posse" para desvelar os dogmas da Paixão e, sonoramente, uma ruptura da própria recitação da missa que, de certo modo, inicia um período que adensará o aspecto trágico e ao mesmo tempo redentor da Semana Santa.

Assim, justifica-se o fato de que, apesar de o modo maior não ser contrastado, ele também não mantém a sua propriedade. Na verdade, a sutileza no tratamento das propriedades hexacordais respondem a uma estratégia de contraste tênue que projeta muito mais do que aparenta. É um contexto expressivo para a ambiguidade e para o devir. Inclusive, poderíamos ir além nas interpretações simbólicas das tonalidades e suas relações indexais com toda a Paixão. Por exemplo, a rápida transição ao G Bquadrado de certo modo vai acomodando lentamente uma sonoridade que, em um modo menor, simbolizaria sobejamente os momentos de morte. Portanto, há uma ideia, pois o movimento abre uma possibilidade de imaginar que esse Sol maior, opondo-se a Dó maior (uma tonalidade de "coroação"), estaria disposto como uma tonalidade que guardava um destino, o da morte, mas uma morte para o Reino dos Céus, radicionalmente escrito em tonalidades de Sol menor. E isso é significativo em termos de afeto, pois justificaria a funcionalidade dessa tonicização precoce, e “adornada com um cromatismo" e, também, (a presença do dáctilo na nota Sol, um forte símbolo das tragédias. Mas está em modo maior.

Logo, nos parece claro que, ao escrever a música sobre o texto Improperium expectavit cor meum ("meu coração esperava reprovação"), José Maurício buscou, no mínimo, ressaltar que algo muda quando Jesus admite que "esperava reprovação". Mudança que está nas escolhas - feitas no nível da inventio reveladas desde o menor elemento da gramática musical.

Em síntese, todas as escolhas de José Maurício estão pensadas numa expectativa da Paixão. O compositor, perito por vocação na arte sacra, cria agenciamentos apoiado na correlação de sentidos que sabe encontrar na sua 
É assim, porque é assim que tem que ser: a retórica galante nos motetes de José Maurício, observada no uso da pedagogia dos partimenti, da gramática das schemata e da oratória musical

audiência. É por isso que vemos sutilezas como a escolha da tonalidade maior; o caminho harmônico tratando de trabalhar sobre as propriedades hexacordais e, também, as tonicizações; as características dos esquemas de contraponto (é muito interessante o uso de esquemas de transição); as métricas, como o dáctilo em face do anfíbraco e, por fim, as figuras de linguagem (a circulatio é fundamental para a construção do caráter da ambiguidade).

Por fim, não há como negar a dimensão de seu discurso, inclusive numa perspectiva ideológica: o da crença na redenção. Construindo sob uma base de ambiguidades tonais e métricas, José Maurício com muita sutileza escreve um motete que parece revelar a essência da Paixão de Cristo. E ela estaria em algo simples: em modo maior que, mesmo considerando certas agitações, mantem-se sereno.

E esta análise reforça uma ideia que vimos construindo no trato de sua obra: José Maurício é um compositor de filigranas.

\section{Conclusão}

Através de um pequeno motete de José Maurício, escrito para o Domingo de Ramos, tratamos de mostrar algumas características de escrita que revelam mais do que a perícia de um compositor específico, revelam elementos que nos permitem associá-lo a questões paradigmáticas do seu tempo, não só em relação a formação de sua perícia, mas também de suas plataformas ideológicas de discurso.

E quais perícias a análise destes trechos nos permitem afirmar?

1. Que é uma perícia que se sustenta sobre pleno domínio dos ensinamentos realizado pelos partimenti. Isso pode ser visto pelas harmonias construídas sobre a Regra da Oitava, inclusive por alguns derivativos, como a "regra do mi";

2. Domínio de ferramentas retóricas que são articuladas no bojo dos partimenti, como as schemata. É de se sublinhar alguns domínios de certas funções sintáticas desse parâmetro, como tratamos de mostrar no caso no uso dos esquemas de "transição";

3. Em termos retóricos gerais, aqueles que se desdobram não apenas do treinamento pelos partimenti em si, mas das ferramentas ensinada nos sofeggios (como o uso de figuras) e, também, pela faculdade da retórica 
(como as métricas), José Maurício igualmente revela plena ciência, inclusive de uma tradição secular de uso de um capital simbólico;

4. Concepção de música como discurso, usando sempre as regras da oratória musical de seu tempo (o uso de pictorialismo ao invés de tópicas para o motete é saliente para vermos esse problema). No caso. José Maurício usa inúmeros recursos retóricos para expor questões dogmáticos da Paixão de Cristo

Em síntese, tratamos de demonstrar como a mentalidade galante se projeta através de um acervo retórico na exposição de valores e crenças - que chamamos ideologia - através de usos de elementos em combinatória; inclusive com elementos que podemos considerar idiossincráticos. Fizemos essa exposição a partir da ideia musical que, para José Maurício, chamamos de redenção. Especificamente, começamos pela base epistemológica do seu saber musical. Expusemos elementos que nos permitem relacionar usos de uma gramática musical associada, antes de mais nada, a paradigmas cujos fundamentos nos permitem especular pela adesão a um modelo retórico localizado no tempo. Sublinhamos que alguns usos, como o tratamento de dissonâncias ou até mesmo os das "notas mi", estão sob a égide de uma marca: a escola durantisti de Fenaroli. Isso restringe as "atualizações" harmônicas de José Maurício para o tempo de vigência destes conceitos, ou seja, do último quartel do século XVIII; considerando que a formação de José Maurício se deu na década em meados da década de 1770, é um sincronismo importante. Acreditamos ter exposto, também, que já num motete de 1799 José Maurício dominava a sutileza de determinados esquemas de contraponto. Neste ponto, tratamos de mostrar um caso sobre o uso de esquemas de transição que, dos cadernos de Rippel, se espraiam na música galante da segunda metade do século XVIII. Evidentemente, podemos concluir que a perícia de José Maurício reconheceria outros esquemas, como de fato reconhece, como já mostramos em outros artigos.

Por fim, quisemos debater como esse conjunto articulado, trabalhado numa concepção retórica absolutamente sincronizada em seus conteúdos com os mestres europeus, definem questões locais. Primeiro naquilo que dita o decoro. Como afirmamos, José Maurício assume de tal forma o caráter da dignidade do ato, uma música para a Semana Santa, que não a escreve fora de um estilo eclesiástico rígido, a ponto de não usar campos tópicos como elementos de contraste. Restringe sua escrita a pictorialismos construídos sobre métricas, 
É assim, porque é assim que tem que ser: a retórica galante nos motetes de José Maurício, observada no uso da pedagogia dos partimenti, da gramática das schemata e da oratória musical

harmonias (inclusive explorando questões afetivas das tonalidades, como vimos no uso de uma mudança) e figuras de retórica.

Segundo, seus argumentos são construídos sob uma base discursiva que confirma uma ideia presente em muitas outras obras: o caráter purificador da morte em Cristo. Nesse motete, em específico, vimos isso na escolha da tonalidade (inclusive na mudança) e como ela se projeta sobre um texto que, em sua natureza, deveria estar associada a uma música disfórica. Mais que isso, numa combinatória sutil tece vários elementos retóricos para mitigar um caráter que, por exemplo, na Paixão segundo São João de Bach é retratada numa música exacerbada em severa aspereza, como metaforizando uma dor física de Jesus. Podemos afirmar, hoje, que a visão de José Maurício da morte religiosa é sublime. E esse motete alimenta nossa tese.

Enfim, o espaço e alcance da ars rhetorica tece uma teia de vínculos culturais profundos e necessita sempre uma prospecção das referências vigentes na sociedade que a opera; estamos sempre diante de um desafio antropológico cultural. Aliás, a ideia de que essa música transcende seu tempo é relativa, e hoje cobra seu preço nos modelos de análise e interpretação pela distância que temos de suas estruturas epistemológicas. Cabe dizer que esta ideia de uma "grande arte que está além de seu tempo" está mais associada ao que é nosso do que ao que é dela. No jogo de força para definir como entendemos essa música estão diversos aspectos sociopolíticos e culturais de grande escala, da Revolução Francesa até cientificismo do século XIX; do Modernismo até as estratégias de mercado da sociedade de massa. Tais forças fazem com que assumamos uma "tradição" enviesada, para não dizer inventada, como a da teoria musical fincada na funcionalidade orgânica dos parâmetros musicais em detrimento do que esta música nos permite como fruto de processos sociocomunicacionais de lastros profundos. E nestes vórtices de múltiplos sentidos existiu todo um esforço de patrimonializar essa música, agora "Clássica", para promover uma melhor inteligência, uma inteligência da "grande tradição ocidental". Este não era um caminho qualquer, pois servia, e serve, para uma ação colonizadora ocidental; descobriu-se que a colonização se dá principalmente nos afetos e subjetividades das pessoas. E, se isso era inerente do espírito imperialista novecentista, o Século XX veio no fluxo, até inconscientemente, para intensificar o deslocamento de sentido da música, fosse galante ou tradicional dos povos originais, para nossas 
MUSICA THEORICA Revista da Associação Brasileira de Teoria e Análise Musical 2020, v. 5, n. 2, p. 74-141 - Journal of the Brazilian Society for Music Theory and Analysis@ TeMA 2020 - ISSN 2525-5541

necessidades culturais e comerciais, como gosto, fetiche ou mesmo uma simples marca de distinção social.

Por fim, o primeiro a se concluir é que acreditamos que é necessário ampliar nossa visão sobre os usos gramaticais e retóricos de compositores de nosso passado colonial para que possamos não só ter mais alcance de algo que é obvio, mas não é tão palpável - a circulação dos saberes no espaço lusobrasileiro - mas, e principalmente, inserir uma história da recepção da teoria musical nas plataformas de investigação de uma história das mentalidades. Somente assim daremos um salto de algo já consolidado na nossa musicologia - a documentação de nossa história musical, inclusive do acervo de partituras - para algo que a impulsionará para um outro patamar que pode ser resumido simplesmente assim: qual a genética conceitual (como capital simbólico e bases teóricas), e para quais discursos, a música no Brasil colonial esteve associada?

Como uma conclusão geral, vemos que temos um problema epistemológico de amplo alcance quando tratamos de música que, de certo modo, é marcada por deslocamentos. No caso da música galante, não há como desconsiderar o espaço e alcance da Retórica. É por ela que compositores teciam uma teia de vínculos culturais profundos que necessita, hoje, uma prospecção das referências vigentes na sociedade que a opera; estamos sempre diante de um desafio antropológico cultural. Aliás, a ideia de que essa música transcende seu tempo é relativa, e hoje cobra seu preço nos modelos de análise e interpretação pela distância que temos de suas estruturas epistemológicas. Cabe a nós uma justiça a ela.

\section{Bibliografia}

1. Allanbrook, Wye J. 1983. Rhythmic Gesture in Mozart. London: The University of Chicago Press.

2. Bimbato, Ozório; Machado Neto, Diósnio. 2013. Nápoles, Lisboa e São Paulo: a tradição dos partimenti no século XVIII. In: Anais XXIII Congresso da Associação Nacional de Pesquisa e Pós-Graduação em Música. Natal: ANPPOM. Disponível em <file:///Users/dmneto/Downloads/2469-6996-1-PB.pdf>

3. Bonds, Mark Evan. 1991. Wordless Rhetoric: musical form and the metaphor of the oration. Cambridge: Harvard University Press. 

motetes de José Maurício, observada no uso da pedagogia dos partimenti, da gramática das schemata e da oratória musical

4. Byros, Vasili. 2014. Topics and Harmonic Schemata: A Case from Beethoven. In: Mirka, Danuta (ed.), The Oxford Handbook of Topic Theory. New York: Oxford University Press, p. 381-414.

5. Cafiero, Rosa. 1993. La didattica del partimento a Napoli fra Settecento e Ottocento: Note sulla fortuna delle Regole di Carlo Cotumacci. In: Maria Caraci, Rosa Cafiero, and Angela Romagnoli (eds.), Gli affetti convenient alVidee: Studi sulla musica vocale italiana. Naples: Edizioni Scientifiche Italiane, p. 549-580.

6. _ _ 2007. The Early Reception of Neapolitan Partimento Theory in France: A Survey. Journal Of Music Theory, Durham, v. 51, n. 1, p. 137-159.

7. Caplin, William. 2008. Theories of musical rhythm in the eighteenth and nineteenth centuries In: Christensen, T. (Ed.). The Cambridge History of Western Music Theory. Cambridge: Cambridge University Press.

8. Castilho, Maria Luisa. 2009. As obras de Manuel de Tavares e o desenvolvimento da policoralidade na polifonia portuguesa do século XVII. 2009. Tese (Doutorado em Música e Musicologia) - Universidade de Évora, Évora.

9. Christensen, Thomas. 1992. "The 'Règle De L'Octave' in thorough-bass theory and practice." Acta Musicologica, vol. 64, no. 2, 1992, pp. 91-117.

10. _ 2010. Thoroughbass as music thoery. In: Christensen, Thomas et al. Partimento and continuo playing: In theory and in practice. Leuven: Leuven University Press, p. 9-41.

11. Christovam, Ozório. 2018. Música Sacra, Discurso e Poder: Modelos PréComposicionais na Missa Luso-Brasileira. Tese (Doutorado em Musicologia). São Paulo: ECA-USP.

12. Christovam, Ozório; Machado Neto, Diósnio. 2019. Estratégias comunicativas na música sacra de André da Silva Gomes: retórica, tópicas, partimento e esquemas musicais. In: PÁSCOA, Marcio et all. Música em Diálogo> Manaus: Editora da Universidade do Amazonas, pp. 11-22.

13. Coelho Machado, Raphael. 1842. Signos do Diccionario Musical. Rio de Janeiro: B.L.Garnier.

14. Cooper, Grosvenor; Meyer, Leonard. 1960. The Rhythmic Structure of Music. London: The University of Chicago Press.

15. Crespo, Sílvio. 1990. O Hino a 4 de Marcos Coelho Neto. Revista Música, v. 1, n. 2, p. 69-78. 
MUSICA THEORICA Revista da Associação Brasileira de Teoria e Análise Musical 2020, v. 5, n. 2, p. 74-141 - Journal of the Brazilian Society for Music Theory and Analysis @ TeMA 2020 - ISSN 2525-5541

16. Decker, Gregory J. 2020. Dance Music and Signification in Handel's Opera Seria. In: Decker, G. \& Shaftel, Matthew (Ed.). Singing in Signs; New Semiotic Exploration of Opera. New York: Oxford University Press.

17. Dottori, Maurício. 1990. A Estrutura Tonal na Música de João de Deus de Castro Lobo. Cadernos de Estudo: Análise Musical, v. 3, p. 44-51.

18. __ 1992. Ut Rhetorica Musica: análise do moteto O Vos Omnes a dois coros, de Manoel Dias de Oliveira. Revista Música, v. 3, n. 1, p. 53-69.

19. Duprat, Régis. 1990. Música Sacra Paulista no Período Colonial: alguns aspectos de sua evolução tonal - 1774/1794. Revista Música, v. 1, n. 1, p. 29-34.

20. Duprat, Régis et al. 1998. A "Arte Explicada de Contraponto" de André da Silva Gomes. São Paulo: Arte e Ciência.

21. Fenaroli, Fedele. 1775. Regole Musicali Por Principianti Di Cembalo. Editado por Robert O. Gjerdingen. Disponível em http://facultyweb.at.northwestern.edu/music/gjerdingen/Partimenti/collections/Fenaroli/r egole/index. Acesso em: 01 maio 2020.

22. Fernandes, Cristina. 2013. "Boa voz de tiple, sciencia de música e prendas de acompanhamento": O Real Seminário da Patriarcal, 1713-1834. Lisboa: Biblioteca Nacional de Portugal.

23. Furno, Giovanni. 1817. Metodo Facile breve e chiaro delle prime ed essensiali regole per accompagnare Partimenti senza numeri del Maestro Giovanni Furno. Editado por Robert O. Gjerdingen. Disponível em: https://web.archive.org/web/20160410072202/http://facultyweb.at.northwestern.edu/music/gjerdingen/partimenti/collections/Furno/in dex.htm. Acesso em: 01 maio 2020.

24. Gjerdingen, Robert O. 2007. Music in the galant style. New York: Oxford University Press, Inc.

25. _. 2020. Child Composers in the Old Conservatories: how orphans became elite musicians. Nova Iorque: Oxford University Press.

26. Hartmann, Ernesto. 2018. A Sinfonia Fúnebre (1790) do Padre José Maurício Nunes Garcia (1767-1830): análise com o conceito de Schema Musical de Robert Gjerdingen. Mirabilia, n. 27, p. 221-253.

27. _ _ 2019. O uso da Schemata na construção da Abertura Zemira (1803) do Padre José Maurício Nunes Garcia. Revista Vórtex, v. 7, n. 1, p. 1-36.

28. Kater, Carlos. 1994. Análise e Música Brasileira dos séculos XVIII e XIX. Cadernos de Estudo: Análise Musical, n. 6/7, p. 104-118. 

motetes de José Maurício, observada no uso da pedagogia dos partimenti, da gramática das schemata e da oratória musical

29. Hatten, Robert S. 1994. Musical Meaning in Beethoven: markedness, correlation, and interpretation advances in semiotics. Indiana: Indiana University Press.

30. Ijzerman, Job. 2018. Harmony, Counterpoint, Partimento: a new method inspired by old masters. Nova Iorque: Oxford University Press.

31. Machado Neto, Diósnio. 2017. A arte do bem morrer: O discurso tópico na Sinfonia Fúnebre de José Maurício Nunes Garcia. Revista Portuguesa de Musicologia, v. 4, n. 1, p. 33-66.

32. __ 2019. E jazerá em jardim florido: estudo preliminar sobre usos tópicos na representação da Mariologia na música de José Maurício Nunes Garcia. Per Musi, v. 39, p. 1-28.

33. Mirka, Danuta. Introduction. 2014. In: Mirka, Danuta (ed.), The Oxford Handbook of Topic Theory. Oxford: Oxford University Press.

34. Monteiro, Guilherme. 2020. Análise Tópica de Schemata e Elementos RetóricoMusicais em Seis Responsórios Fúnebres de João de Deus de Castro Lobo (17941832). Dissertação (Mestrado em Letras e Artes). Manaus: Universidade Estadual do Amazonas.

35. Neuwirth, Markus; Bergé, Pieter. (ED.) 2015. What is a Cadence? Theoretical and Analytical Perspectives on Cadences in the Classical Repertoire. Louvain: Leuven University Press, 2015.

36. Páscoa, Márcio. O quanto é preciosa ao Compositor a Instrução Literária?: o projeto criativo em Arte explicada do contraponto de André da Silva Gomes (1752-1844). Revista Orfeu, v. 5, n. 3, p. 146-163.

37. Ramos, Rafael Registro. 2011. Discurso e Conceitos no Tratado de Contraponto de André da Silva Gomes: Um Estudo de Recepção. Dissertação (Mestrado em Musicologia). São Paulo: ECA-USP.

38. Ratner, Leonard G. 1980. Classic Music: Expression, Form, and Style. New York: Macmillan Publishing Co. Inc.

39. Rumph, Stephen. 2012. Mozart and Enlightenment Semiotics. Berkeley: University of California Press.

40. Sánchez-Kisielewska, Olga. 2016. Interactions between Topics and Schemata: The Case of the Sacred Romanesca. Theory and Practice, v. 41, p. 47-80.

41. Sanguinetti, Giorgio. 1997. Un secolo di teoria della musica in Italia: Bibliografica critica 1850-1950. Fonti musicali italiane: Periodico di ricerca musicologica, 2, p. 155-248 
MUSICA THEORICA Revista da Associação Brasileira de Teoria e Análise Musical 2020, v. 5, n. 2, p. 74-141 - Journal of the Brazilian Society for Music Theory and Analysis @ TeMA 2020 - ISSN 2525-5541

42. _. 2007. The realization of partimenti: An introduction. Journal of Music Theory, v. 51, n. 1, p. 51-83.

43. _ . 2012. The art of partimento: History, theory, and practice. New York: Oxford University Press, Inc..

44. Trilha Neto, Mário Marques. 2011. Teoria e prática do baixo contínuo em Portugal. 410 f. Tese (Doutorado) - Curso de Música, Departamento de Comunicação e Arte, Universidade de Aveiro, Aveiro, 2011.

45. Van Tour, Peter. 2015. Counterpoint and Partimento: Methods of Teaching Composition in Late Eighteenth-Century Naples. Uppsala: Uppsala Universitet.

46. Yozhiyoka Almeida, Ágata; Machado Neto, Diósnio. 2020. Interação entre tópicas musicais e o esquema harmônico le-sol-fi-sol na Missa de Réquiem (1816) de Marcos Portugal. Revista Música Hodie, v. 20. 